UNIVERSIDADE DE SÃO PAULO

FACULDADE DE FILOSOFIA, CIÊNCIAS E LETRAS DE RIBEIRÃO PRETO DEPARTAMENTO DE PSICOLOGIA E EDUCAÇÃO PROGRAMA DE PÓS-GRADUAÇÃO EM PSICOBIOLOGIA

\title{
DISCRIMINAÇÕES SIMPLES E COMPLEXAS EM RATOS: \\ EFEITOS DA DESNUTRIÇÃO PROTÉICA E DA ESTIMULAÇÃO
}

ELIMAR ADRIANA DE OLIVEIRA FELICIANO

Tese apresentada à Faculdade de Filosofia, Ciências e Letras de Ribeirão Preto - USP, como parte das exigências para obtenção do título de doutor em Ciências. Área de Psicobiologia

Ribeirão Preto - SP 
UNIVERSIDADE DE SÃO PAULO

FACULDADE DE FILOSOFIA, CIÊNCIAS E LETRAS DE RIBEIRÃO PRETO DEPARTAMENTO DE PSICOLOGIA E EDUCAÇÃO PROGRAMA DE PÓS-GRADUAÇÃO EM PSICOBIOLOGIA

\section{DISCRIMINAÇÕES SIMPLES E COMPLEXAS EM RATOS: \\ EFEITOS DA DESNUTRIÇÃO PROTÉICA E DA ESTIMULAÇÃO}

ELIMAR ADRIANA DE OLIVEIRA FELICIANO

Tese apresentada à Faculdade de Filosofia, Ciências e Letras de Ribeirão Preto - USP, como parte das exigências para obtenção do título de doutor em Ciências. Área de Psicobiologia

Orientador: Prof. Dr. Luiz Marcellino de Oliveira

Ribeirão Preto - SP 
Feliciano, Elimar Adriana de Oliveira.

Discriminações simples e complexas em ratos: efeitos da desnutrição protéica e da estimulação. Ribeirão Preto, 2006.

$$
101 \text { p. : il. ; } 30 \mathrm{~cm}
$$

Tese de Doutorado apresentada à Faculdade de Filosofia, Ciências e Letras de Ribeirão Preto/USP. Área de concentração: Psicobiologia

Orientador: De Oliveira, Luiz Marcellino.

1. Ratos 2. Desnutrição protéica 3. Estimulação

4. Discriminação Simples 5. Discriminação complexa 


\section{DEDICATÓRIA}

A Giovana (Gi) e Leonardo (Léo), meus queridos filhos, com amor e carinho. 


\section{AGRADECIMENTOS}

Ao Prof. Dr. Luiz Marcellino de Oliveira, que nos anos de convivência, muito me ensinou, contribuindo para meu crescimento científico e intelectual.

À Prof. Dra. Deisy das Graças de Souza, pela imprescindível colaboração durante a elaboração do procedimento de discriminação condicional.

Ao Prof. Dr. Sebastião de Sousa Almeida, pela orientação e auxílio na análise estatística e, principalmente, pela amizade.

Ao meu marido Agnaldo, pelo constante apoio e incentivo durante a execução desse trabalho.

Ao meu pai, a minha mãe e ao meu irmão, que durante toda a minha vida me deram educação, apoio e incentivo.

Ao técnico Eldereis de Paula, pela execução dos programas utilizados nesse estudo e pelo apoio na elaboração de relatórios de dados.

Ao técnico Dalmo Nicola, pelos vários auxílios durante a execução desse trabalho e, sobretudo pela amizade.

Ao técnico João Luis Segala Borin, pelos auxílios na impressão dos vários relatórios e da tese.

Às secretárias Renata, Inês e Denise pela atenção que sempre me dispensaram. 
Às bibliotecárias da Universidade de São Paulo, Ribeirão Preto, pelas correções das referências de acordo com as normas da Associação Brasileira de Normas Técnicas (ABNT).

A todos os colegas do laboratório de Nutrição, Comportamento e Desenvolvimento que ansiaram pelo fim desse trabalho e, sobretudo, pela amizade.

À Fundação de Amparo à Pesquisa do Estado de São Paulo (FAPESP) pela concessão da bolsa de doutorado e pelo apoio financeiro para a realização desta pesquisa.

E, especialmente a DEUS, por me dar sabedoria e coragem. 
“Se um homem tem um talento e não tem capacidade de usá-lo, ele fracassou. Se ele tem um talento e usa somente a metade deste, ele fracassou parcialmente. Se ele tem um talento e de certa forma aprende a usá-lo em sua totalidade, ele triunfou gloriosamente e obteve uma satisfação e um triunfo que poucos homens conhecerão”.

Thomas Wolfe 


\section{SUMÁRIO}

\section{RESUMO}

\section{ABSTRACT}

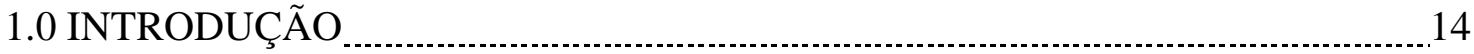

2.0 OBJETIVOS

3.0 MÉTODO

3.1. Sujeitos $\quad 30$

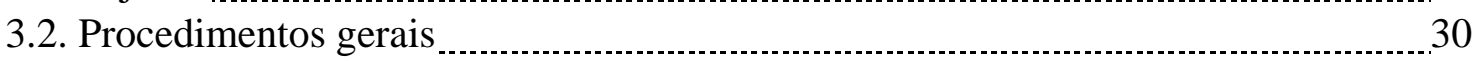

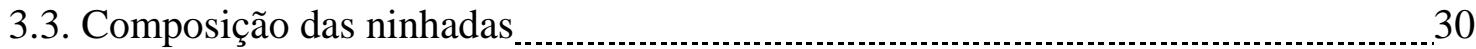

3.4. Alojamento dos animais $\ldots$

3.5. Condições ambientais do biotério

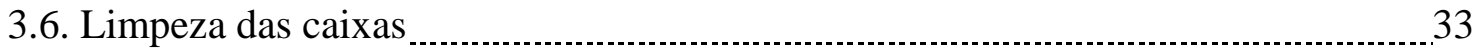

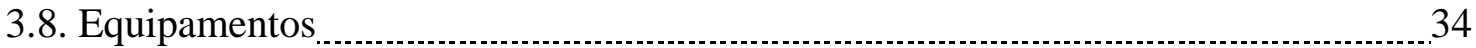

3.9. Procedimento do treino da discriminação

3.10. Reversão da discriminação de som ou luz _.................................................. 36

3.11. Experimento 2- Discriminação complexa

3.12 Sujeitos $\ldots \ldots \ldots$

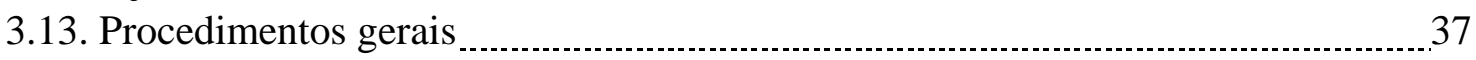

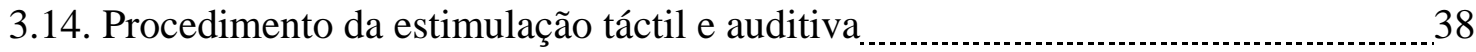

3.15. Equipamentos 39

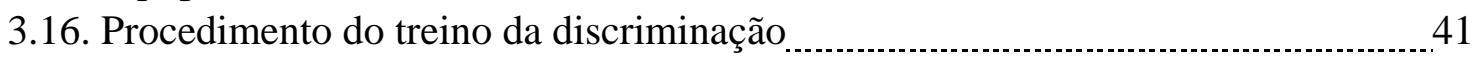

3.17 Reversão da discriminação

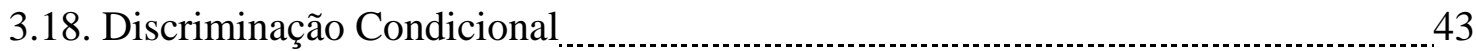

3.19. Análise estatística dos dados

4.0. RESULTADOS

4.1.Pesos corporais $\quad 46$

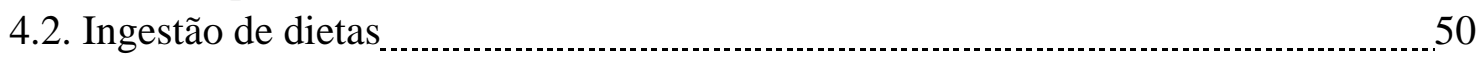

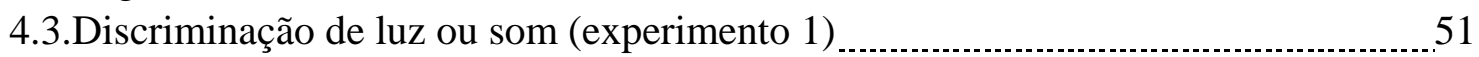

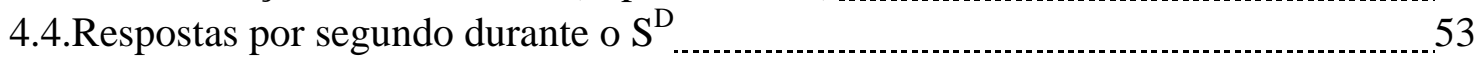

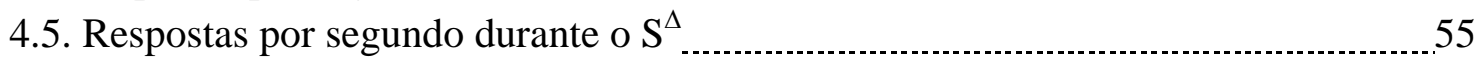

4.6. Experimento $2 \ldots$

4.7. Pesos corporais $\ldots \ldots \ldots$

4.8. Ingestão de dieta na lactação

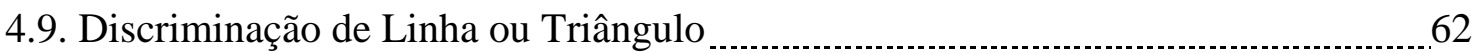

4.10. Reversão da discriminação $\ldots \ldots \ldots$

4.11. Discriminação condicional

5.0 . DISCUSSÃO

6.0.CONCLUSÕES

7.0 ANEXO

8.0. REFERÊNCIAS 
RESUMO 


\section{RESUMO}

FELICIANO, E. A. DE OLIVEIRA. Discriminações simples e complexas: efeitos da desnutrição protéica e da estimulação Tese (Doutorado) - Faculdade de Filosofia, Ciências e Letras de Ribeirão Preto, Universidade de São Paulo, Ribeirão Preto, 2006.

Uma deficiência nutricional no início da vida resulta em alterações morfológicas, bioquímicas e comportamentais. As conseqüências da desnutrição para o comportamento podem ser alteradas pelas condições ambientais. O objetivo do experimento 1 foi analisar os efeitos da desnutrição em procedimentos de discriminações simples e do experimento 2 os efeitos da desnutrição e da estimulação (handling e auditiva) em discriminações simples e complexas. Em ambos os experimentos, as dietas de $16 \%$ (Controles - C) ou 6\% de proteína (Desnutridos - D) foram oferecidas aos ratos do nascimento até 35 dias de idade. Dos 35 dias de idade até o final dos experimentos foram oferecidas dietas comerciais. Antes dos 85 dias de idade, os pesos corporais dos ratos foram reduzidos em $15 \%$ da média dos pesos com dieta e água à vontade. No experimento 1 , ratos controles e desnutridos foram aleatoriamente designados para os estímulos discriminativos $\left(\mathrm{S}^{\mathrm{DS}}\right)$ luz ou som. As pressões à barra foram reforçadas com água durante a apresentação dos estímulos luz ou som e não reforçadas na ausência destes estímulos $\left(\mathrm{S}^{\Delta}\right)$. Após a média do índice de discriminação (ID) das 6 últimas sessões da discriminação de cada sujeito atingir $80 \%$ foi iniciada a reversão da discriminação. Na reversão, as respostas passaram a ser reforçadas na ausência de luz ou som. Houve efeito do ID no fator sessão, tanto na discriminação quanto na reversão para controles e desnutridos. Não houve efeito de dieta ou de estímulo. Nas primeiras sessões da reversão, todos os grupos mostraram diferenças nas taxas de respostas, tanto em $\mathrm{S}^{\mathrm{D}}$ como em $\mathrm{S}^{\Delta}$ quando comparadas com as 6 últimas sessões da discriminação. No experimento 2, alguns filhotes foram estimulados do nascimento até 35 dias de idade. Foi utilizado o mesmo critério de redução de peso do experimento 1 . No experimento 2, foram utilizadas 2 caixas com uma barra na parede frontal e com 3 túneis para a apresentação dos estímulos: sons (constantes ou interrompidos) e figuras (triângulos e linhas). Foi realizada a modelagem da resposta de colocação do focinho nos túneis (nose poken) e da pressão à barra. As tentativas durante o treino da discriminação foram iniciadas pelas respostas de pressão à barra que produziram a apresentação dos estímulos linha e triângulo em qualquer um dos 3 túneis, sendo que um dos túneis ficava sem estímulo. As respostas de nose poken no túnel com o $\mathrm{S}^{\mathrm{D}}$ linha foram reforçadas com água e as respostas no túnel com o triângulo ou sem estímulo $\left(\mathrm{S}^{\Delta}\right)$ não foram reforçadas. O treino foi prolongado até que o desempenho atingisse $80 \%$ de acertos quando foi iniciada a reversão da discriminação. Na reversão, as respostas de nose poken foram reforçadas no túnel com o triângulo e não foram reforçadas nos túneis com linha e sem estímulo. Após a obtenção do mesmo critério de acertos da discriminação foi iniciado o treino da discriminação condicional. Na condicional, após a resposta de pressão à barra, os estímulos Som Constante ou Interrompido foram apresentados no túnel central e os estímulos linha e triângulo foram apresentados acima de qualquer um dos túneis, sendo que um dos túneis ficava sem estímulo. Durante a apresentação do estímulo condicional Som Constante, as respostas de nose poken foram reforçadas no túnel com a linha e as demais respostas não foram reforçadas. Durante a apresentação do estímulo condicional Som Interrompido as respostas de nose poken foram reforçadas no túnel com o triângulo e as demais respostas não foram reforçadas. Houve efeito de dieta na discriminação, sendo necessárias mais sessões para os desnutridos atingirem o critério em comparação com os controles. Na reversão da discriminação, os desnutridos não estimulados apresentaram um pior desempenho em comparação com os demais grupos. Não houve aquisição na discriminação condicional, mostrando que são necessários outros procedimentos para avaliar processos mais complexos de aprendizagem.

Palavras-chave: 1. Ratos 2. Desnutrição protéica 3. Estimulação 4. Discriminação Simples

5. Discriminação complexa. 


\section{ABSTRACT}

FELICIANO, E. A. DE OLIVEIRA. Simple and complex discrimations: protein malnutrion and stimulation effects. Thesis (Doctorate) - Faculdade de Filosofia, Ciências e Letras de Ribeirão Preto, Universidade de São Paulo, Ribeirão Preto, 2006.

Nutritional deficiency in early life results in morphologic, biochemical and behavioral alterations. The behavioral consequences of malnutrition can be partially recovered by environmental conditions. The objective of Experiment 1 was the analysis the effects of malnutrition in simple discrimination procedures. Experiment 2 was addressed to study the effects of malnutrition and environmental stimulation (handling and environment) effects on simple and complex discriminations. In both experiments, $16 \%$ (Controls - C) or 6\% (Malnourished - D) protein diets were offered to rats from birth to age day 35. From that age up to the end of the experiments, commercial diets were available to the rats. Before age day 85 , the ad libitum weights of the rats were reduced to $85 \%$ of the medium weight with water deprivation. In Experiment 1, control and malnourished rats were randomly assigned to the sound and light discriminative stimuli $\left(\mathrm{S}^{\mathrm{DS}}\right)$. Bar presses were reinforced with water during the light or sound stimulus presentation and not reinforced in the absence of these stimuli (S $\Delta$ ). After each animal obtained the discrimination index of $80 \%$ in 6 consecutive sessions, the reversion of the discrimination initiated. In the reversion, bar presses were reinforced in the period of light or sound off. There was an effect sessions in the discrimination index (DI) in the discrimination as well as in the reversion phase for controls and malnourished. There was no diet effect or type of stimulus effect. In the first session of reversion phase, all groups showed differences in the rate of bar presses, in the SD as well in the $\mathrm{S}^{\Delta}$ when compared with the 6 last sessions of the discrimination phase. In the Experiment 2, half of the pups were stimulated from birth up to 35 days of age. The sessions were initiated after the animals reached the same weight reduction (85\%) as in the Experiment 1 . In Experiment 2, two boxes with a bar in the frontal wall and 3 tunnels in the opposite wall were used. The stimulus sounds (constant or interrupted) and figures of triangles and lines were presented above the tunnels. Bar presses and nose pokes in the tunnels were shaped in each animal. In each trial, bar presses were followed by the presentations of the line and triangle stimuli in two tunnels, and in the third tunnel no stimulus was presented. Nose pokes in the tunnel with the $S^{\mathrm{D}}$ line were reinforced with water and the responses in the tunnel with the triangle or without stimulus $\left(\mathrm{S}^{\Delta}\right)$ were not reinforced. After each animal reached the criterion of $80 \%$ of correct responses, the reversion of the discrimination was initiated. During the reversion phase, nose poke responses were reinforced in the tunnel with the triangle and not reinforced in the tunnels with line or without stimulus. After the same hit criterion of the discrimination phase was reached by each animal, the training of the conditional discrimination initiated. In the conditional phase, after the bar presses a continuous or discontinuous sound stimuli were presented in the central tunnel, and the line or triangle stimuli were introduced above any of the tunnels, and one of the tunnels remained with no stimulus. During the presentation of the conditional stimulus continuous sound, nose pokes in the tunnel with the line were reinforced and responses in the other tunnels were not reinforced. During the presentation of the conditional stimulus discontinuous sound, nose pokes in the tunnel with the triangle were reinforced and the others responses in the tunnels were not reinforced. There was a diet effect in the discrimination phase and more sessions were required for the malnourished animals to reach the criterion, compared to the controls. In the reversion phase, the malnourished not stimulated early in life showed lesser performance in comparison with the others groups. None of the groups showed improvement of the performance in the conditional discrimination phase. The results shows that other procedures will be necessary to improve the acquisition of more complex discriminations

Keywords: 1. Rats 2. Protein malnutrition. 3. Stimulation 4.Simple discrimination. 5. Complex discrimination. 
INTRODUÇÃO 


\subsection{INTRODUÇÃO}

A desnutrição é um dos problemas nutricionais mais preocupantes nos países em desenvolvimento. Segundo dados da Food and Agriculture Organization (FAO), há 820 milhões de pessoas desnutridas no mundo (FAO, 2006).

A desnutrição infantil é um problema de dimensões alarmantes em algumas partes do mundo. Associada à pobreza e à desigualdade, é um expressivo fator de mortalidade de crianças nos países em desenvolvimento, apesar dos esforços realizados nas últimas décadas para reduzir os índices de mortalidade infantil. Um estudo mais recente, realizado pelo Ministério da Saúde e pelo Instituto de Pesquisa Econômica Aplicada (Ipea), mostra que a desnutrição infantil se mantém em queda no Brasil nos primeiros anos desta década. O estudo utilizou dados do Sistema de Informação da Atenção Básica (Siab). As informações referemse à população atendida pelo Programa Agentes Comunitários de Saúde (Pacs) e pelo Programa Saúde da Família (PSF). Dentro desse universo, que corresponde a cerca de $40 \%$ da população brasileira, foram consideradas as crianças menores de dois anos, que representam o grupo mais vulnerável à desnutrição. Entre 1999 e 2004, a porcentagem de crianças com baixo peso para a idade caiu de $10,1 \%$ para $3,6 \%$, no primeiro ano de vida, e de $19,8 \%$ para 7,7\%, no segundo ano, segundo dados do Fundo das Nações Unidas para Infância (UNICEF, 2006). Por outro lado, esses índices são muito menores em comparação aos dos países africanos como Congo, Quênia e Sudão que mostram taxas de mortalidade infantil de 81, 79 e 63, respectivamente (UNICEF, 2006).

A etiologia da desnutrição é multifatorial, pois ela está relacionada à situação de pobreza, condições sanitárias precárias e a baixo padrão sócio-econômico e educacional, o que agrava a situação, desde que doenças, infecções ou distúrbios dos processos metabólicos 
podem levar a alteração na absorção de proteínas, provocando um atraso no crescimento corporal e cerebral (MORGANE et al., 1993).

Uma nutrição adequada durante o período de rápido desenvolvimento é essencial para a formação do Sistema Nervoso Central (SNC) e para o desenvolvimento do organismo. O período de rápido desenvolvimento do SNC, é a fase durante a qual ocorre a formação e maturação do tecido nervoso, isto é, o aumento do tamanho de células, migração de neurônios e células da glia, proliferação e ramificação de dendritos e axônios, mielinização e sinaptogênese (MORGANE; MOKLER; GALLER, 2002). No rato, o período crítico de desenvolvimento do SNC inicia-se na última semana da gestação quando ocorre macro neurogênese e início da microneurogênese, alcançando o pico de crescimento no período pósnatal. Em humanos, este período se inicia no último trimestre de gestação até o segundo ano de vida pós-natal (MORGANE et al., 1993; MORGANE, MOKLER; GALLER, 2002).

A proteína é o nutriente mais importante para a formação e maturação das estruturas do organismo, especialmente na fase de crescimento acelerado do cérebro. É a partir dos aminoácidos que são formadas as proteínas estruturais, enzimas, neuropeptídeos e neurotransmissores. A deficiência de proteína na fase de desenvolvimento do cérebro resulta em prejuízos morfológicos e neuroquímicos no SNC (MORGANE et al., 1993; MORGANE, MOKLER; GALLER, 2002).

Há uma diversidade de modelos em laboratório para introduzir a desnutrição em ratos durante as fases de gestação, lactação ou pós-lactação (CRNIC, 1980) e que interferem na ingestão, na produção do leite materno e nas interações entre ratas-mãe e filhotes.

Para avaliar os efeitos da deficiência nutricional é necessário considerar vários fatores associados que podem reduzir ou intensificar os efeitos da desnutrição, como o tipo, o grau, o período e a duração do insulto. 
Foram descritos vários efeitos marcantes da desnutrição no início da vida sobre aspectos estruturais (DOBBING, 1987; MORGANE et al., 1978), neuroquimicos (PEREIRA DA SILVA; DE OLIVEIRA, 2005; WIGGINS; FULLER; ENNA, 1984) e comportamentais (LEVITSKY; STRUPP, 1995; SMART, 1977).

Grande parte dos estudos com ratos analisou os efeitos da desnutrição sobre o comportamento após um período de recuperação nutricional, realizando medidas dos efeitos em longo prazo da desnutrição no rato adulto. Nos ratos desnutridos foram mostrados aumentos da locomoção no Campo Aberto (BRIONI; ORSINGHER, 1988; SALAS; CINTRA, 1979); redução da atividade exploratória (FRAÑKOVÁ, 1968; FRAÑKOVÁ; BARNES, 1968); redução da exploração das áreas laterais em comparação com as áreas centrais da Tábua de Buracos (De CAMPOS, 2006); maior exploração dos braços abertos no Labirinto em Cruz Elevado (ALMEIDA; GARCIA; DE OLIVEIRA, 1993; PEREIRA DA SILVA; DE OLIVEIRA, 2005; RIUL et al., 1998).

Também tem sido mostrada uma maior sensibilidade dos ratos desnutridos aos estímulos aversivos e redução do limiar de respostas ao choque (ROCINHOLI; ALMEIDA; DE OLIVEIRA, 1997; SMART; WHATSON; DOBBING,1975); latências menores de fuga e esquiva e maior resistência à extinção (ALMEIDA; DE OLIVEIRA, 1994; DE OLIVEIRA; ALMEIDA, 1985).

Em contrapartida, alguns estudos mostraram alterações nas interações entre mães e filhotes desnutridos quando são realizadas medidas concomitantes com o período de desnutrição (DAL BELLO; DE OLIVEIRA, 2004; DE OLIVEIRA, 1985; RIUL et al., 1999). Os filhotes desnutridos permanecem mais tempo no ninho e em amamentação e menos tempo em ninhadas separadas, o que resulta em menor exploração das áreas fora do ninho.

Observações na mesma direção foram descritas em crianças desnutridas no México, mostrando que elas permanecem mais tempo próximas da mãe e menos tempo explorando ou 
brincando fora da casa ou distante da mãe (CHAVES; MARTINEZ; YASCHINE, 1975). Estes dados com animais e crianças fortalecem a hipótese do Isolamento funcional proposta por Levitsky e Barnes (1972). Segundo esta hipótese, durante a desnutrição há uma predominância de comportamentos relacionados com alimentação em detrimento de comportamentos relacionados com atividades de exploração do meio ambiente.

Grande parte dos estudos acima descritos, envolve medidas de comportamento exploratório, locomoção ou desempenho em relação a estímulos aversivos, sendo poucos os estudos que avaliaram aprendizagem, descrita por Catânia (1999) como “uma mudança relativamente permanente no comportamento, resultante da experiência” (Kimble, 1961, p.113).

Alguns estudos mostraram pior desempenho dos ratos desnutridos em tarefas de discriminação visual (CASTRO; RUDY, 1989; CÉLEDON; SMART; DOBBING, 1982; TONKISS; STEPHENS, 1981; TONKISS et al., 1991), em procedimentos de relação espacial, no Labirinto em Y (BARNES et al., 1966) e em procedimentos de discriminção visual com macacos (ZIMMERMANN, 1975).

O estudo de Céledon, Smart e Dobbing (1982) com ratos desnutridos na gestação e lactação mostrou piores desempenhos dos desnutridos em relação aos controles na discriminação de estímulos (barras brancas e barras pretas ou barras verticais e barras horizontais), sendo necessário mais treino para os desnutridos atingir o critério.

O estudo de Tonkiss et al (1991) com ratos adultos recuperados da desnutrição prénatal introduzida cinco semanas antes do acasalamento e durante o período da gestação, com tarefas de discriminação de estímulos de cor (preto e branco), posição (horizontal e vertical) ou forma (círculo e quadrado) mostrou que também foi necessário mais treino para os desnutridos do que para os controles nas tarefas de discriminações. 
Há poucos estudos na literatura que analisaram a reversão da discriminação em desnutridos. No estudo de Barnes et al (1966) os animais desnutridos apresentaram piores desempenhos em comparação com os controles em tarefas de reversão da discriminação no labirinto aquático. Outros estudos (CRAVENS, 1974; SMART, 1977) não mostraram diferenças de desempenho, enquanto Smart (1976) mostrou um melhor desempenho dos animais desnutridos durante as primeiras sessões de treino no labirinto aquático.

No estudo de Smart (1976), a desnutrição protéico-calórica foi introduzida durante a gestação e lactação. Durante as primeiras sessões de treino no Labirinto Aquático em T, os ratos desnutridos aprenderam a discriminação espacial melhor que os controles, entretanto, as diferenças entre desnutridos e controles desapareceram após algumas sessões de treino.

No estudo de Barnes et al., (1966) com um Labirinto Aquático em Y, o desempenho foi pior em ratos criados em grandes ninhadas e que após a lactação foram alimentados com dieta deficiente em proteína, em comparação com o desempenho de ratos amamentados em pequenas ou médias ninhadas durante a lactação e que na pós-lactação receberam dieta com boa quantidade de proteína. Mesmo após três meses de recuperação nutricional, os ratos controles apresentaram melhor desempenho do que os desnutridos.

Na revisão de Smart (1977), sobre procedimentos de discriminação visual, espacial e reversão da discriminação, dos nove estudos de discriminação visual citados na revisão, em três deles o desempenho dos controles foi melhor do que o dos desnutridos e em seis estudos não houve diferenças. Dos quatro experimentos de discriminação espacial, apenas um mostrou melhor desempenho dos controles em relação aos desnutridos e em três deles não houve diferença. Na reversão da discriminação, apenas um estudo mostrou melhor desempenho dos controles em relação aos desnutridos.

Nos procedimentos de reversão da discriminação de posição esquerda e direita (NORTH, 1950), branco e preto (MACKINTOSH et al, 1968) e de diferentes odores 
(O’GRADY; JENNING, 1974) ou ainda, na comparação do desempenho de diferentes modalidades de estímulos (FELICIANO; SOUZA; DE OLIVEIRA, 2002, NIGROSH; SLOTNICK; NEVIN, 1975), todos os autores sugerem a necessidade de refinamento dos procedimentos para melhor identificar as variações do responder.

Um refinamento de procedimento para avaliar processos de aprendizagem de discriminação em ratos foi desenvolvido por Tonkiss e Sthephens (1981) com sobreposição de estímulos. Não houve diferenças entre desnutridos e controles diante de um estimulo luminoso que sinalizava punição, nem mesmo quando um tom foi sobreposto ao estimulo luminoso. Os controles mostraram índices maiores de supressão de respostas à barra diante do tom do que os desnutridos quando o tom foi apresentado sozinho.

Os procedimentos de aprendizagem observacional, redundante e latente mostraram um pior desempenho dos animais desnutridos em comparação aos controles (LEVITSKY, 1979). Sendo assim, na maioria dos procedimentos as diferenças entre controles e desnutridos somente são observadas quando são analisados aspectos mais sutis do comportamento, como nos procedimentos descritos por Levitsky (1979) e no estudo de Tonkiss e Sthephens (1981).

As conseqüências da desnutrição sobre o comportamento não são devidas apenas à falta de nutrientes, podendo ser agravadas pelas condições precárias de estimulação em que vivem as populações desnutridas. Crianças desnutridas normalmente vivem em ambientes com escassos recursos físicos, econômicos e sociais onde há pouca estimulação e participação dos pais nas interações com a criança e nas atividades de brincadeira das mesmas (GRANTHAM-MCGREGOR, 1995).

Sabe-se que o desenvolvimento de um animal está relacionado por uma complexa relação entre fatores biológicos e ambientais (VARTY et al, 2000). A introdução da estimulação precoce promove o crescimento, acelera o desenvolvimento fisiológico e comportamental (FIELD, 1998; FIELD et al., 1986). A estimulação em animais pode ser 
realizada através do: - ambiente enriquecido: envolve a criação de animais em ambientes ricos em estímulos físicos (rodas, brinquedos, espelho, etc.) que permitem a manipulação do animal, durante o período de lactação e/ou pós-lactação (ROSENZWEIG; BENNET, 1977; VARTY et al., 2000),

- enriquecimento ambiental social: alojamento dos animais em grupos para maior interação social (DE OLIVEIRA; ALMEIDA, 1985).

- estimulação táctil (handling): os animais são “acariciados” pelo experimentador, durante o período de lactação ou pós-lactação, todos os dias ou apenas alguns dias da semana (PEREIRA DA SILVA; DE OLIVEIRA, 2005; RIUL et al., 1998, ROCINHOLI; ALMEIDA; DE OLIVEIRA, 1997).

Ou ainda, como sugere Swanson et al, (1983) através da combinação destes.

Frañková (1968), sugeriu que o prejuízo no desenvolvimento resultante da desnutrição no início da vida poderia ser em parte recuperado, através do handling.

Tem sido relatado que a estimulação ambiental resulta em aumento nos níveis de noradrenalina cortical e redução da serotonina (RENNER; ROSENZWEIG, 1987), maior liberação do hormônio de crescimento em animais que foram privados de cuidados maternos (SCHANBERG; FIELD, 1987), redução do ácido desoxirribonucléico (DNA) (CRNIC, 1983). Registros eletro fisiológicos mostraram uma redução da latência e do intervalo entre picos do Potencial Evocado Auditivo (PEA) (ROCINHOLI; DE OLIVEIRA; COLAFÊMINA, 2001 a, 2001 b).

Shamberg e Field (1987) mostraram que a estimulação (handling) resultou em aumento da ornitina descarboxilase (ODC), levando ao aumento na síntese de proteína e hormônios do crescimento. Rosenzweig, Love e Bennet (1968), mostraram aumento no peso 
cerebral, na espessura de mielina e melhora na eficiência de sinapse resultante de um aumento da espessura das membranas pré e pós sinápticas em animais estimulados.

Os efeitos da estimulação neonatal persistem durante a maturidade. Animais que foram estimulados durante o período neonatal, quando comparados aos não estimulados, perdem menos neurônios piramidais e receptores de glicocorticóide no hipocampo e mostram um desempenho melhor em testes de aprendizagem espacial (MEANEY et al., 1988).

A estimulação neonatal também afeta o aprendizado dependente do hipocampo, o volume hipocampal e a lateralização cerebral (VERSTYNEIN et al., 2001). Além disso, ela afeta outros tipos de plasticidade hipocampal como, por exemplo, a potenciação de longa duração (LTP), com um aumento de longa duração na eficácia sináptica causada por breve estimulação tetânica. A LTP no hipocampo desenvolve-se no período pós-natal, alcançando os níveis adultos após a terceira semana pós-natal (WILSON et al., 1986). Ratos expostos à estimulação neonatal quando adultos apresentam um aumento na amplitude da LTP no hipocampo (WILSON et al., 1986).

Quanto aos efeitos da estimulação ambiental sobre o comportamento em ratos, os filhotes desnutridos estimulados, quando comparados com os não estimulados, apresentam menor nível de emocionalidade e maior exploração de objetos novos (DENENBERG, 1969), melhor desempenho no Labirinto Hebb-Williams (CELEDÓN; SANTANDER; COLOMBO, 1979; MURTHA; PAPAS; RAMAN, 1990), aumento do limiar de respostas a estímulos aversivos dolorosos (ROCINHOLI; ALMEIDA, DE OLIVEIRA, 1997).

Em testes específicos de ansiedade, ratos estimulados apresentam maior freqüência de exploração dos braços abertos no Labirinto em Cruz Elevado (FERNÁNDEZ-TERUEL et al., 1990, PEREIRA DA SILVA; DE OLIVEIRA, 2005). 
Animais bem nutridos criados em ambiente enriquecido mostraram latências menores para encontrar a plataforma de fuga no Labirinto Aquático de Morris (PUURUNEN et al., 2001).

Ratos desnutridos quando mantidos em grupos apresentam comportamentos mais semelhantes aos dos controles em procedimentos de esquiva (DE OLIVEIRA; ALMEIDA, 1985).

Sendo assim, enquanto a desnutrição resulta em prejuízos estruturais e neuroquímicos no SNC a estimulação, por sua vez, produz outras alterações na estrutura e bioquímica ao longo do desenvolvimento do organismo, resultando em mudanças que podem reverter, pelo menos em parte, os prejuízos causados pela desnutrição no cérebro e no comportamento.

De modo geral, os estudos em laboratório podem envolver relações de contingências e interações mais complexas. O modelo de discriminação condicional tem se revelado útil no estudo de uma série de processos comportamentais descritos como aprendizagem complexa. Primeiramente abordado nos estudos de Lashey (1938), conforme comentam Cumming e Berryman (1965) como uma das primeiras tentativas de estudar relações condicionais em ratos.

O estabelecimento de relações de controle condicional diretamente ensinada, bem como a transferência do controle destas relações para situações novas, vem recebendo atenção especial nos estudos sobre comportamento complexo nas últimas décadas, principalmente com o crescimento da área de equivalência de estímulos.

Diferentemente de uma situação de discriminação simples definida como “aprendizagens que derivam de processos de controle de estímulos mais simples” (SKINNER, 1953. p. 115), em que se estabelece uma relação constante entre um estímulo antecedente e uma resposta, nas discriminações condicionais essa relação muda de acordo com o contexto, 
isto é, "o papel de um estímulo depende de outros que forneçam o contexto para ele" (CATANIA, 1999, p 163). Em uma discriminação condicional deve-se reforçar uma resposta a um determinado estímulo específico apenas na presença de um outro estímulo.

Em uma das primeiras revisões da literatura sobre discriminação condicional, (CUMMING; BERRYMAN, 1965, p. 285), os autores descrevem esses tipos mais complexos de discriminação como se um estímulo (o condicional) funcionasse como um "seletor de discriminações”, mais do que seletor de respostas individuais. Respostas a um estímulo discriminativo especifico $\left(S^{\mathrm{D}} 1\right)$ e não outro $\left(S^{\mathrm{D}} 2\right)$ seriam seguidas de reforço apenas se estiver presente um estímulo condicional específico (SC1). Além disso, para Cumming e Berryman (1965), o estímulo condicional teria uma função seletiva que momentaneamente fortalece uma discriminação específica.

A maioria dos estudos sobre discriminações condicionais tem sido realizado através do procedimento de matching to sample (pareamento ao modelo ou igualação ao modelo) (SIDMAN, 1994) que permite o estudo de diferentes pareamentos de estímulos para a análise de processos de discriminações complexas em animais (CUMMING; BERRYMAN, 1965; NAKAGAWA, 2001) e em crianças (DE ROSE et al., 1989; DEVANY; HAYES; NELSON, 1986).

Esse procedimento pode apresentar duas formas em relação à possibilidade de permanência ou retirada do estimulo modelo, no momento de apresentação dos estímulos de comparação, ou seja, no pareamento simultâneo (o estimulo modelo e os estímulos de comparação ou de escolha ficam simultaneamente exibidos) e no pareamento sucessivo (os estímulos de comparação só são apresentados após a retirada do estimulo modelo).

No procedimento de maching-to sample, os estímulos modelo controlam a função discriminativa positiva $\left(\mathrm{S}^{+}\right)$ou negativa ( $\left.\mathrm{S}^{-}\right)$dos estímulos de comparação. A apresentação de um dos estímulos modelo indica qual dos estímulos de comparação funciona como $\mathrm{S}^{+}$e qual 
funciona como $\mathrm{S}^{-}$Em geral, requer que o sujeito responda ao estimulo modelo (resposta de observação) e a resposta produz os estímulos de comparação. Respostas ao estimulo de comparação com função de S+ na presença do estimulo modelo especifico são seguidas de reforçamento. Respostas aos estímulos de comparação com função de S-, na presença de determinado estímulo modelo, não são seguidas de reforçamento. Sendo assim, a apresentação do estímulo modelo indica qual dos estímulos de comparação terá a função de estímulo positivo, diante do qual a resposta será reforçada ou estímulo negativo, diante do qual a resposta não será reforçada.

As relações entre os estímulos também podem implicar no emparelhamento arbitrário, onde os estímulos modelos e de comparação não se assemelham fisicamente (CARTER; ECKERMAN, 1975, TOMONAGA, 1993). Nesse caso, diante do estímulo modelo A1, respostas ao estímulo de escolha B1 serão seguidas de reforço. Diante do modelo B2 apenas na presença de A2. Tais desempenhos demonstram aprendizagem de relações condicionais entre estímulos arbitrários que não compartilham das mesmas características físicas. Outra variação do emparelhamento com o modelo é o emparelhamento por singularidade (oddityfrom-sample) que consiste em apresentar um estímulo de comparação idêntico ao modelo e outro estímulo de comparação diferente do modelo e as respostas são sempre reforçadas no estímulo de comparação diferente do modelo (CATANIA, 1999).

Tem sido amplamente demonstrado que após treino de discriminações condicionais utilizando o procedimento de comparação com o modelo, se testes apropriados forem conduzidos, sujeitos humanos freqüentemente demonstram relações condicionais não diretamente treinadas, também chamadas de relações emergentes (DEVANY; HAYES; NELSON, 1986; SIDMAN; TAILBY, 1982). Relações entre estímulos não treinadas desenvolvidas pelos sujeitos a partir de relações condicionais treinadas tem sido largamente estudadas pelos analistas do comportamento. As relações derivadas de reflexividade (em que 
um elemento mantém uma relação verdadeira consigo mesmo, exemplo: $A=A$ ), ou relação de simetria (relações em que a ordem dos termos é reversível, exemplo: se A=B então B=A) ou ainda, relação de transitividade (relações em que os termos comuns em 2 pares ordenados determinam um terceiro par ordenado, exemplo: se $\mathrm{A}=\mathrm{B}$ e $\mathrm{B}=\mathrm{C}$, então $\mathrm{A}=\mathrm{C}$ ) (CATANIA, 1999, p.166) foram consideradas por Sidman e Tailby (1982) como propriedades definidoras de um fenômeno chamado de equivalência de estímulos, estendendo à análise do comportamento uma das definições matemáticas de equivalência.

Os estudos publicados nos últimos 30 anos mostraram que a equivalência de estímulos tem sido documentada com relativa facilidade com sujeitos humanos (DEVANY; HAYES; NELSON, 1986; SIDMAN; TAILBY, 1982) e com indicativos de propriedades da equivalência com sujeitos não humanos, como periquito (MANABE; KAWASHIMA; STADDON, 1995), leão-marinho (KASTACK; SHUSTERMAN; KASTACK, 2001; SCHUSTERMAN; KASTACK, 1993), elefanta (NISSANI et al., 2005), pombo (VAUGHAN, W, 1988; ZENTALL; URCUIOLI, 1993), macaco (BARROS; GALVÃO; MCILVANE, 2002; MCINTIRE; CLEARY; THOMPSON, 1987; TOMONAGA et al, 1991) e em abelha (MORENO et al, 2005).

Foram encontradas dificuldades para o estabelecimento da discriminação condicional em ratos (IVERSEN, 1993, 1997). Iversen (1993) utilizou estímulos visuais (luz contínua e piscante) que foram dispostos em 3 chaves em uma parede da caixa experimental. O estímulo modelo foi apresentado na chave central e os estímulos de comparação nas laterais. Se o modelo fosse luz contínua as respostas eram reforçadas no estímulo de comparação luz contínua e se o modelo fosse luz piscante, as respostas eram reforçadas no estímulo de comparação luz piscante. Após algumas sessões, as seqüências de tentativas programadas foram aleatórias e os resultados mostraram que os ratos atingiram altas porcentagens de acertos. 
Posteriormente, Iversen (1997) com o objetivo de verificar se existia um controle da resposta pela posição do estímulo modelo, variou a posição do estímulo modelo a cada sessão. Os resultados mostraram um aumento do número de erros quando o estímulo modelo não era apresentado no centro, concluindo que o controle do responder estava relacionado com a posição do estímulo modelo e não apenas com a similaridade física dos estímulos.

Galvão et al (2002) vêm conduzindo um programa de pesquisas nomeado "Escola Experimental de Primatas” cujo objetivo é o estudo de repertório discriminativo complexo e emergente, como a identidade generalizada e a formação de classes de equivalência. Os dados disponíveis na literatura indicam que o papel da linguagem na formação de classes de estímulos equivalentes ainda permanece obscuro. Resultados positivos e fidedignos com sujeitos não humanos poderiam por fim a esse impasse, indicando que a linguagem não é necessária para a formação de classes de equivalência.

Levando em conta as dificuldades de estabelecer discriminações condicionais em ratos, foram desenvolvidos neste estudo equipamentos para estudar discriminações simples e condicionais em ratos controles e desnutridos (estimulados ou não), como uma tentativa de novos procedimentos para avaliar processos mais complexos de aprendizagem. 


\subsection{OBJETIVOS}

- Avaliar os efeitos da desnutrição protéica e da estimulação táctil e auditiva sobre o desenvolvimento dos filhotes durante a lactação e a pós-lactação.

- Comparar o desempenho de ratos controles e desnutridos em procedimentos de discriminação simples de luz ou som e reversão da discriminação.

- Comparar o desempenho de ratos controles e desnutridos (estimulados ou não) na aquisição de discriminações simples e complexas.

- Desenvolver procedimentos que permitam o estudo de processos de aprendizagem complexa 


\subsection{METODO}

\section{Experimento 1}

\subsection{Sujeitos}

Foram utilizados 32 ratos machos, da espécie Rattus norvegicus, linhagem Wistar, com 85 dias de idade, nascidos dos cruzamentos de animais realizados no biotério do Laboratório de Nutrição, Desenvolvimento e Comportamento da Faculdade de Filosofia, Ciências e Letras de Ribeirão Preto - USP.

\subsection{Procedimentos gerais}

Os animais (machos adultos e fêmeas virgens) provenientes do biotério central passaram por um período de adaptação no laboratório até atingirem o peso corporal de aproximadamente 300gramas para a realização dos cruzamentos. Durante o período de adaptação, os ratos machos foram alojados individualmente enquanto que as ratas fêmeas em grupos de 3 por caixa.

Para os cruzamentos, as ratas foram colocadas nas caixas dos machos na proporção de 3 fêmeas para cada macho, durante 5 dias consecutivos. Após esse período, os ratos machos foram retirados das caixas e eliminados.

Em torno do $15^{\circ}$ dia do período da gestação (uma semana antes da data prevista para o parto), as ratas foram alojadas individualmente e permaneceram nessa condição até o nascimento dos filhotes. As ninhadas foram compostas logo após o parto.

\subsection{Composição das ninhadas}

No dia do nascimento, todos os filhotes foram separados de suas mães e agrupados em um conjunto maior. Em seguida, foram separados por sexo e designados aleatoriamente para 
uma das ratas-mãe. As ninhadas foram compostas por 1 rata-mãe, 6 filhotes machos e 2 fêmeas e foram divididas em 2 grupos: Controles (C) e Desnutridas (D).

Do nascimento aos 21 dias de idade (lactação) e dos 22 aos 35 dias de idade (póslactação) foram oferecidas às ninhadas dietas balanceadas (ANEXO A), à vontade, contendo 16\% (C) e 6\% de proteína (D). As dietas foram preparadas de acordo com as recomendações do American Institute of Nutrition (Reeves et al., 1993) e a composição de sais minerais e vitaminas está descrita nos ANEXOS B e C.

Dos 35 dias de idade até o final do experimento os animais foram mantidos com ração comercial à vontade (Nuvital Nutrientes Ltda; Colombo, PR), (ANEXO D) e a água foi oferecida à vontade até 81 dias de idade. Aos 81 dias de idade (final da tarde), foi iniciada a restrição de água para reduzir o peso corporal dos ratos para o início do treino da discriminação.

Dos 77 aos 81 dias de idade, todos os ratos foram pesados diariamente para o cálculo da média do peso de cada rato com água e dieta à vontade (linha de base). Aos 81 dias de idade, foi iniciada a restrição de água até que fosse obtida uma redução do peso corporal em 15\% do peso da linha de base, que ocorria 3 ou 4 dias após a restrição de água. Após o inicio do treino foi oferecida água no final das sessões em quantidade suficiente para a manutenção do peso corporal em 85\% da linha de base (aceitando oscilações de pesos 5\% abaixo ou acima dos $85 \%)$. As sessões foram realizadas diariamente.

A Tabela 1 mostra o procedimento de manutenção dos animais durante os períodos de lactação e pós-lactação. 
Tabela 1. Procedimento de manutenção dos animais indicando a dieta oferecida na lactação e pós-lactação (1-35dias de idade), da dieta da pós-lactação (35 dias até final do experimento) e do oferecimento da água (81 dias até final do experimento) para os animais dos grupos controle (C) e desnutrido (D)

\begin{tabular}{lccc}
\hline GRUPOS & \multicolumn{2}{c}{ LACTAÇÃo / PÓS-LACTAÇÃo } & PÓS-LACTAÇÃo \\
& $1-35$ dias & 35 dias até final & 81 dias até final \\
& do experimento & do experimento \\
& Dieta & Dieta e Água & Água \\
D & 16\% proteína & Comercial à vontade & restrita \\
& $6 \%$ proteína & Comercial à vontade & restrita \\
\hline
\end{tabular}

\subsection{Alojamento dos animais}

Para o alojamento dos animais durante os períodos de adaptação, cruzamento e gestação foram utilizadas caixas de polipropileno (41 x 40 × $17 \mathrm{~cm}$ ), com tampas de aço inoxidável nas quais havia espaço para a colocação da ração e bebedouros. Todas as caixas foram forradas com raspas de madeira.

Para o período da lactação foram utilizadas caixas $(40$ × 30 × $20 \mathrm{~cm})$ com tampas e paredes de acrílico transparente onde foram adaptados túneis $(15$ x 5 x $5 \mathrm{~cm})$ para a colocação dos comedouros $(5 \times 5 \times 5 \mathrm{~cm})$ nos quais foram colocadas as dietas de 16 e $6 \%$ de proteína.

Durante o período de pós-lactação até o final do experimento, os animais foram mantidos individualmente em caixas de polipropileno (30 x 19 × $13 \mathrm{~cm}$ ), com tampas de aço inoxidável e bebedouros acoplados. 


\subsection{Condições ambientais do biotério}

O biotério onde os animais foram criados e mantidos tinha a temperatura em torno de $25{ }^{\circ} \mathrm{C}$ e iluminação artificial programada para ciclos de claro e escuro, com duração de 12 horas cada um, com o início do ciclo claro às 6:00 horas.

\subsection{Limpeza das caixas}

Foi feita a limpeza das caixas 3 vezes por semana, substituindo-se as caixas de polipropileno e as raspas de madeira.

\subsection{Composição das dietas}

O ANEXO A se refere à composição das dietas oferecidas durante o período de lactação (1-21 dias de idade) e pós-lactação (22-35 dias de idade), mostrando que a dieta controle continha $16 \%$ de proteína enquanto que a dieta deficiente continha $6 \%$ desse componente. A porcentagem dos outros constituintes foi a mesma, com exceção da de carboidrato, que foi aumentada na dieta deficiente para a obtenção de dietas isocalóricas. Ambas as condições de dieta foram suplementadas com L-metionina em 2,0 g/Kg de proteína, uma vez que a caseína é deficiente nesse aminoácido.

A composição de sais minerais e de vitaminas está representada nos ANEXO B e C.

As dietas preparadas, as misturas de vitamina e de sais minerais foram armazenadas em geladeira para melhor conservação das propriedades nutricionais.

A composição da dieta comercial de laboratório fornecida aos animais a partir dos 35 dias de idade, encontra-se detalhada no ANEXO D. 


\subsection{Equipamentos}

Foram utilizadas 12 caixas de Skinner (20,4 x 24,3 x 20,5 cm) (modelo Funbec - SP, modificada pela Insight Equipamentos Científicos, Ribeirão Preto-SP, Brasil) contendo 3 paredes de alumínio com portas e teto de acrílico transparente.

Na parede lateral direita da caixa foi instalada uma barra (altura de $7 \mathrm{~cm}$ do piso) e o bebedouro estava localizado logo abaixo da barra. O acionamento do pescador permitiu a apresentação do reforço (água). A água foi colocada em um reservatório externo $\left(165 \mathrm{~cm}^{3}\right)$. Um sistema de comando do bebedouro permitiu a apresentação manual do reforço durante 5 segundos na modelagem da resposta de pressão à barra.

As caixas de Skinner foram instaladas dentro de câmaras de madeira (55 x 54 x 54 cm) para o isolamento de ruídos externos. Dentro das câmaras foi instalada uma luz ambiente (127 V.A.C) e um ventilador. Na parede externa da câmara havia uma janela de vidro $(15 \mathrm{x} 21 \mathrm{~cm})$ na qual foi adaptada uma chapa de aço que cobria a janela para melhor controle da iluminação interna das caixas.

As barras, os bebedouros e as luzes das caixas foram comandados por uma interface de 64 canais de entrada e 64 canais de saída (Insight Equipamentos Científicos, Ribeirão Preto, Brasil), acoplada a um computador (IBMPC Pentium 2.2).

A programação de todos os parâmetros do procedimento foi comandada por um programa em Visual Basic ${ }^{1}$ que permitiu o controle da apresentação dos estímulos e o registro do desempenho durante todo experimento.

\footnotetext{
${ }^{1}$ A programação do experimento foi realizada pelo técnico Eldereis de Paula, Departamento de Física e Matemática - USP - RP e Bolsista de Aperfeiçoamento - CNPq.
} 


\subsection{Procedimento do treino da discriminação}

Aos 85 dias de idade (início do treino), os animais controles e desnutridos foram aleatoriamente designados para 4 grupos: Controle Luz (CL), Desnutrido Luz (DL), Controle Som (CS) e Desnutrido Som (DS), sendo que a metade dos animais controles foi designada para o estímulo discriminativo $\left(\mathrm{S}^{\mathrm{D}}\right)$ Som e a outra metade para o $\mathrm{S}^{\mathrm{D}}$ Luz e da mesma forma para os desnutridos. Para o grupo com $\mathrm{S}^{\mathrm{D}}$ Som o estímulo delta $\left(\mathrm{S}^{\Delta}\right)$ foi Sem Som e para o grupo com $S^{\mathrm{D}}$ Luz o $\mathrm{S}^{\Delta}$ foi Sem Luz.

Após a modelagem da resposta de pressão à barra (100 reforços), as respostas à barra foram reforçadas durante 4 sessões de 150 reforços em esquema de Reforçamento Contínuo (CRF) sem apresentação dos estímulos. Após as sessões de CRF, iniciou-se o treino da discriminação.

Os $S^{D}$ Luz ou Som foram apresentados até que ocorressem 3 reforços em cada $S^{D}$ Após a obtenção dos 3 reforços, foram interrompidos as apresentações dos $S^{\text {DS }}$ (luz ou som) e iniciado o $\mathrm{S}^{\Delta}$ com durações variáveis (30, 90 ou 120 s), selecionadas aleatoriamente pelo programa. Para o grupo com $S^{\mathrm{D}}$ Som as respostas de pressão à barra foram reforçadas com durante a apresentação do $\mathrm{S}^{\mathrm{D}}$ Som $(2.5 \mathrm{kHz})$ e não reforçadas durante o período sem Som $\left(S^{\Delta}\right)$. Para o grupo com $S^{D}$ luz as respostas de pressão à barra foram reforçadas durante a apresentação do S ${ }^{\mathrm{D}} \operatorname{Luz}\left(29,8\right.$ Lux) e não reforçadas durante o período Sem luz (S ${ }^{\Delta}$ ).

Foram registradas as freqüências de respostas em $\mathrm{S}^{\mathrm{D}}$ e $\mathrm{S}^{\Delta}$, as respostas por segundo e os intervalos entre respostas. As sessões de treino consistiam de 20 ciclos alternados de $S^{\mathrm{D}}$ e $S^{\Delta}$. As respostas de pressão à barra durante a apresentação dos $S^{D}$ (Luz ou Som) foram reforçadas em esquema de Razão Variável (RV 12:1). 
O treino da discriminação foi prolongado até que o desempenho dos sujeitos atingisse uma média de índice de discriminação (ID) igual a 80\% de acertos.

Para a análise da estabilidade do desempenho foram consideradas as médias dos ID das sessões $(10,11,12,13,14,15)$, fase em que o desempenho estava estável. O desempenho foi considerado estável quando a média do ID das sessões 10,11 e 12 e das sessões 13,14, e 15 não diferenciasse em mais de $10 \%$. Após a estabilidade do desempenho foi iniciada a reversão da discriminação.

\subsection{Reversão da discriminação}

Nesta fase, as respostas de pressão à barra dos sujeitos designados anteriormente para o $\mathrm{S}^{\mathrm{D}}$ Luz (controles e desnutridos) passaram a ser reforçadas durante o período Sem Luz (novo $S^{D}$ ) e as respostas durante o período de Luz (novo $S^{\Delta}$ ) não foram reforçadas. As respostas de pressão à barra dos sujeitos designados anteriormente para o $\mathrm{S}^{\mathrm{D}}$ Som (controles e desnutridos) passaram a ser reforçadas no período Sem Som (novo $\mathrm{S}^{\mathrm{D}}$ ) e as respostas durante a apresentação do estímulo Som (novo $S^{\Delta}$ ) não foram reforçadas.

Na reversão da discriminação foram realizadas 10 sessões de 20 ciclos alternados de apresentação de $S^{\mathrm{D}}$ e $\mathrm{S}^{\Delta}$.

Na Tabela 2 está descrito o procedimento de discriminação e reversão de modo sumarizado. 
Tabela 2. Resumo do procedimento da discriminação $\left(S^{D}\right.$ Luz ou Som e $S^{\Delta}$ Sem luz ou Sem Som) e reversão ( $S^{D}$ Sem Luz ou Sem Som e $S^{\Delta}$ Luz ou Som) para os grupos Controle Luz (CL), Desnutrido Luz (DL), Controle Som (CS) e Desnutrido Som (DS)

\begin{tabular}{|c|c|c|c|c|c|}
\hline \multicolumn{4}{|c|}{ DISCRIMINAÇÃO } & \multicolumn{2}{|c|}{ REVERSÃO } \\
\hline Estímulo & Procedimento & Duração & Estímulo & Procedimento & Duração \\
\hline$S^{D}-L u z$ & RV 12:1 & 3 reforços & $S^{D}-$ Sem Luz & RV:12:1 & 3 reforços \\
\hline $\mathrm{S}^{\Delta-}$ Sem Luz & Extinção & 30,60 ou $120 \mathrm{~s}$ & $S^{\Delta}-$ Luz & Extinção & 30,60 ou $120 \mathrm{~s}$ \\
\hline$S^{\mathrm{D}}$ Som & RV 12:1 & 3 reforços & $\begin{array}{l}\mathrm{S}^{\mathrm{D}} \text { Sem Som } \\
\text { RV:12:1 }\end{array}$ & $\mathrm{RV}: 12: 1$ & 3 reforços \\
\hline$S^{\Delta}$-Sem Som & Extinção & 30,60 ou $120 \mathrm{~s}$ & $\mathrm{~S}^{\Delta}-\mathrm{Som}$ & Extinção & 30,60 ou $120 \mathrm{~s}$ \\
\hline
\end{tabular}

\subsection{Experimento 2}

\subsection{Sujeitos}

Foram utilizados 24 ratos machos, da espécie Rattus norvegicus, linhagem Wistar, com 85 dias de idade, nascidos dos cruzamentos de animais realizados no biotério do Laboratório de Nutrição, Desenvolvimento e Comportamento da Faculdade de Filosofia, Ciências e Letras de Ribeirão Preto - USP.

\subsection{Procedimentos Gerais}

Para o experimento de discriminação complexa foram mantidos os mesmos procedimentos do experimento descrito anteriormente durante os períodos de adaptação, cruzamento, composição da ninhada, manutenção de dietas com 16 \% (C) e 6\% (D) de 
proteína durante a lactação e pós-lactação, manutenção com dieta comercial e água à vontade (35 aos 81 dias de idade), cálculo da média do peso de cada sujeito com dieta é água à vontade (77 aos 81 dias de idade) para redução do peso em 15\% da linha de base e restrição de água a partir dos 81 dias de idade

Além das manipulações realizadas descritas no experimento 1 (Tabela 1), durante os períodos de lactação e pós-lactação (1-35 dias de idade) foram realizadas a estimulação táctil e auditiva descritas abaixo.

Aos 85 dias de idade, os animais foram designados aleatoriamente para os grupos Controle não Estimulado (CN), Desnutrido Não Estimulado (DN) Controle Estimulado (CE) e Desnutrido Estimulado (DE). Após as sessões de treino foi oferecida água aos sujeitos para a manutenção do peso corporal em 85\% da linha de base (aceitando oscilações de pesos 5\% abaixo ou acima dos $85 \%)$.

\subsection{Procedimento da estimulação táctil e auditiva}

A estimulação dos filhotes das ninhadas (CE e DE) foi realizada diariamente desde o nascimento até 35 dias de idade. No período da lactação, as ratas-mãe de todas as ninhadas foram retiradas e colocadas em caixas individuais, por aproximadamente 27 minutos (tempo que durava a estimulação). Todos os filhotes foram mantidos no ninho recobertos por uma manta de algodão para manutenção da temperatura corporal. Os filhotes estimulados foram retirados individualmente para a realização do procedimento de estimulação táctil (handling).

A estimulação táctil consistia em segurar cada filhote com uma das mãos e deslizar suavemente o polegar da outra mão na parte dorsal do animal no sentido encéfalo-caudal durante três minutos (Lima et al.,1999). 
Após a estimulação táctil, os animais estimulados foram agrupados nas caixas e levados sem as ratas-mãe para uma sala (distante 17 metros do biotério), onde foram apresentados para a ninhada estímulos auditivos de tons puros de $70 \mathrm{~dB}(3 \mathrm{kHz})$, durante $3 \mathrm{~s}$, com intervalos de 25 segundos entre os tons. A estimulação auditiva foi mantida por 3 minutos. Após a estimulação auditiva, as ninhadas retornavam ao biotério, onde as ratas-mãe das ninhadas estimuladas e não estimuladas foram recolocadas nas caixas de lactação com seus respectivos filhotes.

\subsection{Equipamentos}

Foram utilizadas duas caixas de Skinner modificadas (32,6 x 34,5 x $21 \mathrm{~cm})$ como pode ser observado nas Figuras 1 e 2. Cada caixa continha uma barra localizada na parede lateral esquerda. A parede lateral direita (lado oposto à barra) foi dividida em 3 partes formando um ângulo de $45^{\circ}$ entre a parte central e as duas laterais.

Nestas 3 subdivisões foram instalados 3 túneis (3cm de diâmetro e $5 \mathrm{~cm}$ de profundidade) para a apresentação do reforço (água). Sobre os túneis central e lateral foram adaptados os sistemas de apresentação dos estímulos para o treino das diversas fases do procedimento. Logo acima de cada túnel foram instalados os seguintes estímulos:

- Luz (não utilizada neste experimento);

- Linha vertical (Figura 2);

- Triângulo (Figura 2);

- Som (acionado por um auto falante instalado dentro de cada túnel e podia ser apresentado de forma constante ou pulsante). 
O reforço foi apresentado durante $5 \mathrm{~s}$, através do acionamento da concha do pescador (dentro de cada túnel havia um orifício que permitia o encaixe da concha) após a resposta correta.

Dentro de cada túnel, foram instalados sensores para o registro das respostas de nose poken ou colocação do focinho dentro dos túneis. A barra, os sensores, a apresentação dos estímulos e o controle dos procedimentos durante as fases do experimento foram comandados por um computador Pentium 2.2 e uma interface de 64 canais de entrada e 64 canais de saída .

A Figura 1 mostra uma visão geral da caixa experimental utilizada neste estudo e a Figura 2 mostra uma visão detalhada dos túneis central e lateral onde foram apresentados os estímulos.

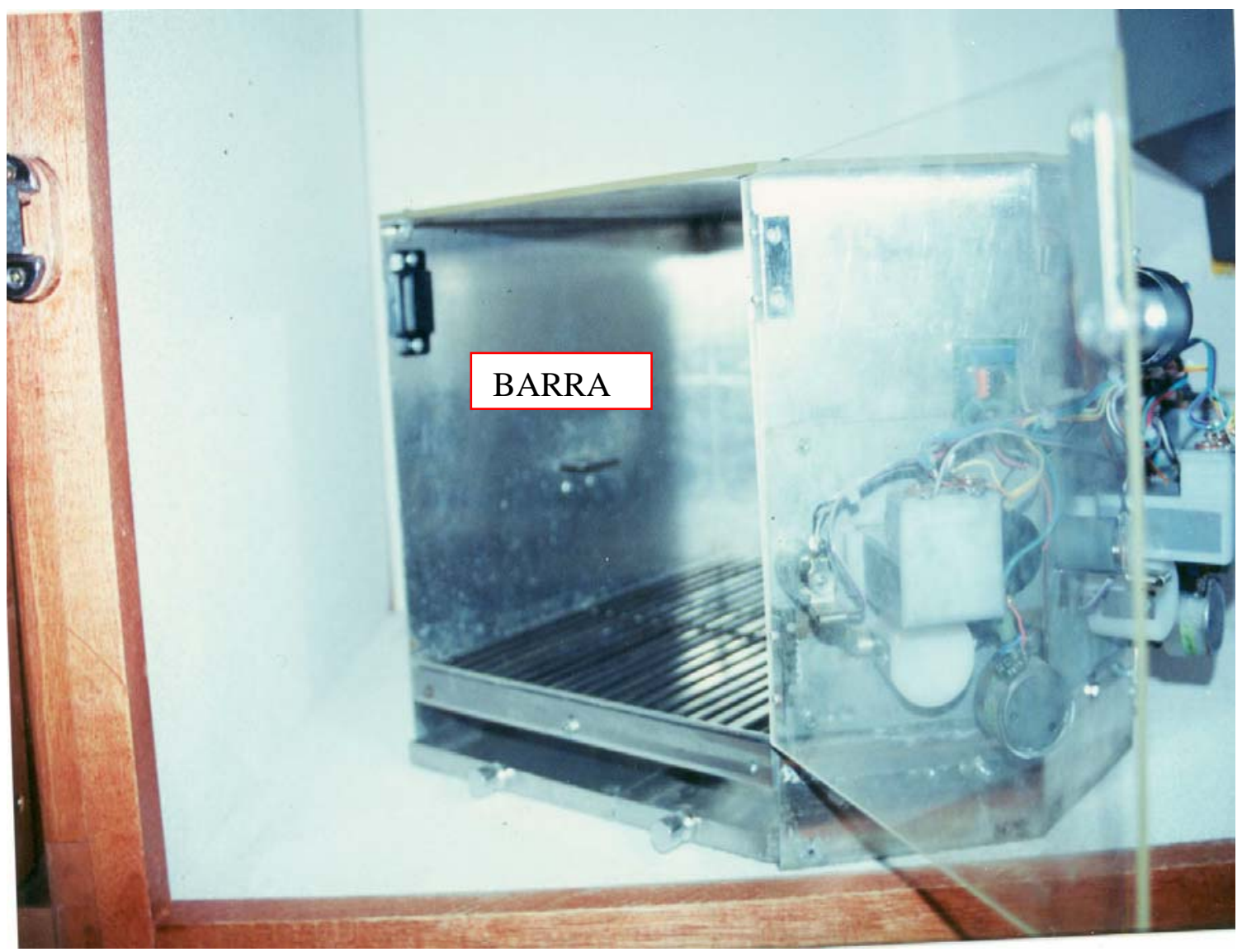

Figura 1. Fotografia da caixa utilizada no experimento de discriminação complexa com detalhes da barra que produzia o início das tentativas. 


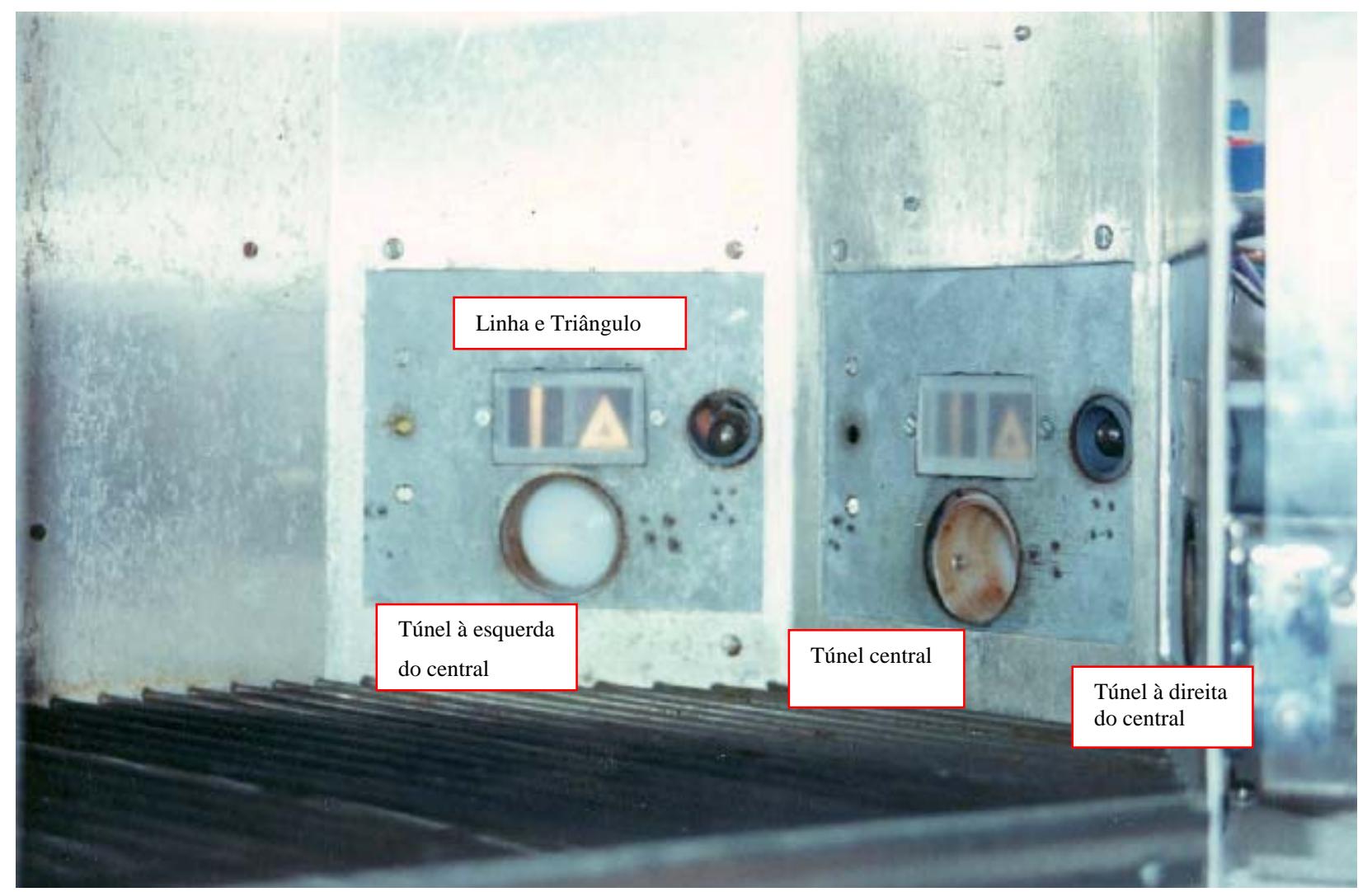

Figura 2. Fotografia da caixa utilizada no estudo de discriminação complexa com os 3 túneis e detalhes dos estímulos linha e triângulo apresentados sobre os túneis

\subsection{Procedimento do treino da discriminação}

\section{Procedimentos iniciais}

Na sessão inicial, foram reforçadas as respostas de nose poken no túnel central até completar 100 reforços (CRF) e na sessão seguinte foi realizada a modelagem da resposta de pressão à barra. Cada resposta de aproximação à barra foi reforçada manualmente (acionamento de uma tecla do teclado) no túnel central até completar 120 reforços (CRF) durante 2 sessões consecutivas. Em seguida, foi iniciado o treino da discriminação.

\section{Treino da Discriminação}

Em cada tentativa, as respostas de pressão à barra foram seguidas da apresentação dos estímulos linha e triângulo em qualquer um dos três túneis, sendo que 1 dos túneis ficava sem 
estímulo. A resposta de nose poken no túnel com o estímulo linha vertical foi reforçada e as respostas no túnel com o estímulo triângulo ou sem estímulo não foram reforçadas. Após a resposta de nose poken em um dos 3 túneis a tentativa foi encerrada. Uma nova resposta de pressão à barra iniciava outra tentativa. A posição dos estímulos sobre cada um dos túneis foi aleatória.

Em todas as fases do experimento foram realizadas sessões de 120 tentativas e utilizado o procedimento de não correção do erro, isto é, os estímulos foram desligados após qualquer resposta nos túneis e na tentativa seguinte os estímulos foram apresentados em posições diferentes da tentativa anterior. O treino foi prolongado para cada sujeito até que o número de acertos fosse igual ou superior a $80 \%$ em 3 sessões consecutivas (o que corresponde 96 acertos em 120 tentativas) ou até um total de 60 sessões na discriminação e reversão da discriminação e 70 sessões na condicional. Após a obtenção do critério de acertos ou o número fixo de sessões descrito acima foi iniciada a reversão da discriminação.

\subsection{Reversão da discriminação}

Após a resposta de pressão à barra, os estímulos linha e triângulo foram apresentados em qualquer um dos três túneis, sendo que em um dos túneis ficava sem estímulo.

Nesta fase, as respostas de nose poken foram reforçadas no túnel com o estímulo triângulo e não foram reforçadas nos demais túneis. A posição dos estímulos sobre cada um dos túneis foi aleatória. Após a obtenção do critério de acertos ou o número fixo de sessões descrito acima foi iniciado o treino da discriminação condicional. 


\subsection{Discriminação condicional}

Nesta fase, após a resposta de pressão à barra, os estímulos condicionais (SC) som constante ou interrompido (alternados a cada 30 tentativas) foram apresentados através de um auto-falante localizado dentro do túnel central juntamente com os outros estímulos linha e triângulo (apresentados logo acima de qualquer um dos túneis). Durante a apresentação do som constante, a resposta de nose poken foi reforçada no túnel com o estímulo linha e as respostas nos demais túneis não foram reforçadas.

Durante a apresentação do som interrompido a resposta de nose poken foi reforçada no túnel com o estímulo triângulo e as respostas nos demais túneis não foram reforçadas.

A localização dos estímulos linha e triângulo em cada tentativa era aleatória. Os estímulos condicionais e os $\mathrm{S}^{\mathrm{Ds}}$ estão descritos na Tabela 3.

Após o reforço em cada tentativa, uma nova tentativa somente era iniciada após uma nova resposta de pressão à barra.

Tabela 3. Indicação dos estímulos condicionais (SC) e dos estímulos que sinalizavam as respostas corretas $\left(\mathrm{S}^{\mathrm{D}}\right)$ ou incorretas $\left(\mathrm{S}^{\Delta}\right)$, nas tentativas sucessivas do treino da discriminação condicional

\begin{tabular}{ccc}
\hline Estímulo condicional (SC) & Resposta correta $\left(\mathbf{S}^{\mathbf{D}}\right)$ & ${\text { Resposta incorreta }\left(\mathbf{S}^{\Delta}\right)}^{\text {som constante }}$ \\
som interrompido & linha & triângulo ou nenhum \\
& triângulo & linha ou nenhum \\
\hline
\end{tabular}




\subsection{Análise Estatística}

Os dados de peso corporal e ingestão de dieta dos animais do Experimento 1 foram submetidos a uma Análise de Variância (ANOVA) de 2 fatores (dieta x dias), com medida repetida no fator dia, seguida de uma análise post-hoc usando o teste Newman-Keuls. Os dados de peso corporal e ingestão de dieta dos animais do Experimento 2 foram submetidos a uma ANOVA de 3 fatores (dieta x estimulação x dia), com medida repetida no fator dia, seguida da análise post-hoc usando o teste de Newman-Keuls.

Todos os dados comportamentais dos Experimentos 1 e 2 foram submetidos a uma análise não paramétrica por não apresentarem uma distribuição normal como apontada pelo teste de normalidade Shapiro-Wilk's W test.

Os índices de discriminação e reversão do Experimento 1 foram submetidos a uma análise utilizando o teste de Kruskal-Wallis, com medida repetida no fator sessão utilizando o teste de Friedman. As respostas por segundo entre os grupos $\left(S^{D}\right.$ e $\left.S^{\Delta}\right)$ da discriminação e reversão foram submetidas ao teste de Kruskal-Wallis seguidas por uma análise de comparação de 2 amostras independentes utilizando o teste de Mann-Whitney. As respostas por segundo do desempenho de cada grupo separadamente durante as 6 sessões da discriminação com a sessão 1 da reversão foram analisadas pelo teste de Wilcoxon.

Os dados do experimento 2 de freqüência de acertos, duração da tentativa e intervalo entre tentativas entre grupos foram submetidos ao teste de Kruskal-Wallis seguidas por uma análise de comparação de 2 amostras independentes utilizando o teste de Mann-Whitney.

Foi considerado como nível de significância um valor de $\mathrm{p}<0,05$. Para a análise dos dados foi utilizado o programa Statistics , versão 5.0.

* A escolha das provas estatísticas foi realizada com a assessoria do Prof. Dr. Sebastião de Sousa Almeida, docente do Departamento de Psicologia e Educação da Faculdade de Filosofia, Ciências e Letras de Ribeirão Preto - USP- SP, Brasil. 


\subsection{RESULTADOS}

\section{Experimento 1}

\subsection{Peso corporal}

Na análise dos pesos das ratas-mãe durante os 21 dias da lactação (Figura 3), a ANOVA mostrou um efeito significativo do fator dieta [F $(1,4)=1,16 ; \mathrm{p}<0,05]$, do fator dia $[F(3,12)=59,70 ; p<0,05]$ e uma interação entre os fatores dieta $x$ dia $[F(3,12)=12,97 ; p<$ $0,05]$.

A análise de comparações múltiplas mostrou que os pesos das ratas desnutridas foram menores nos dias 14 e 21 em relação aos pesos das controles, ainda que no dia 1, os pesos das desnutridas tenham sido maiores que os pesos das controles $(\mathrm{p}<0,05)$. Deve ser salientado que a designação das ratas no dia 1 para cada condição de dieta foi ao acaso.

Peso corporal das ratas-mãe - lactação

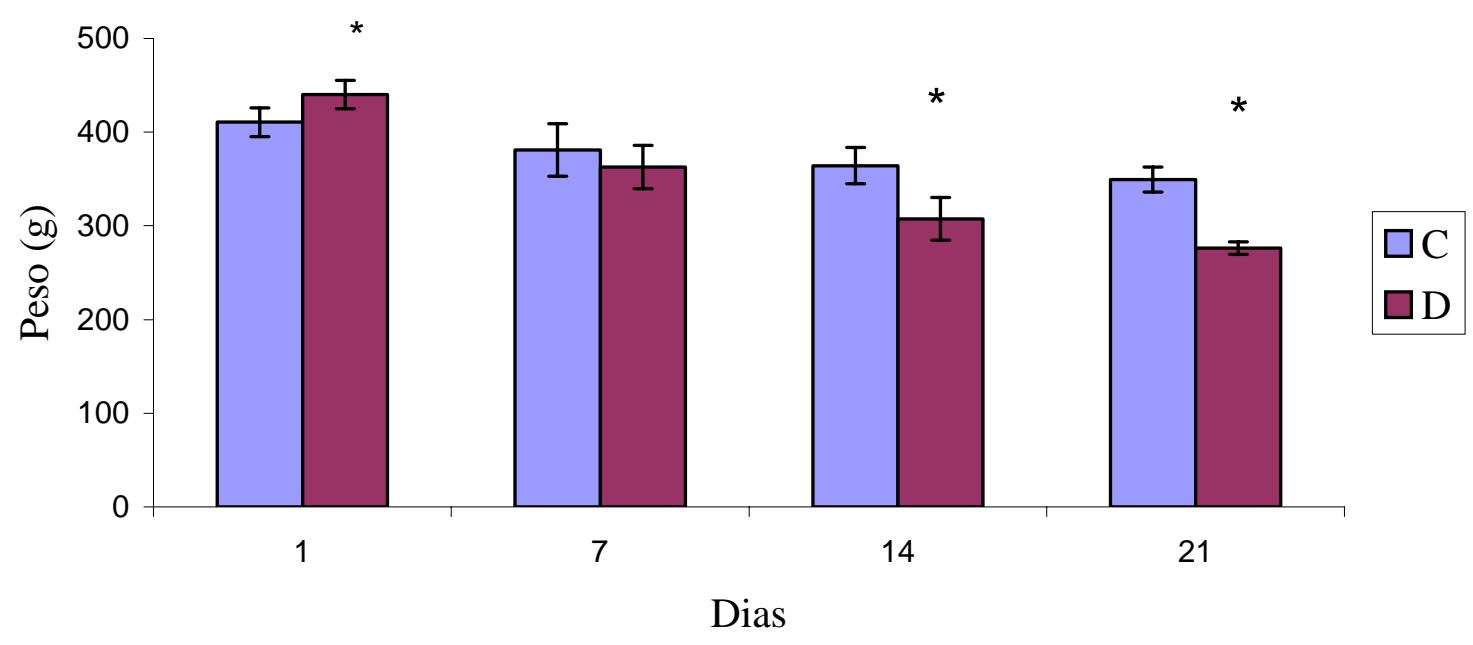

Figura 3. Peso corporal das ratas-mãe Controle (C) $(n=6)$ e Desnutrida (D) $(n=6)$ durante a lactação (1-21 dias). As colunas representam os valores da média dos pesos e as barras verticais o Erro Padrão da Média (EPM). O asterisco indica diferença significativa em relação ao grupo controle no mesmo dia, ${ }^{*} p<0,05$ 
A análise dos pesos dos filhotes durante o período da lactação (Figura 4) mostrou efeito significativo do fator dieta $[F(1,4)=34,88$; $p<0,05]$, do fator dia $[F(3,12)=77,30$; $p<0,05]$ e uma interação entre os fatores dieta $\mathrm{x}$ dia $[\mathrm{F}(3,12)=28,08 ; p<0,05]$.

Pela análise de comparações múltiplas, os pesos dos filhotes controles foram maiores que os pesos dos filhotes desnutridos nos dias 14 e 21. No dia 21 da lactação, os pesos dos filhotes desnutridos (6 machos e 2 fêmeas) (171,83 g) foram aproximadamente 60\% menores em comparação com os pesos dos filhotes controles (472,83 g).

\section{Peso corporal dos filhotes - lactação}

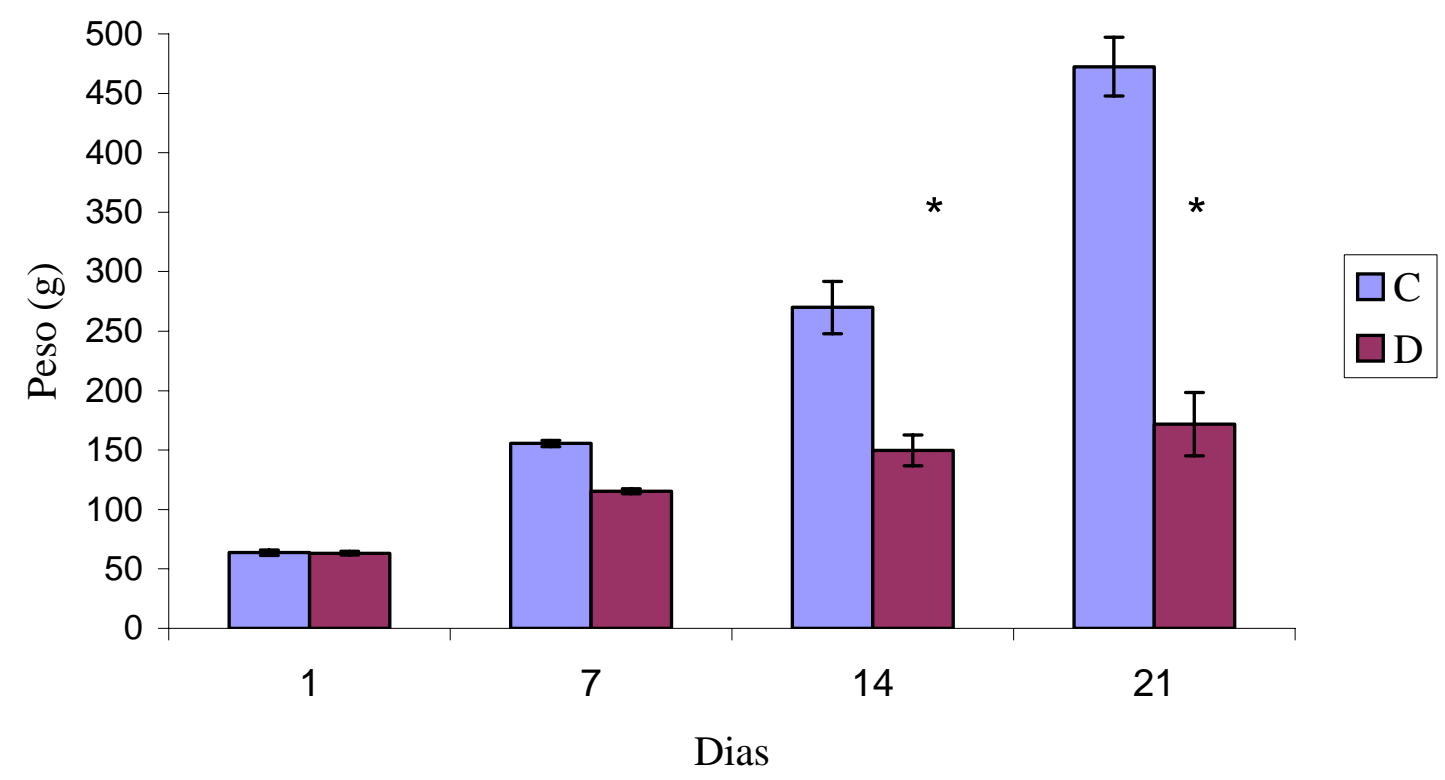

Figura 4. Peso corporal dos filhotes Controles (C) $(n=18)$ e Desnutridos (D) $(n=16)$ durante a lactação (1- 21 dias). As colunas representam os valores da média e as barras verticais o Erro Padrão da Média (EPM). O asterisco indica diferença significativa em relação ao grupo controle no mesmo dia, ${ }^{*} \mathrm{p}<0,05$

Em relação ao peso dos animais durante o período da pós-lactação (22 a 35 dias de idade) (Figura 5), a ANOVA mostrou um efeito significativo do fator dieta [F (14, 
462)=195,17; $p<0,05]$, do fator dia [F (1,33)=130,06; $p<0,05]$ e uma interação entre os fatores dieta $\mathrm{x}$ dia $[\mathrm{F}(14,462)=128,93 ; p<0,05]$.

A análise de comparações múltiplas revelou que as diferenças de pesos entre animais controles e desnutridos se mantêm nesse período, tendo os controles pesos maiores que os desnutridos dos 24 aos 35 dias de idade $(\mathrm{p}<0,05)$.

Peso corporal dos filhotes - pós-lactação

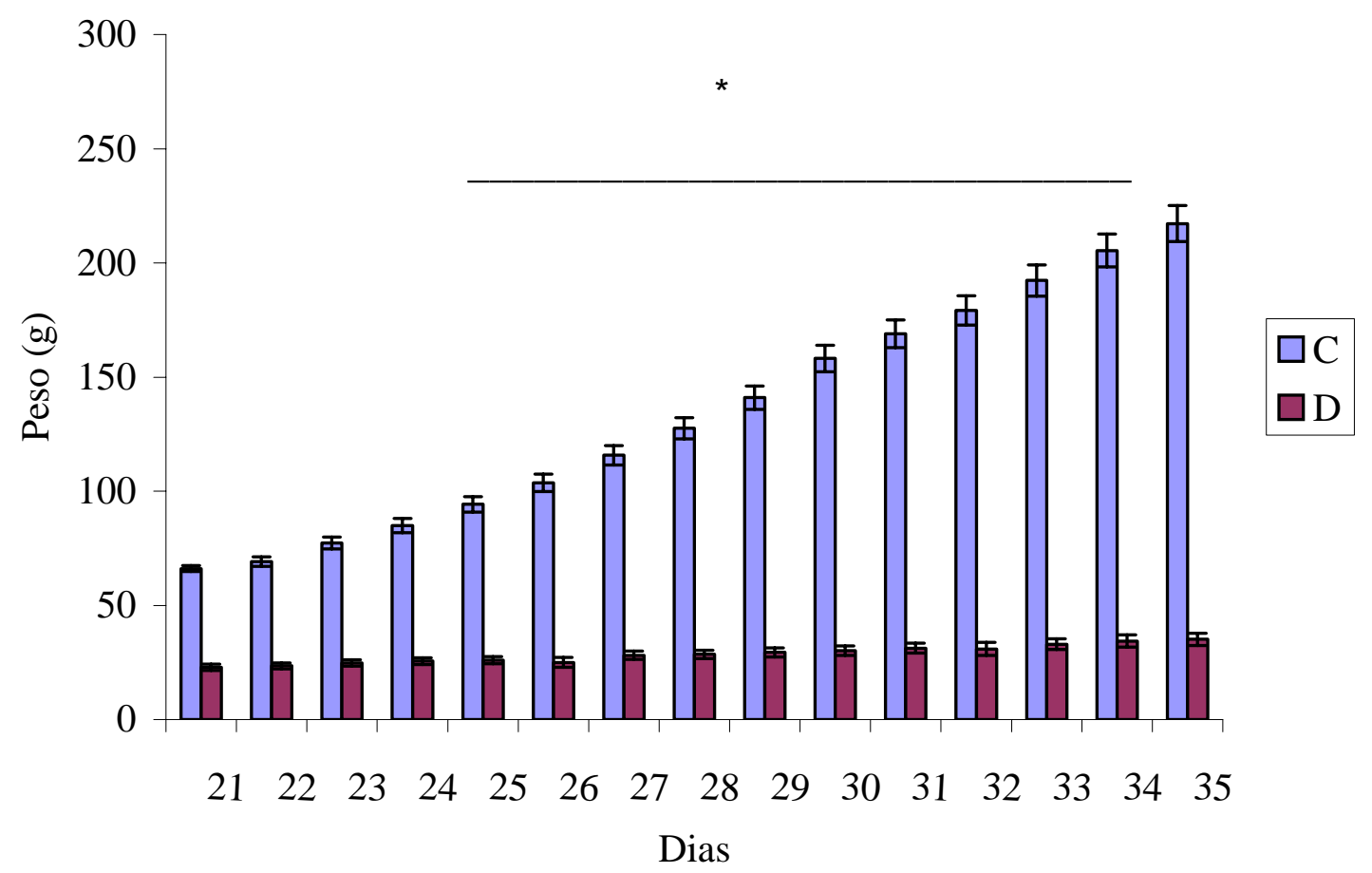

Figura 5. Peso corporal dos filhotes Controles (C) $(n=18)$ e Desnutridos (D) $(n=16)$ durante a pós-lactação (22-35). As colunas representam os valores da média e as barras verticais o Erro Padrão da Média (EPM). O asterisco indica diferença significativa em relação ao grupo controle no mesmo dia, dos 24 aos 35 dias de idade, ${ }^{*} \mathrm{p}<0,05$

Em relação aos pesos dos animais no período de 42 a 77 dias de idade (fase de recuperação alimentar para os desnutridos) (Figura 6), a análise mostrou um efeito significativo do fator dieta $[\mathrm{F}(9,297)=1268,5,17 ; p<0,05]$, do fator dia $[\mathrm{F}(1,33)=351,32$; $p<0,05]$ e uma interação significativa entre os fatores dieta $\mathrm{x}$ dia $[\mathrm{F}(9,297)=3,51 ; p<0,05]$. 
A análise de comparações múltiplas mostrou que as diferenças de pesos entre controles e desnutridos se mantêm dos 42 aos 77 dias de idade $(\mathrm{p}<0,05)$. Apesar de um crescente ganho de peso dos animais desnutridos, estes não chegaram a atingir os pesos dos controles. Aos 77 dias de idade, os pesos dos controles eram 509,08 g e dos desnutridos eram 307,72 g, apesar da disponibilidade de ração comercial e água à vontade para todos os animais.

Peso corporal dos animais - pós-lactação

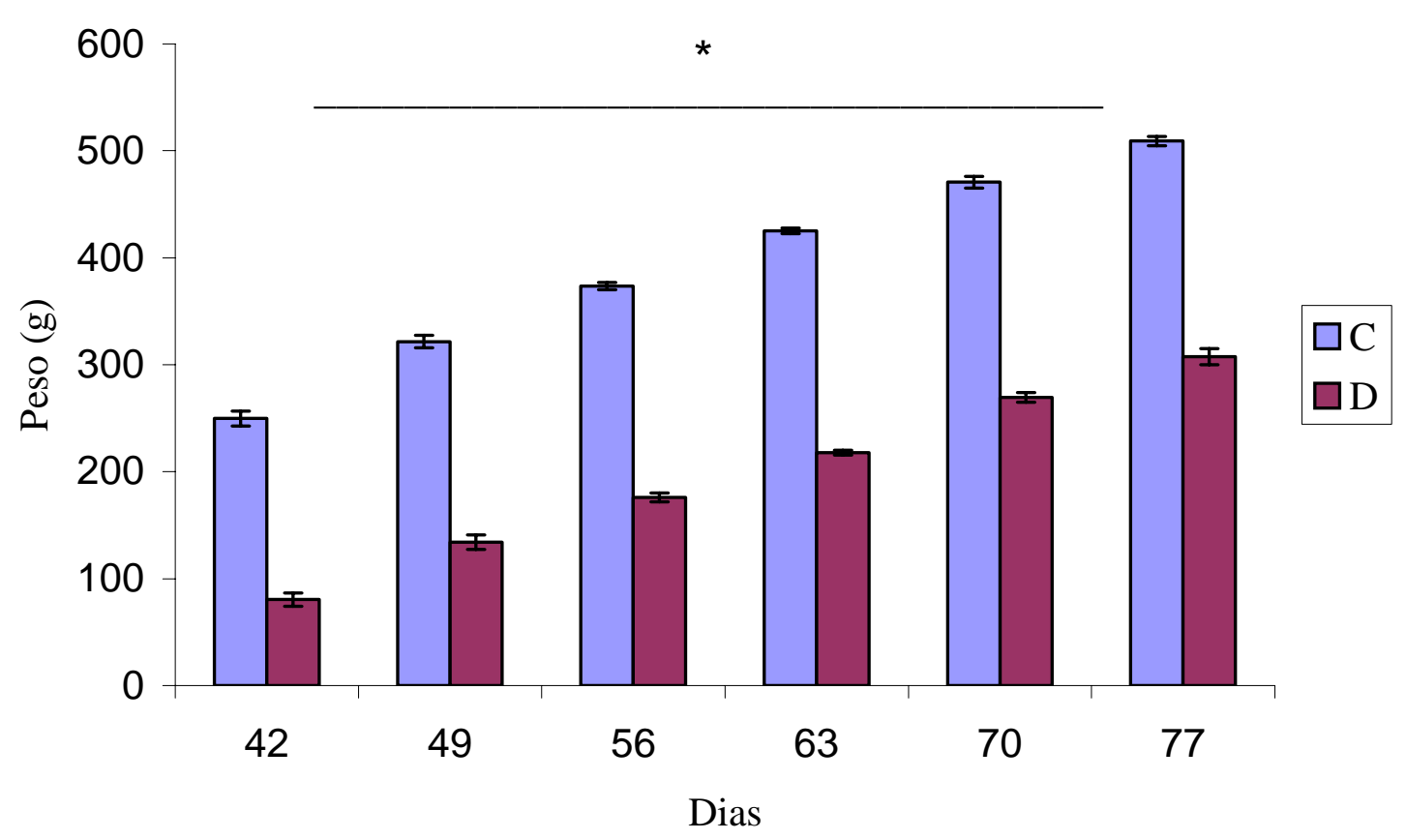

Figura 6. Peso corporal dos animais Controles (C) $(n=18)$ e Desnutridos ( D) $(n=16)$ durante a pós- lactação (42 a 77 dias). As colunas representam os valores da média e as barras verticais o Erro Padrão da Média (EPM). O asterisco indica diferença significativa em relação ao grupo controle no mesmo dia dos 42 aos 77 dias de idade, ${ }^{*} p<0,05$ 


\subsection{Ingestão de dietas}

Em relação à ingestão de dietas (16 ou 6\% de proteína) durante a lactação (1-21 dias) (Figura 7), a ANOVA apontou um efeito significativo do fator dieta [F $(19,76)=6,85 ; p<0,05]$ e do fator dia $[F(1,4)=22,5 ; p<0,05]$. Não houve efeito da interação dieta $\mathrm{x}$ dia [F (19, 76)=1,59; $p>0,05]$. A análise de comparações múltiplas apontou que os grupos diferiram na ingestão de dietas em todos os dias da lactação, com exceção dos 4 primeiros dias, tendo as ninhadas controles apresentado maior ingestão que as ninhadas desnutridas.

\section{Ingestão de dieta - lactação}

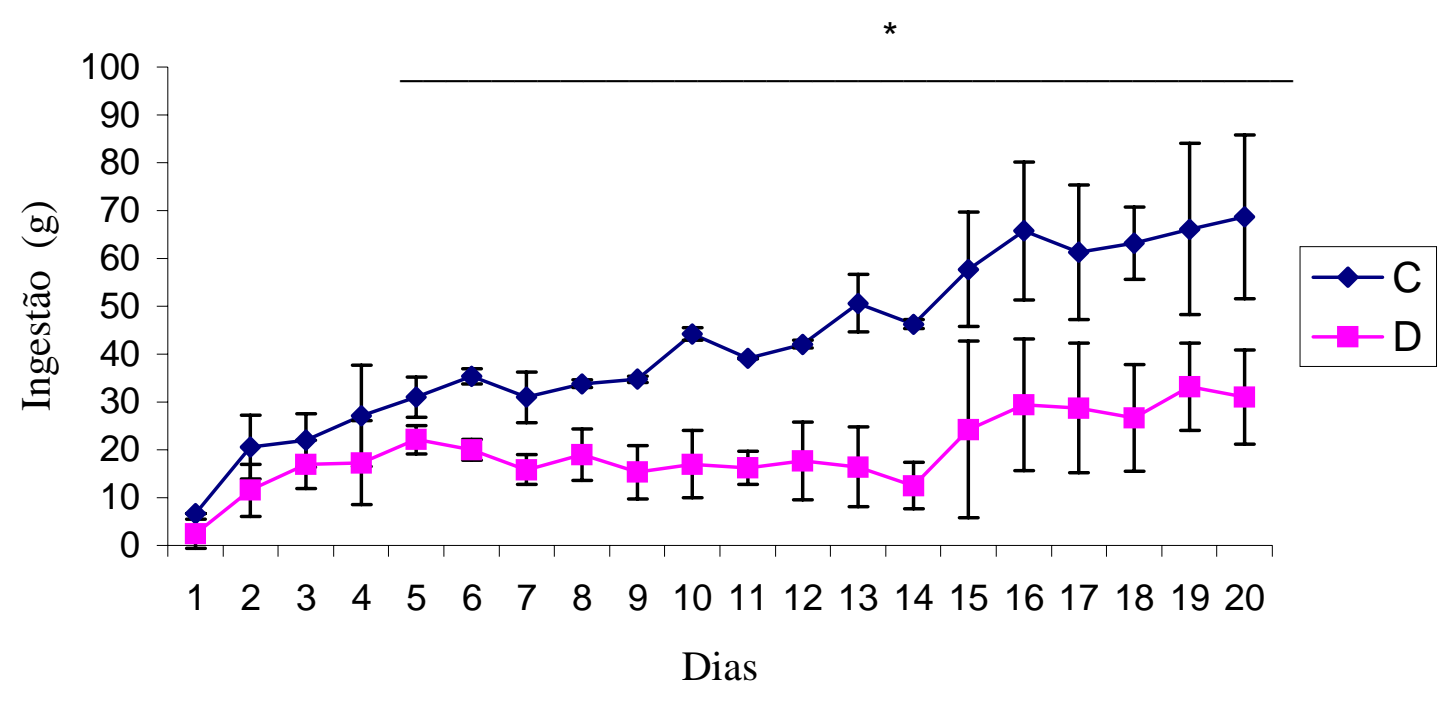

Figura 7. Ingestão de dietas das ninhadas controles $(C)(n=6)$ e desnutridas $(D)(n=6)$ durante a lactação (1-21). As colunas representam os valores da média e as barras verticais o Erro Padrão da Média (EPM). O asterisco indica diferença significativa do fator dieta e dia a partir do dia 4 em relação ao grupo controle, ${ }^{*} p<0,05$

Em relação à ingestão de dieta dos animais controles e desnutridos durante a póslactação (Figura 8), a ANOVA apontou um efeito significativo do fator dieta [F (13, 429)=15,98; $p<0,05]$, do fator dia $[F(1,33)=25,57 ; p<0,05]$ e uma interação entre os fatores dieta $\mathrm{x}$ dia $[\mathrm{F}(13,429)=2,59 ; p<0,05]$. 
A análise de comparações múltiplas mostrou que a ingestão de dietas foi menor para os filhotes desnutridos quando comparada a ingestão dos filhotes controles nos dias 25 a 34 desse período.

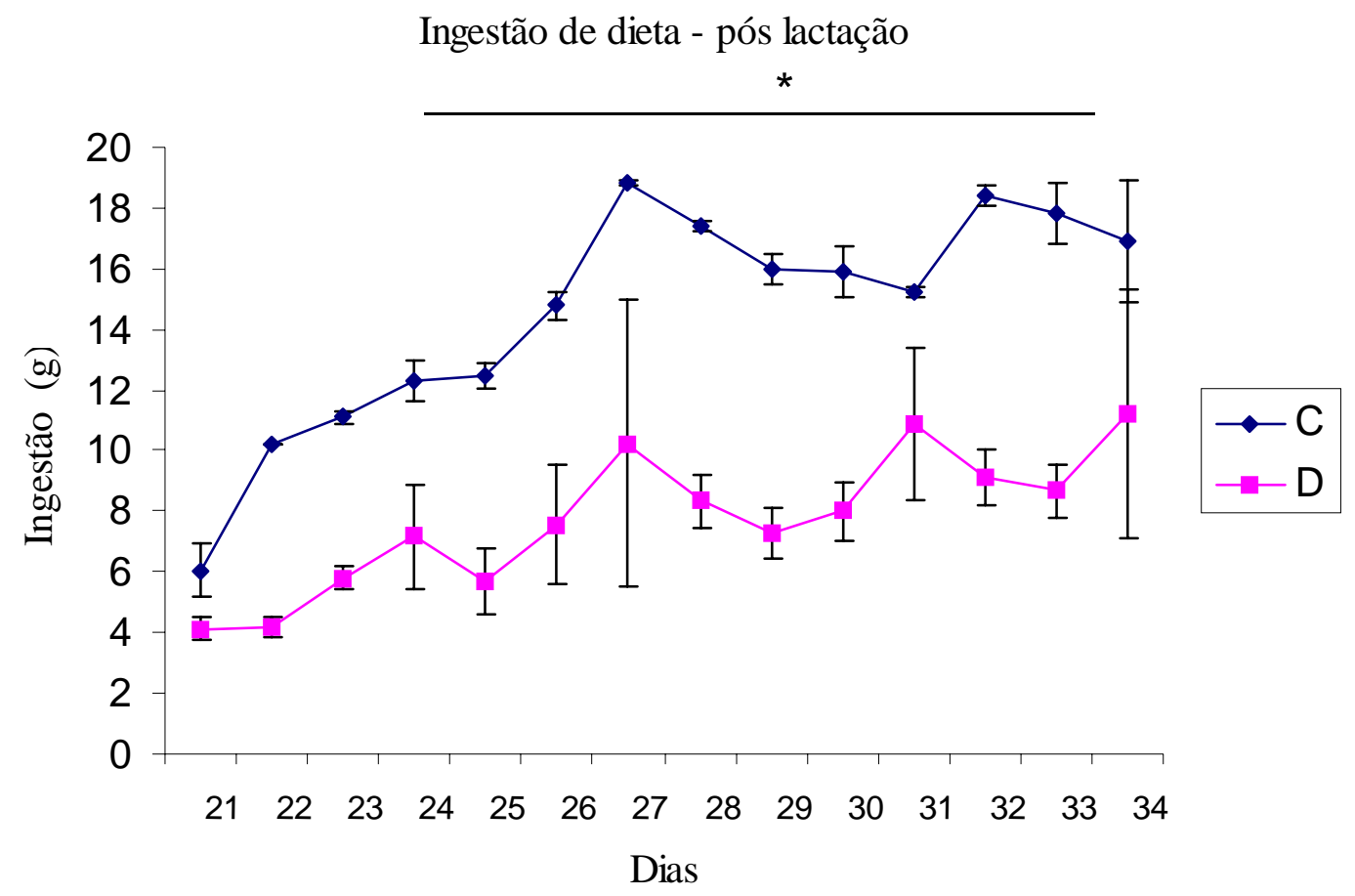

Figura 8. Ingestão de dieta dos Controles (C) $(n=18)$ e Desnutridos (D) $(n=16)$ durante a póslactação (21-34 dias). As colunas representam os valores da média e as barras verticais o Erro Padrão da Média (EPM). O asterisco indica diferença significativa em relação ao grupo controle no mesmo dia dos dias 25 a $34, *$ p $<0,05$

\subsection{Discriminação de luz ou som (experimento 1)}

Foi calculado o Índice de discriminação (ID) ao longo do treino de discriminação para cada sujeito em cada sessão do treino (sessões de 1 a 15) através da fórmula abaixo:

\section{$\underline{\text { Taxa de respostas durante o } S^{\underline{D}} \text { (estímulo discriminativo) } \times 100}$}

Taxa de respostas em $\mathrm{S}^{\mathrm{D}}+\mathrm{S}^{\Delta}$ (estimulo delta)

A análise estatística dos índices de discriminação não apontou diferenças para os fatores dieta e estímulo, mas foi significativa no fator sessão $(\mathrm{p}<0,05)$ [Figura 9- Parte Superior (CL/ DL) e Parte Inferior (CS / DS)]. 
Índice de discriminação
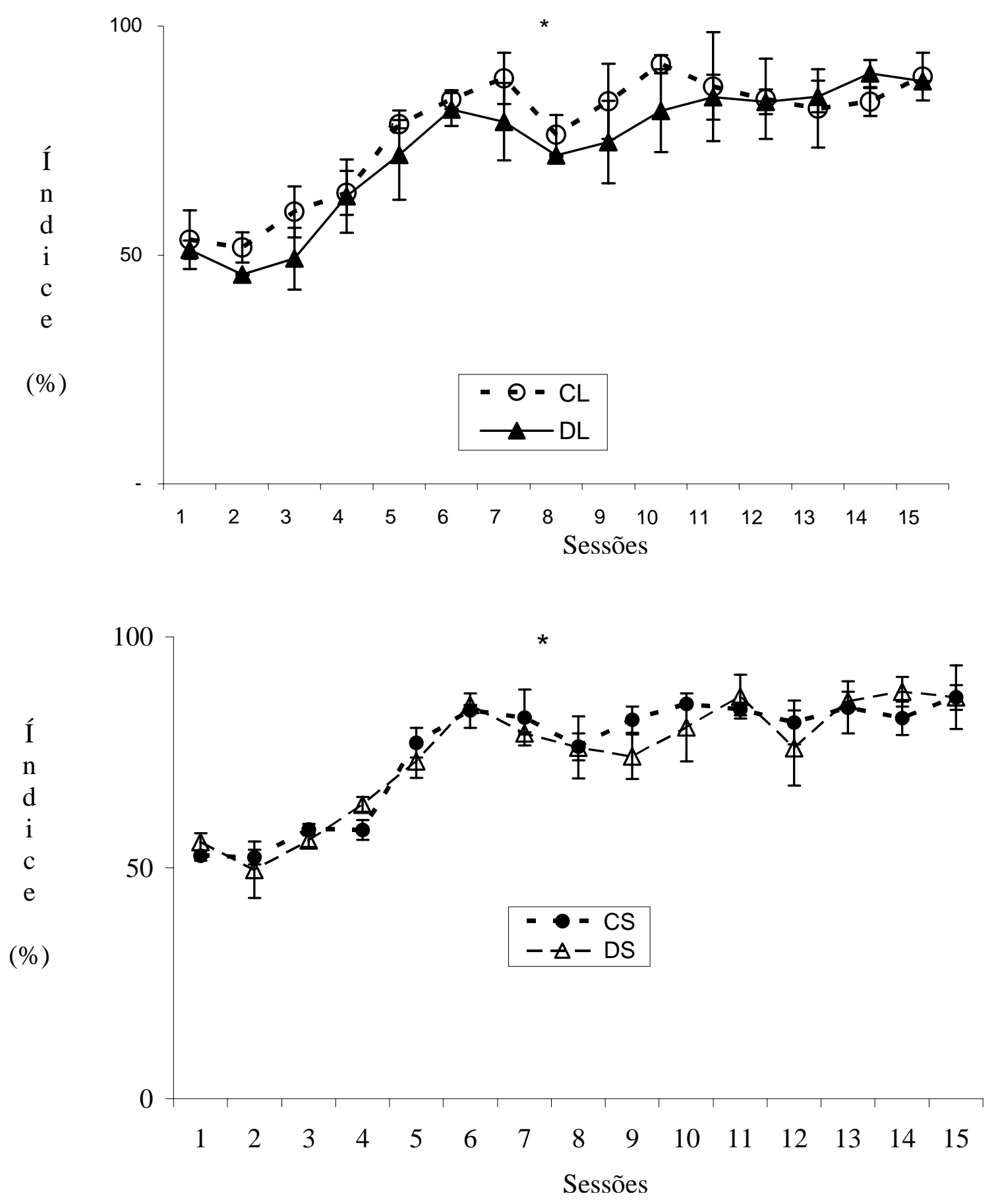

Figura 9. Índice de discriminação dos grupos Controle Luz (CL) e Desnutrido Luz (DL) (parte superior) e Controle Som (CS) e Desnutrido Som (DS) (Parte inferior), das sessões 1 a 15 da discriminação. As linhas representam os valores da média e as barras verticais o Erro Padrão da Média (EPM). O asterisco indica diferença no fator sessão, ${ }^{*} \mathrm{p}<0,05$ 
A Tabela 4, mostra uma comparação dos índices de discriminação dos sujeitos de cada grupo das 6 últimas sessões de treino (sessões 10, 11, 12, 13, 14 e 15) com os índices das 3 primeiras sessões da reversão (sessões 1, 2 e 3).

Tabela 4. Média do Índice de discriminação (\%) das 6 sessões finais da discriminação (10, 11, 12, 13, 14 e 15) e das 3 primeiras sessões (1, 2 e 3) da reversão para os grupos Controle Luz (CL), Desnutrido Luz (DL), Controle Som (CS) e Desnutrido Som (DS)

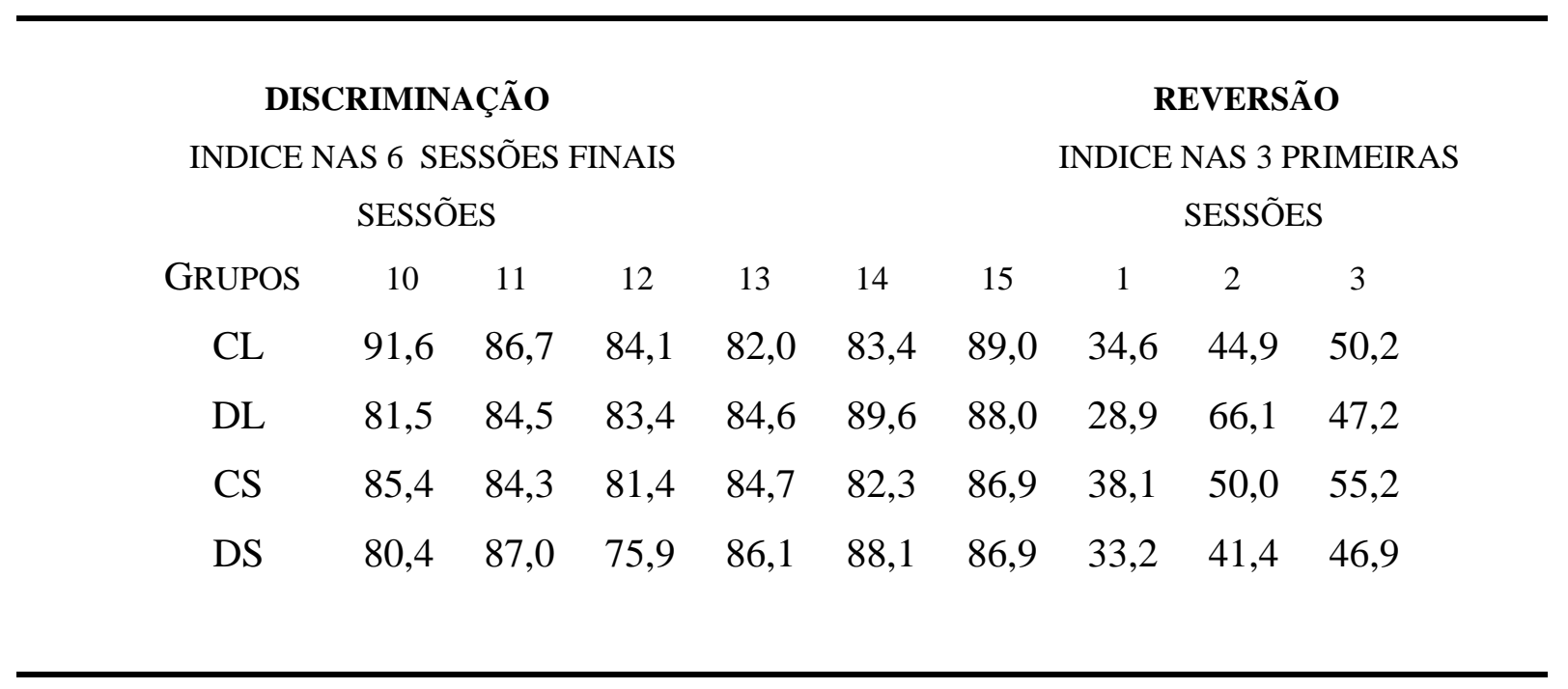

A análise dos índices na reversão mostrou um perfil semelhante ao da discriminação. Não houve diferenças significativas no fator dieta e estímulo, mas uma diferença significativa no fator sessão $(\mathrm{p}<0,05)$.

\subsection{Respostas por Segundo durante o $S^{D}$}

Não houve diferença de respostas por segundo entre os grupos nas 6 últimas sessões da discriminação Na reversão da discriminação, a análise da taxa (Respostas por Segundo) no $S^{\mathrm{D}}$ (sessões 1, 2 e 3) não mostrou diferenças entre grupos, com exceção do grupo CL que apresentou mais respostas que o DL na sessão 3. O desempenho de cada grupo nas sessões 1, 2 e 3 da reversão, em comparação com a linha de base da discriminação (6 últimas sessões) mostrou diferenças significativas para todos os grupos, com exceção do grupo DL nas sessões 2 e 3, como pode ser observado na Figura 10. 


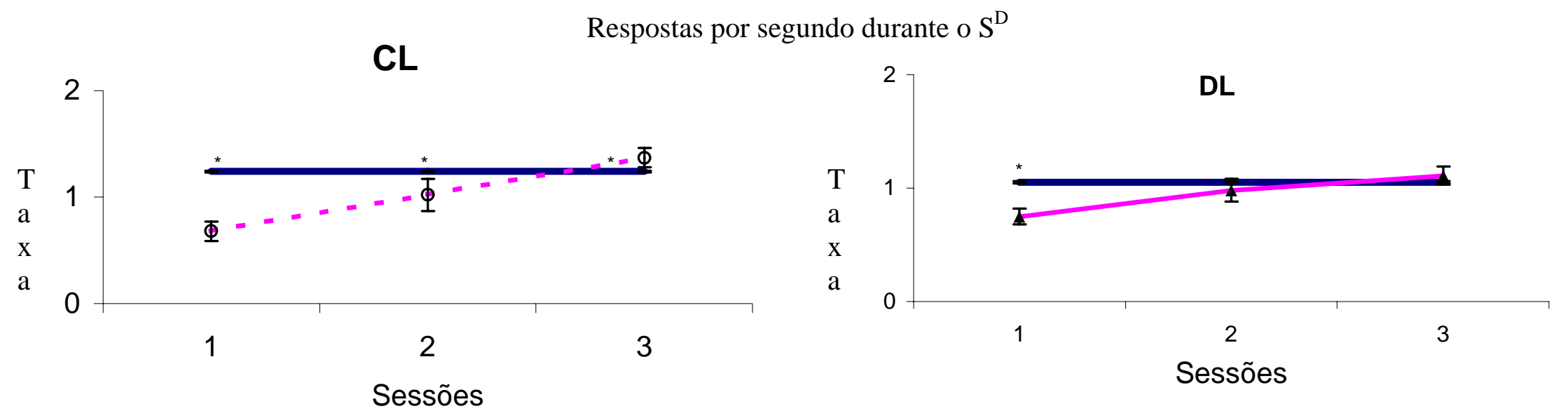

CS

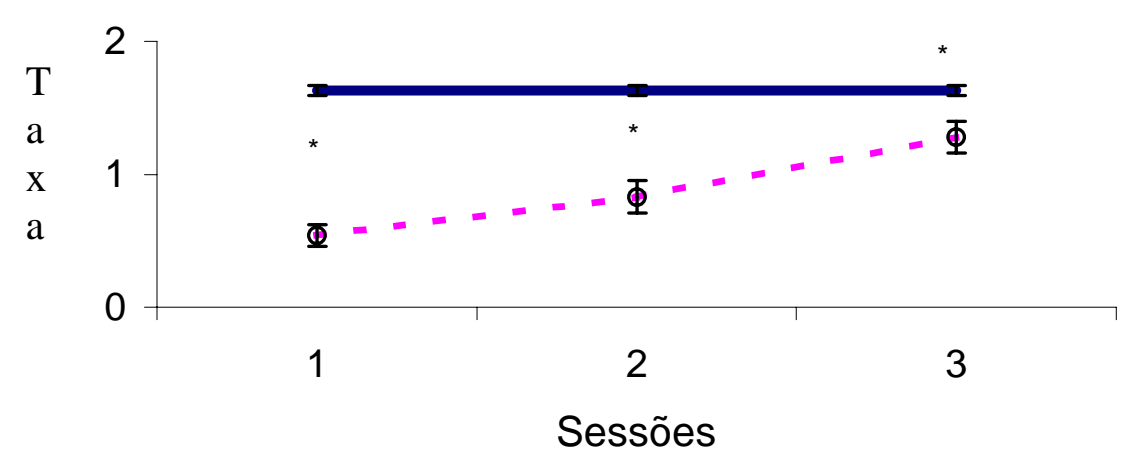

DS

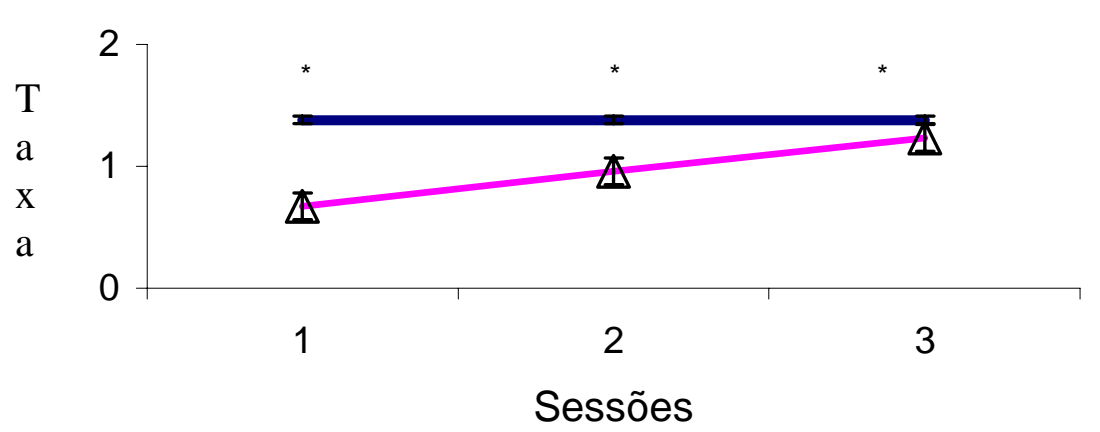

Figura 10. Respostas por segundo durante o estímulo discriminativo ( $\mathrm{S}^{\mathrm{D}}$ ) dos grupos Controle Luz (CL) e Desnutrido Luz (DL) (Parte Superior) e Controle Som (CS) e Desnutrido Som (DS) (Parte Inferior). As linhas cor de rosas representam os valores da media de respostas durante o $S^{\mathrm{D}}$ nas sessões 1 , 2, 3 da reversão em comparação com as linhas azuis que representam os valores da média das respostas por segundo durante as 6 sessões da discriminação. As barras verticais representam Erro Padrão da Média (EPM). O asterisco indica diferença significativa nas sessões da reversão $(1,2,3)$ em comparação com as 6 últimas sessões da discriminação $(10,11,12,13,14$ e 15), * p<0.05 


\subsection{Respostas por Segundo durante o $\mathrm{S}^{\Delta}$}

Não houve diferença significativa de respostas por segundo durante o $S^{\Delta}$ entre os grupos nas 6 últimas sessões da discriminação (linha de base).

A análise de Respostas por Segundo entre grupos durante o $\mathrm{S}^{\Delta}$ nas sessões 1, 2 e 3 da reversão não mostrou diferença significativa, com exceção do grupo CL que apresentou mais respostas que o DL nas sessões 2 e $3(\mathrm{p}<0,05)$.

A comparação do desempenho de cada grupo nas sessões 1, 2 e 3 da reversão com a linha de base da discriminação mostrou diferenças para todos os grupos $(p<0,05)$ com exceção do grupo DL na sessão 1 (Figura 11). 
Respostas po:

CL

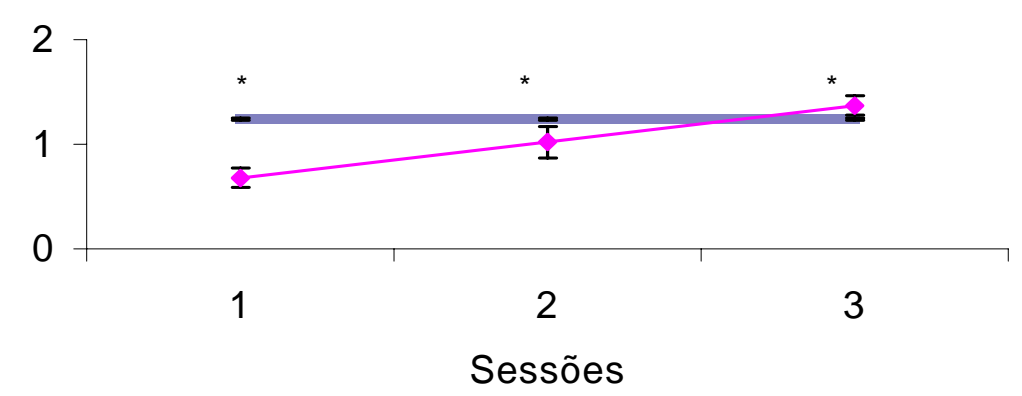

CS

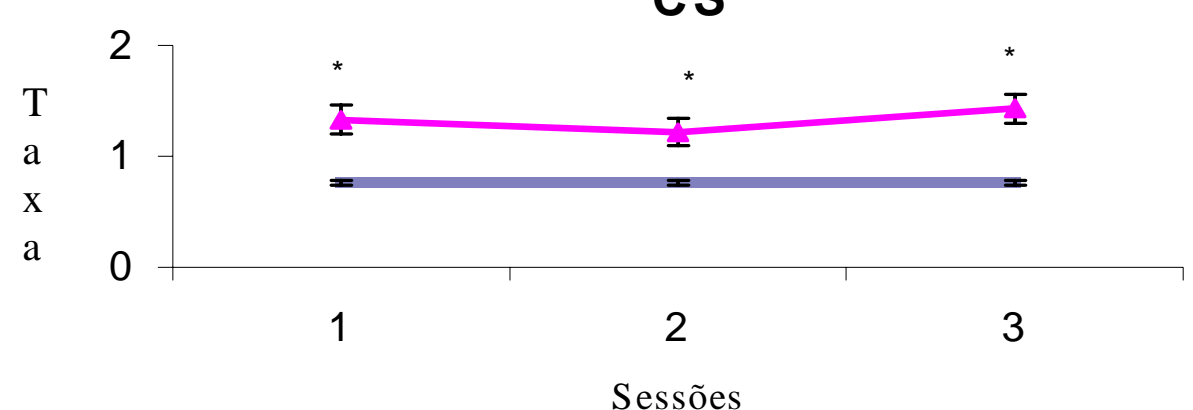

DL
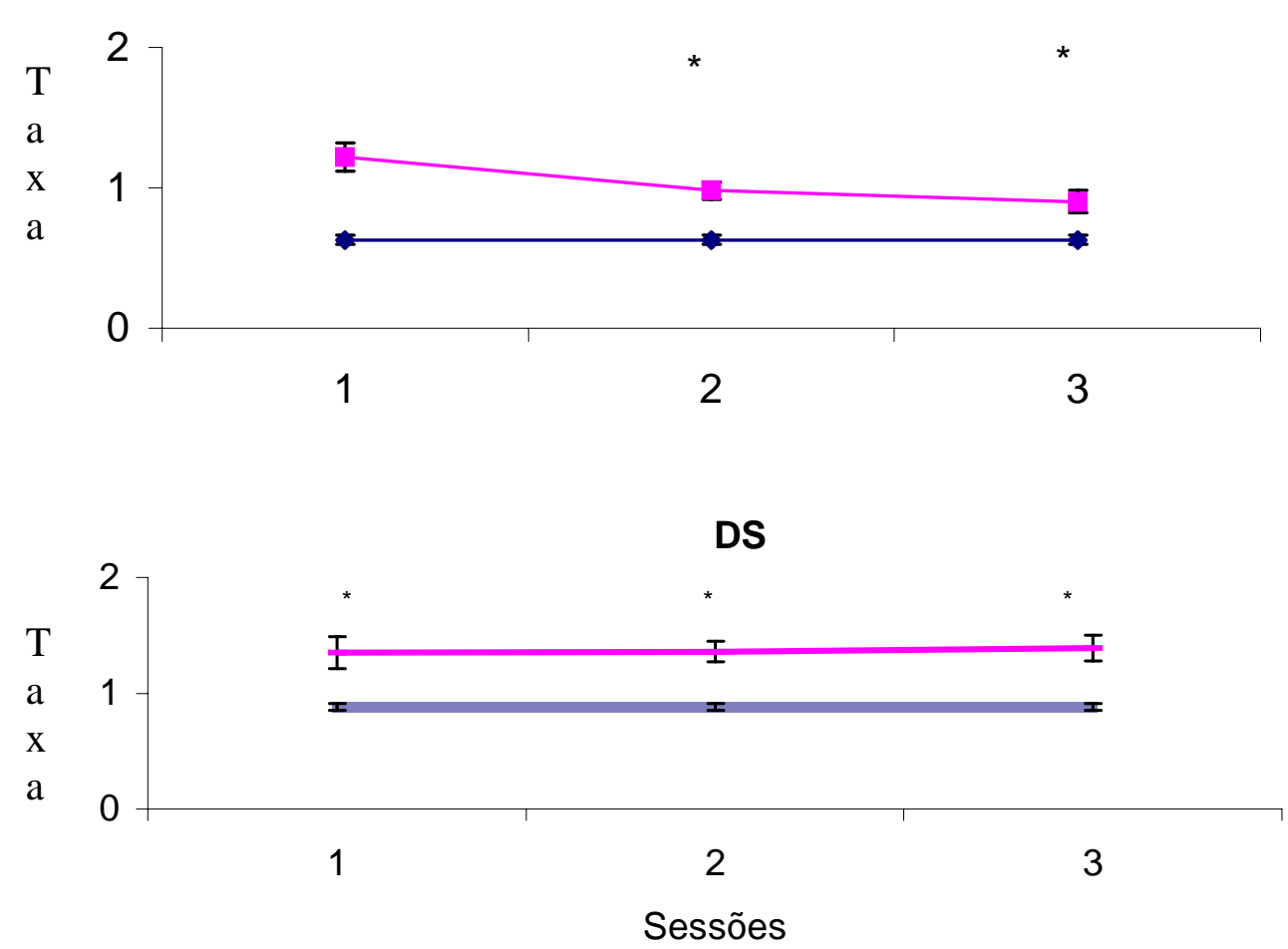

Figura 11. Respostas por segundo durante o estímulo delta $\left(\mathrm{S}^{\Delta}\right)$ dos grupos Controle Luz (CL) e Desnutrido Luz (Parte Superior) e Controle Som (CS) e Desnutrido Som (DS) (Parte Inferior). As linhas cor de rosas representam os valores da media de respostas durante o $S^{\mathrm{D}}$ nas sessões 1 , 2 , 3 da reversão em comparação com as linhas azuis que representam os valores da média de respostas por segundo durante as 6 sessões da discriminação. As barras verticais representam o Erro Padrão da Média (EPM) O asterisco indica diferença significativa nas sessões da reversão $(1,2,3)$ em comparação com as 6 últimas sessões $(10,11,12,13,14$ e 15) da discriminação, * p < 0,05 


\subsection{Experimento 2}

\subsection{Pesos corporais}

Com relação aos pesos das ratas-mãe durante o período de lactação (Figura 12), a ANOVA não mostrou um efeito significativo do fator dieta $[\mathrm{F}(1,15)=3,81 ; \mathrm{p}<0.05]$ e do fator estimulação $[F(1,15)=0,54 ; p<0,05]$, mas apontou um efeito do fator dia $[F(3,45)=132.32$; $\mathrm{p}<0,05]$ e uma interação entre os fatores dieta $\mathrm{x}$ dia $[\mathrm{F}(3,45)=32,92 ; \mathrm{p}<0.05]$.

A análise post hoc, mostrou que os pesos das ratas controles e desnutridas foram maiores no dia 21 em comparação ao dia 14, maiores no dia 14 do que no dia 7 e maiores no dia 7 maior em relação ao dia $1(p<0,05)$, sendo que entre o inicio e o fim da lactação as ratas controles perderam em média 11,7 \% enquanto que as desnutridas perderam 30,9 \% de seus pesos.

Os pesos das ratas controles foram maiores que os das desnutridas nos dias 7, 14 e 21, todavia, no dia 1 os pesos das desnutridas foram maiores do que os pesos das ratas controles $(\mathrm{p}<0,05)$, apesar da designação das ratas para cada condição de dieta ter sido ao acaso. 
Peso das ratas-mãe - lactação

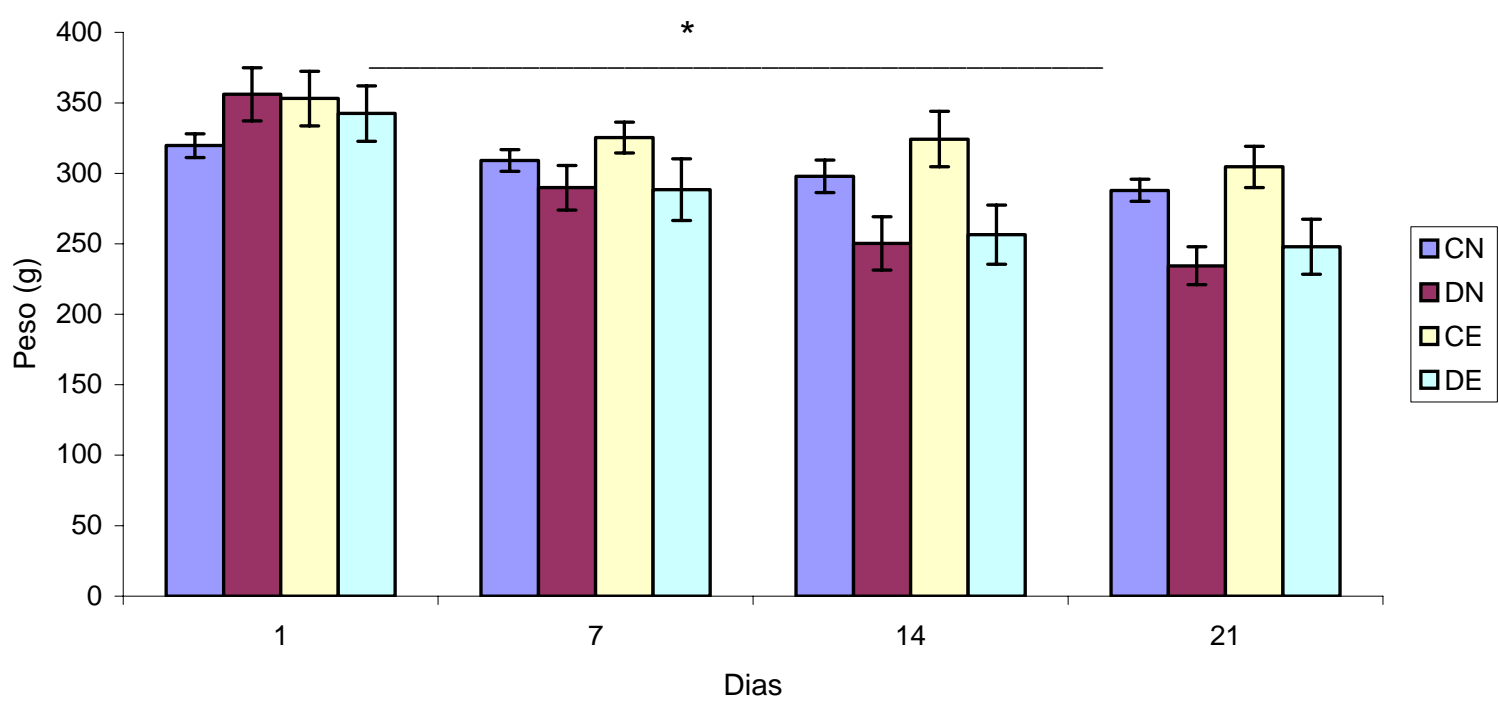

Figura 12. Peso corporal das ratas-mãe dos grupos Controle Não Estimulado (CN) (n=4), Desnutrido Não Estimulado (DN) ( $n=5)$, Controle Estimulado (CE) ( $n=5)$ e Desnutrido Estimulado (DE) $(n=5)$ durante a lactação (1-21dias). As colunas representam os valores da média pesos e as barras verticais o Erro Padrão da Média (EPM). O asterisco indica diferença significativa no fator dia e da interação dieta e dia, * $\mathrm{p}<0,05$

\section{Peso dos filhotes durante a lactação}

A análise dos pesos dos filhotes durante a lactação (Figura 13) apontou um efeito significativo do fator dieta $[F(1,15)=133,39 ; \mathrm{p}<0,05]$, do fator dia $[F(3,45)=270,19 ; \mathrm{p}<0,05]$, uma interação entre os fatores dieta $x$ dia $[F(3,45)=105.04 ; p<0,05]$, uma interação entre estimulação $\mathrm{x}$ dia $[\mathrm{F}(3,45)=4.42 ; \mathrm{p}<0,05]$ e uma interação dos fatores dieta $\mathrm{x}$ estimulação $\mathrm{x}$ dia $[F(3,45)=3.05 ; \mathrm{p}<0,05]$.

A análise post hoc mostrou que os pesos dos filhotes controles foram maiores que os dos desnutridos nos dias 7, 14 e 21 (p < 0,05). A comparação dos pesos dos controles nos dias 1 a 21 da lactação mostrou pesos maiores no dia 21 em comparação com o dia 14, maiores no dia 14 em relação ao dia 7 e maiores no dia 7 em comparação com o dia 1 $(\mathrm{p}<0,05)$. A comparação dos pesos dos desnutridos nos vários dias mostrou pesos maiores nos 
dias 14 e 21 em comparação com o dia 7 e maiores no dia 7 em relação ao dia 1 . Os pesos dos CN e CE foram maiores nos dias 21 do que no dia 14, maiores no dia 14 em relação ao dia 7 e maiores no dia 7 em relação ao dia $1(\mathrm{p}<0,05)$. Os pesos dos DN e DE foram maiores nos dias 7, 14 e 21 em comparação com o dia $1(\mathrm{p}<0,05)$. No último dia da lactação (dia 21) os pesos dos animais estimulados foram maiores do que os pesos dos animais não estimulados $(\mathrm{p}<0,05)$.

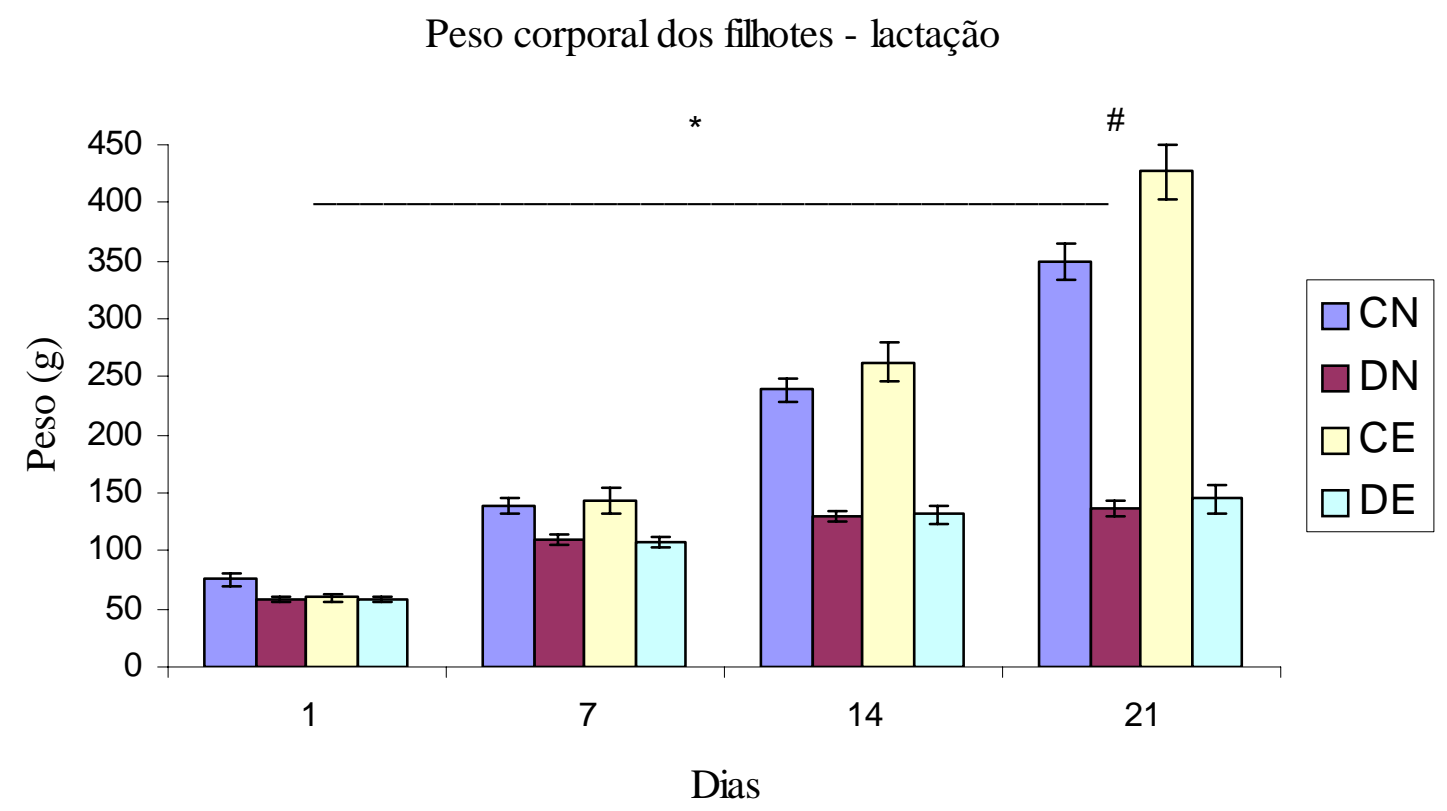

Figura 13. Peso corporal dos filhotes Controle não estimulado $(\mathrm{CN})(\mathrm{n}=4)$, Desnutrido não estimulado (DN) $(n=5)$ Controle estimulado (CE) $(n=5)$ e Desnutrido estimulado (DE) $(n=5)$ durante a lactação (1-21dias). As colunas representam os valores da média de peso e as barras verticais o Erro Padrão da Média (EPM). O asterisco indica diferença significativa no fator dieta e dia nos dias 7, 14 e 21 e o símbolo \# indica diferença significativa no fator estimulação no dia $21, * \# \mathrm{p}<0,05$ 


\section{Peso corporal dos animais durante a pós-lactação}

Em relação ao peso dos animais durante a pós-lactação, a ANOVA mostrou um efeito significativo do fator dieta $[F(1,18)=303,63 ; p<0,05]$, do fator dia $[F(2,36)=186.54 ; p<0,05]$ e uma interação entre os fatores dieta $x$ dia $[F(2,36)=119.54 ; p<0,05]$ evidenciando que as diferenças nos pesos entre C e D permanecem significativas ao longo do período de 21 a 35 dias (fase em que os C e D receberam as mesmas dietas da lactação) (Figura 14).

A análise post hoc mostrou que os animais controles pesaram mais que os desnutridos nos dias 21, 28 e 35 ( $p<0,05)$. Enquanto os controles aumentaram os pesos ao longo dos dias $(35<28<21)$, os desnutridos somente apresentaram pesos maiores no dia 35 em comparação com o dia $21(\mathrm{p}<0,05)$.

Como também pode ser observado na Figura 14, a ANOVA mostrou um efeito significativo do fator dieta $[\mathrm{F}=(1,17)=82,47 ; \mathrm{p}<0,05]$, do fator dia $[\mathrm{F}=(5,85)=325,40 ; \mathrm{p}<$ $0,05]$ e da interação dos fatores dieta $x$ dia $[\mathrm{f}=(1,85)=4,55 ; \mathrm{p}<0,05]$ em relação aos pesos dos animais durante a pós-lactação (dados de 42 aos 77 dias de idade).

A análise post hoc mostrou que os animais controles pesaram mais que os desnutridos nos dias 77, 63, 56, 49, 42 e $35(\mathrm{p}<0,05)$, apesar da disponibilidade de ração comercial à vontade para todos os animais. 


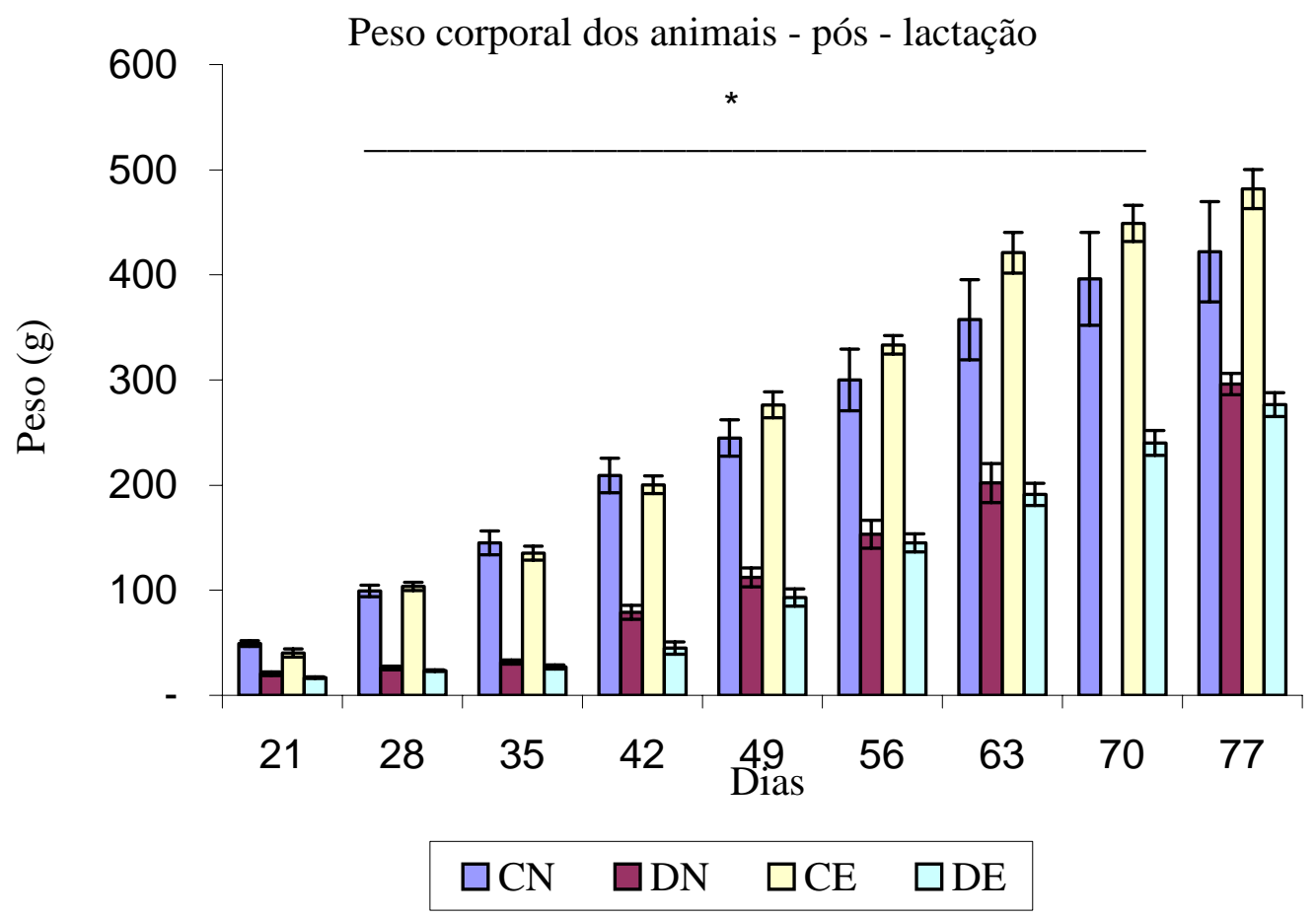

Figura 14. Peso corporal dos animais Controle não estimulado $(\mathrm{CN})(\mathrm{n}=4)$, Desnutrido não estimulado (DN) ( $n=5)$, Controle estimulado (CE) $(n=5)$ e Desnutrido Estimulado (DE) durante a pós-lactação (21-77dias). As colunas representam os valores da média e as barras verticais o Erro Padrão da Média (EPM). O asterisco indica diferença significativa no fator dieta e dia dos 21 a 77 dias, ${ }^{*} \mathrm{p}<0,05$

\subsection{Ingestão de dietas}

Em relação à ingestão de dietas (16 ou 6\% de proteína), durante a lactação, a ANOVA apontou um efeito significativo do fator dieta $[F=(1,15)=75,77 ; \mathrm{p}, 0,05]$, do fator dia $[F=(19,28)=18,20 ; p<0,05]$ e da interação entre os fatores dieta $x$ dia $[F=(19,285) ; p<0,05]$. A análise post hoc mostrou que a ingestão de dieta foi maior nos animais controles em comparação com os desnutridos a partir do dia 7 deste período $(\mathrm{p}<0,05)$ (Figura 15) 

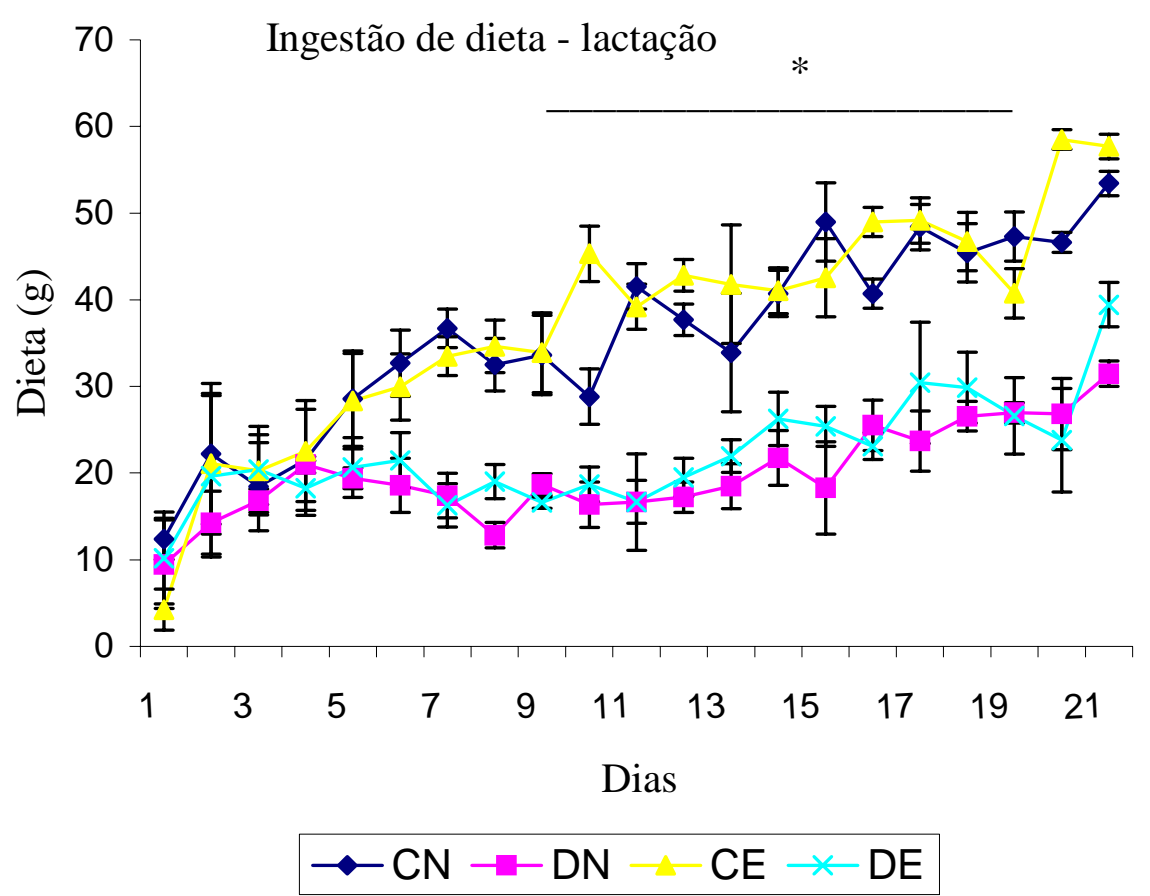

Figura 15. Ingestão de dietas das ninhadas Controle não estimulada $(\mathrm{CN})(\mathrm{n}=4)$, Desnutrida não estimulada (DN) - $(n=5)$, Controle Estimulada (CE) $(n=5)$ e Desnutrida estimulada (DE) $(n=5)$ durante a lactação 1-21 dias. As linhas representam os valores da média e as barras verticais o Erro Padrão da Média (EPM). O asterisco indica diferença significativa no fator dia e dieta a partir do dia $7, * \mathrm{p}<0,05$

\subsection{Treino da discriminação}

Na treino da discriminação (Figura 16), a análise mostrou um efeito de dieta quando se comparam os grupos CN, DN, CE e DE $(\mathrm{p}<0,05)$. Os animais $C N$ atingiram o critério (3 sessões consecutivas igual ou superior a $80 \%$ de acertos) mais rapidamente que os animais DN.

O efeito dieta é bem evidente quando se analisa o desempenho do DN onde a maioria dos sujeitos iniciou a reversão da discriminação sem ter atingido o critério de acertos. 
Número de sessões para atingir o critério - Discriminação

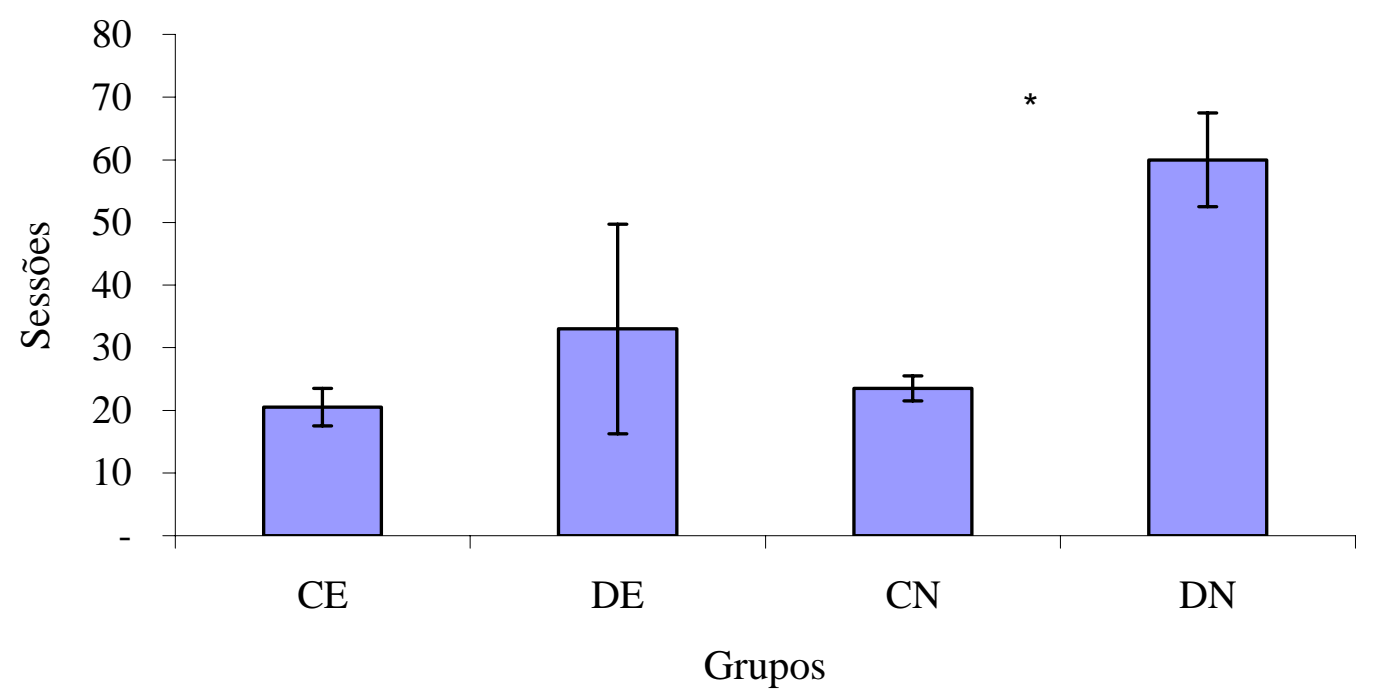

Figura 16. Número de sessões para atingir o critério na discriminação dos grupos Controle Não Estimulado (CN) $(n=6)$, Controle Estimulado (CE) $(n=6)$, Desnutrido Estimulado (DE) $(n=6)$ e Desnutrido Não Estimulado $(\mathrm{DN})(\mathrm{n}=6)$. As colunas representam os valores da mediana e as barras verticais o intervalo interquartil. $O$ asterisco indica diferença significativa, ${ }^{*} \mathrm{p}<0,05$

Foram realizadas sessões de treino até que o desempenho dos sujeitos atingisse o critério de no mínimo 80\% de acertos (96 acertos em 120 tentativas) durante 3 sessões consecutivas, antes de iniciar a reversão da discriminação. O quadro 1(ANEXO E) mostra o número de sessões para atingir o critério de acertos dos grupos Controle Estimulado (CE), Desnutrido Estimulado (DE), Controle Não Estimulado (CN) e Desnutrido Não Estimulado (DN) durante a discriminação (parte superior) e reversão da discriminação (parte inferior). 


\section{Acertos}

Em relação à freqüência de acertos, a análise não mostrou diferenças nas sessões 1 a 15 da discriminação (fase em que estavam todos os sujeitos em treino) $(\mathrm{CN}=7, \mathrm{DN}=6, \mathrm{CE}=6$ e $\mathrm{DE}=6)$.

Apesar disso, a Figura 17 mostra um aumento gradual de acertos para todos os grupos ao longo do treino (em torno de $40 \%$ de acertos na sessão 1 comparado a uma média de $80 \%$ de acertos nas últimas sessões), especialmente para os controles.

Nas últimas sessões de treino o desempenho dos DE e DN foi pior que o desempenho dos CE e CN. Foram necessárias mais sessões para os desnutridos atingirem o critério de acertos. Foram necessárias para os animais DN 60 sessões de treino, e mesmo assim, a maioria dos sujeitos não atingiu o critério.

Acertos- Discriminação

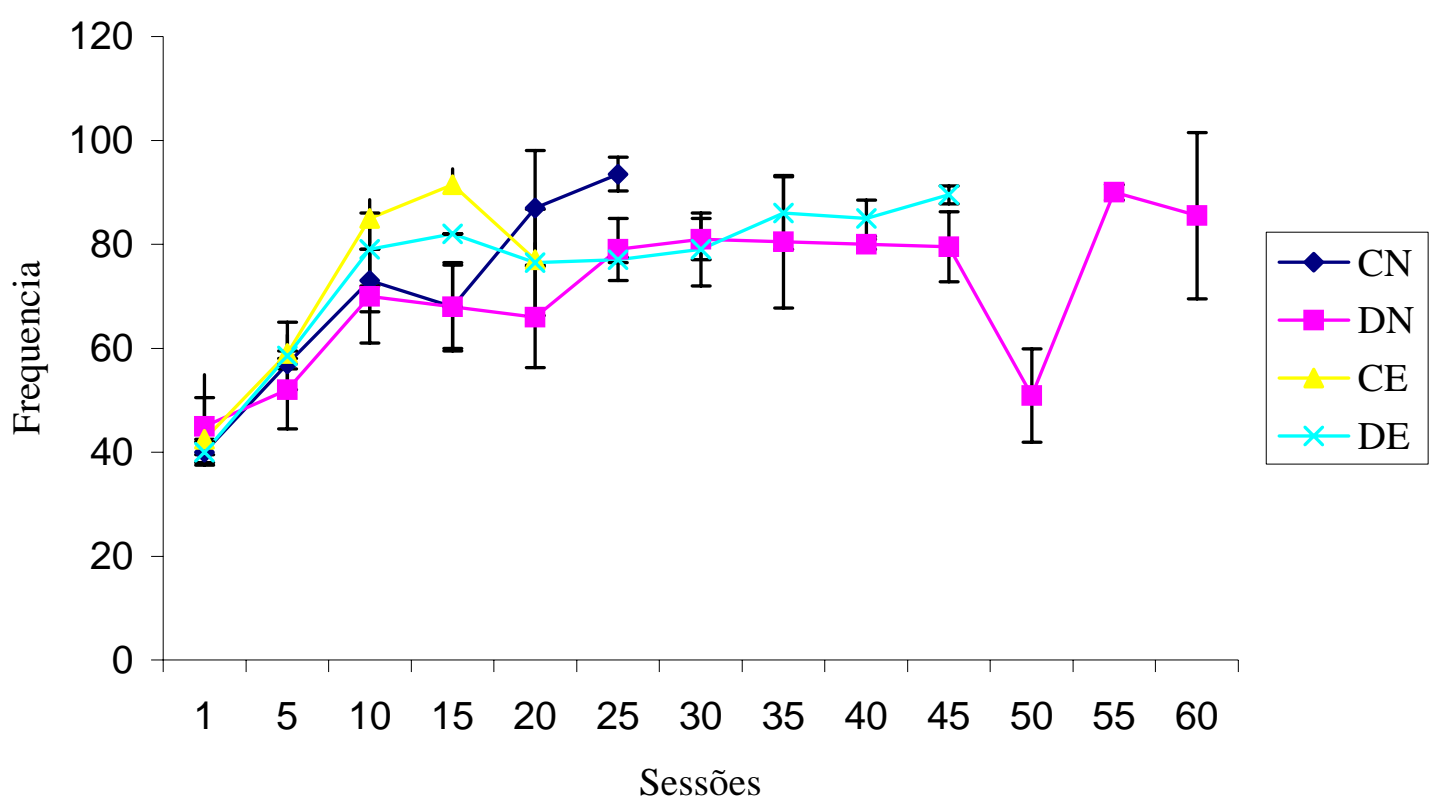

Figura 17. Freqüência de acertos dos grupos Controle Não Estimulado (CN) (n=6), Desnutrido Não Estimulado ( $n=6)$, Controle Estimulado (CE) $(n=6)$ e Desnutrido Estimulado (DE) (n=6). As linhas representam os valores da média e as barras verticais o Erro Padrão da Média (EPM) em blocos de 5 sessões 


\section{Duração da Tentativa}

A análise apontou um efeito significativo de dieta na sessão 1 do treino, onde a duração da tentativa foi menor para os DN em comparação ao CN ( $\mathrm{p}<0,05)$ (Figura 18).

A Figura 18 mostra uma oscilação da duração da tentativa na sessão 1 e intervalos de tempos maiores para os animais controles do que para os desnutridos.

Nas demais sessões, houve uma diminuição gradual da duração da tentativa para todos os grupos ao longo do treino, indicando um decréscimo do tempo para responder nos túneis onde foram apresentados os estímulos ( $\mathrm{S}^{\mathrm{D}}$ linha e $\mathrm{S}^{\Delta}$ triângulo).

Duração da tentativa- Discriminação

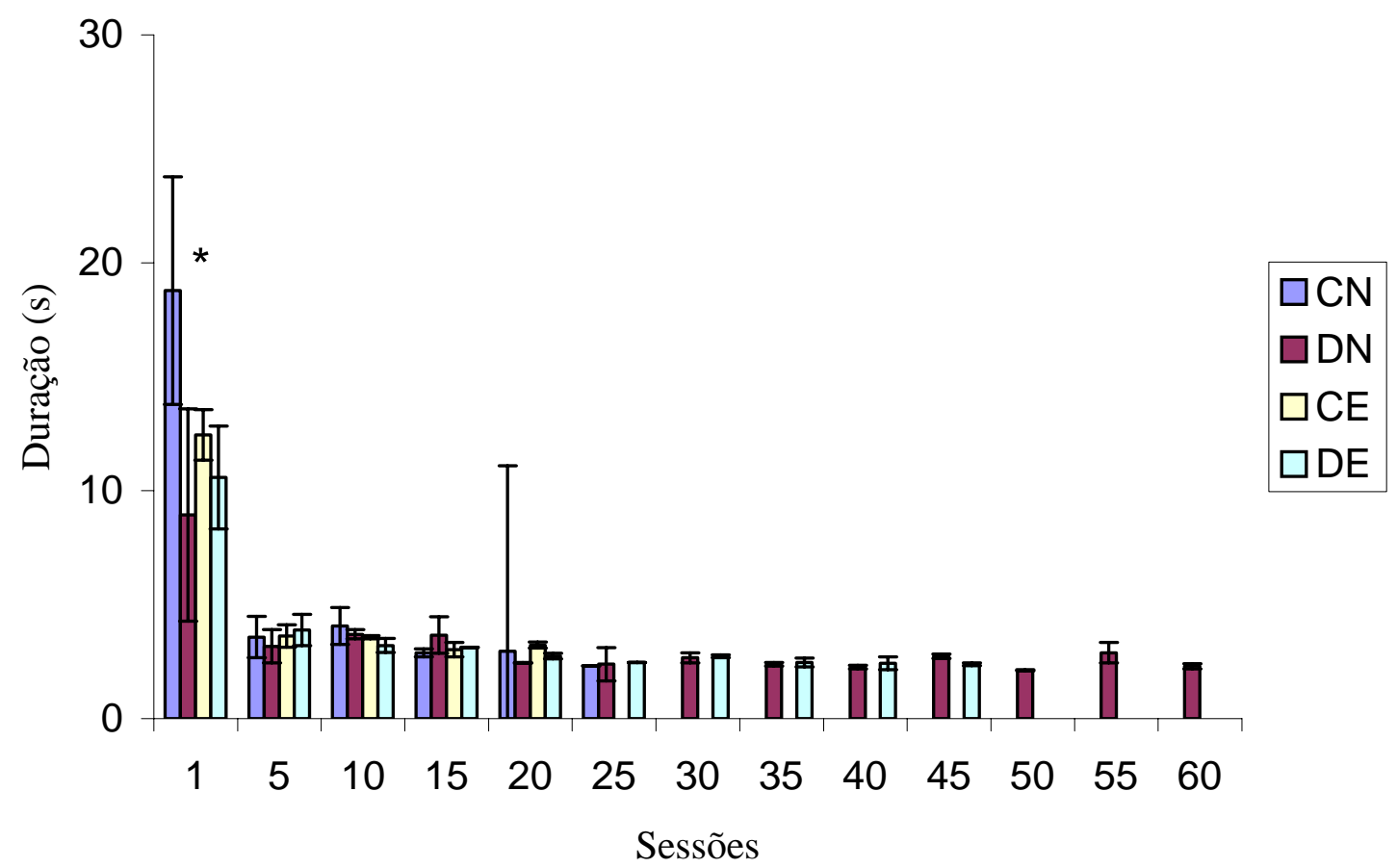

Figura 18. Duração da tentativa na discriminação dos grupos Controle Não Estimulado (CN) $(n=6)$, Controle Estimulado (CE) $(n=6)$, Desnutrido Estimulado (DE) (n=6) e Desnutrido Não Estimulado (DN) $(n=6)$. As colunas representam os valores da média e as barras verticais o Erro Padrão da Média (EPM) em blocos de 5 sessões. O asterisco indica diferença significativa $* \mathrm{p}<0,05$ 


\section{Intervalo Entre Tentativa}

A análise do Intervalo Entre Tentativa não apontou efeito de dieta e de estímulo para os grupos CN, DN, CE e DN. A Figura 19 também mostra uma maior oscilação de intervalos entre tentativas dos grupos na sessão 1 (intervalos maiores para os controles), enquanto que nas demais sessões os intervalos permanecem curtos e regulares (em torno de 15 s) para todos os grupos.

Intervalo entre Tentativa - Discriminação

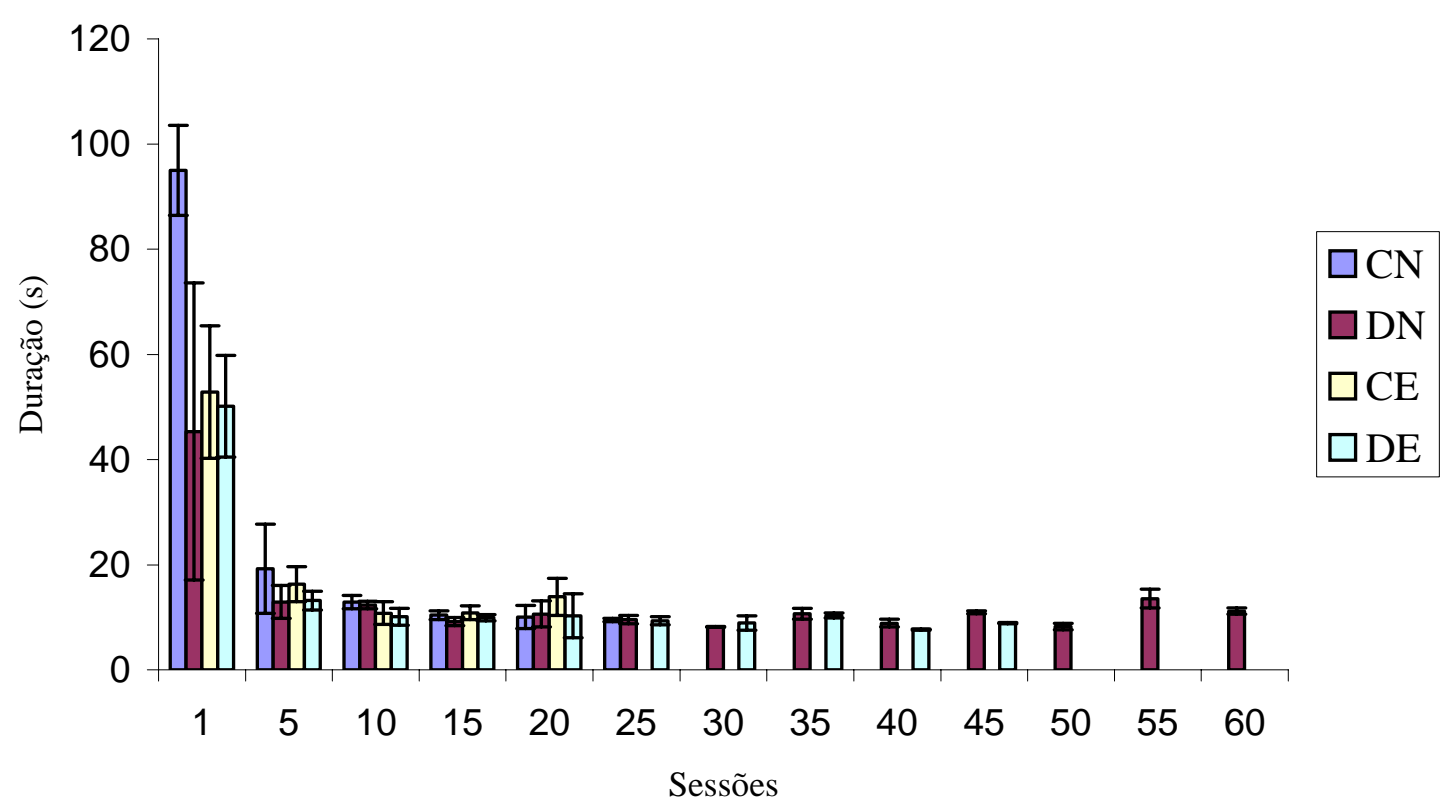

Figura 19. Intervalo Entre Tentativa durante o treino da discriminação dos grupos Controle Não Estimulado (CN) (n=6), Desnutrido Não Estimulado (DN) (n=6) Controle Estimulado (CE) $(n=6)$ e Desnutrido Estimulado (DE) $(n=6)$. As colunas representam os valores da média e as barras verticais o Erro Padrão da Média (EPM) em blocos de 5 sessões

\subsection{Reversão da discriminação}

\section{Número de sessões para atingir o critério}

Não houve efeito de dieta e de estímulo para atingir o critério de acertos na reversão 
( $p>0,05$ ), embora os animais DN tenham apresentado um desempenho pior em relação aos demais grupos (a maioria dos sujeitos não atingiu o critério de acertos nem com 60 sessões de treino), como pode ser observado no Quadro 2 a seguir. A Figura 20 mostra o número de sessões para atingir o critério nesta fase.

\begin{tabular}{|l|l|l|l|}
\hline CE & DE & CN & DN \\
\hline MÉDIANA= 51,0 & MÉDIANA= 48,0 & MÉDIANA= 44,0 & MÉDIANA= 59,5 \\
INTERQUARTIL= 18,5 & INTERQUARTIL= 2,5 & INTERQUARTIL= 6,0 & INTERQUARTIL= 3,5 \\
\hline
\end{tabular}

Quadro 2. Número de sessões para atingir o critério na reversão da discriminação dos grupos Controle Estimulado (CE), Desnutrido Estimulado (DE), Controle Não Estimulado (CN) e Desnutrido Não Estimulado (DN) representados por mediana e intervalo interquartil

Número de sessões para atingir o critério - Reversão

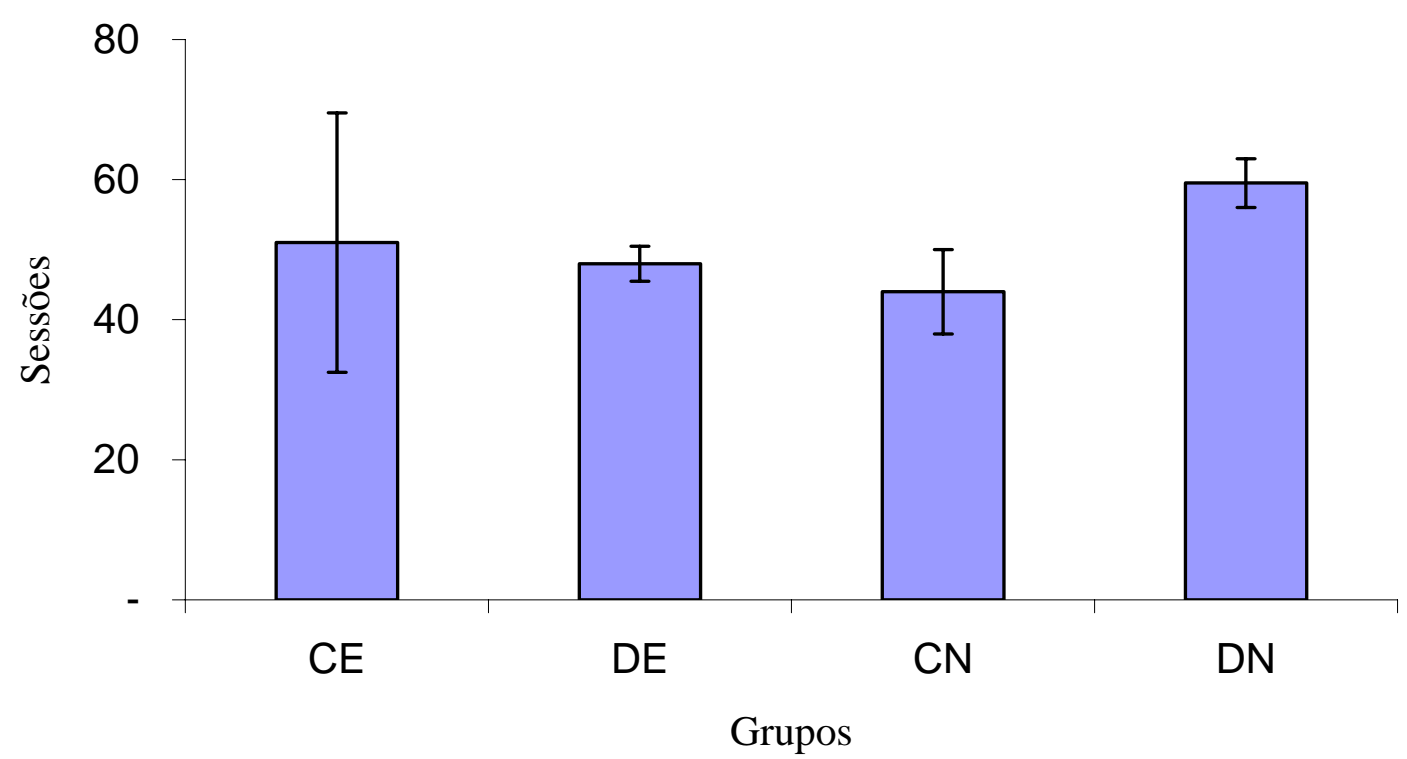

Figura 20. Número de sessões para atingir o critério na reversão da discriminação dos grupos Controle Não Estimulado (CN), Desnutrido Não Estimulado (DN) (n=6), Controle Estimulado (CE) $(n=6)$ e Desnutrido Estimulado (DE) $(n=6)$. As colunas representam os valores da mediana e as barras verticais o intevalo interquartil 


\section{Acertos}

Em relação ao número de acertos, a análise não mostrou diferenças nas sessões 1 a 15 (fase em que estavam todos os sujeitos em treino) tanto para efeito de dieta quanto para efeito de estimulação.

Apesar disso, a Figura 21 mostra que também houve um aumento gradual de acertos para todos os grupos na reversão ao longo das sessões (em torno de 50\% de acertos na sessão 1 em comparação com 80\% de acertos nas últimas sessões).

Nesta fase, as diferenças entre grupos ficam menos evidentes em comparação com a fase da discriminação. Também nessa fase, os animais DN precisaram de mais sessões para atingir o critério de acertos, assim como na discriminação.

\section{Acertos - Reversão}

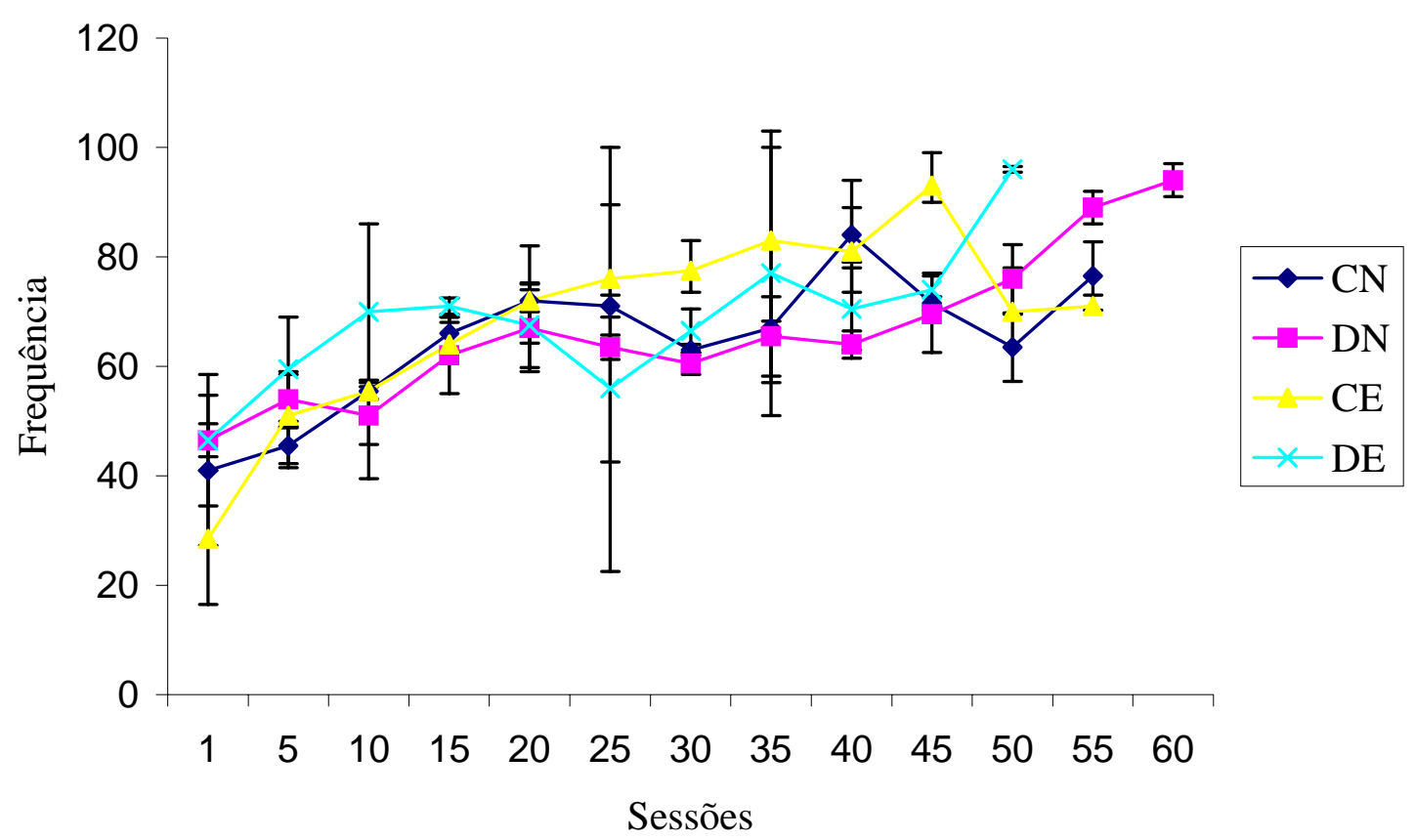

Figura 21. Freqüência de acertos em blocos de 5 sessões na reversão da discriminação dos grupos Controle Não Estimulado (CN), Desnutrido Não Estimulado (DN) (n=6), Controle Estimulado (CE) $(n=6)$ e Desnutrido Estimulado (DE) $(n=6)$. As linhas representam os valores da média e as barras verticais o Erro Padrão da Média (EPM) em blocos de 5 sessões 


\section{Duração da Tentativa}

A análise apontou um efeito significativo de dieta $(\mathrm{p}<0.05)$ nas sessões 1 e 5 com durações maiores da tentativa para os CE em relação aos DE na sessão 1 e durações maiores para os CN em comparação aos DN na sessão 5. Não houve efeito da estimulação.

A Figura 22 mostra oscilações menores de duração da tentativa nas sessões da reversão em comparação as da discriminação (Figura 18). Na reversão, as durações da tentativa foram pequenas e regulares desde a sessão 1, em torno de $5 \mathrm{~s}$, com exceção das sessões 50 e 55 para os $\mathrm{CN}$, em torno de $15 \mathrm{~s}$.

Duração da tentativa - Reversão

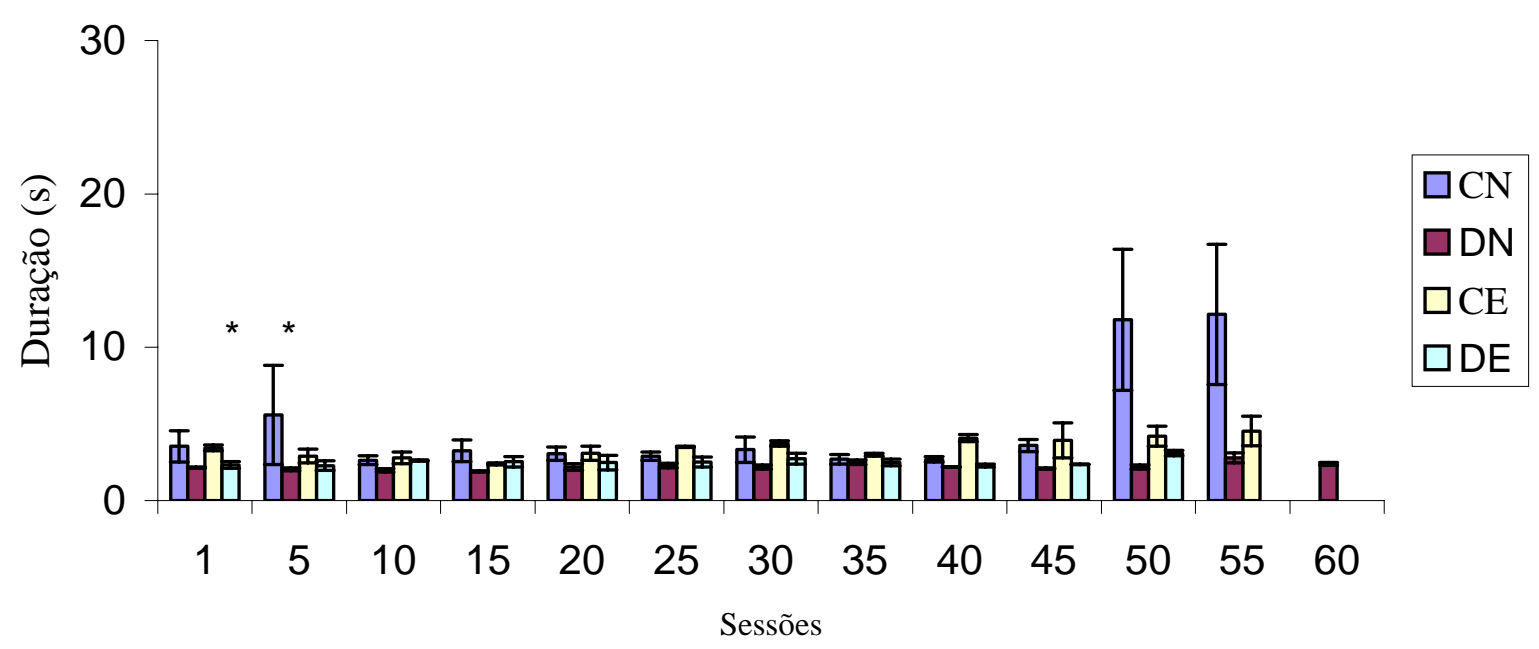

Figura 22. Duração da tentativa na reversão da discriminação dos grupos Controle Não Estimulado (CN) (n=6), Controle Estimulado(CE) (n=6), Desnutrido Estimulado (DE) (n=6) e Desnutrido Não Estimulado $(\mathrm{DN})(\mathrm{n}=6)$. As colunas representam os valores da média e as barras verticais o Erro Padrão da Média (EPM) em blocos de 5 sessões. O asterisco indica diferença significativa, * $\mathrm{p}<0,05$ 


\section{Intervalo Entre Tentativas}

A análise mostrou um efeito significativo de dieta $(\mathrm{p}<0,05)$, tendo os CE apresentado intervalos menores que os DE na sessão 1 (Figura 23). De modo geral os intervalos foram maiores para os controles (estimulados ou não) do que para os desnutridos (estimulados ou não).

Intervalo entre tentativas - Reversão

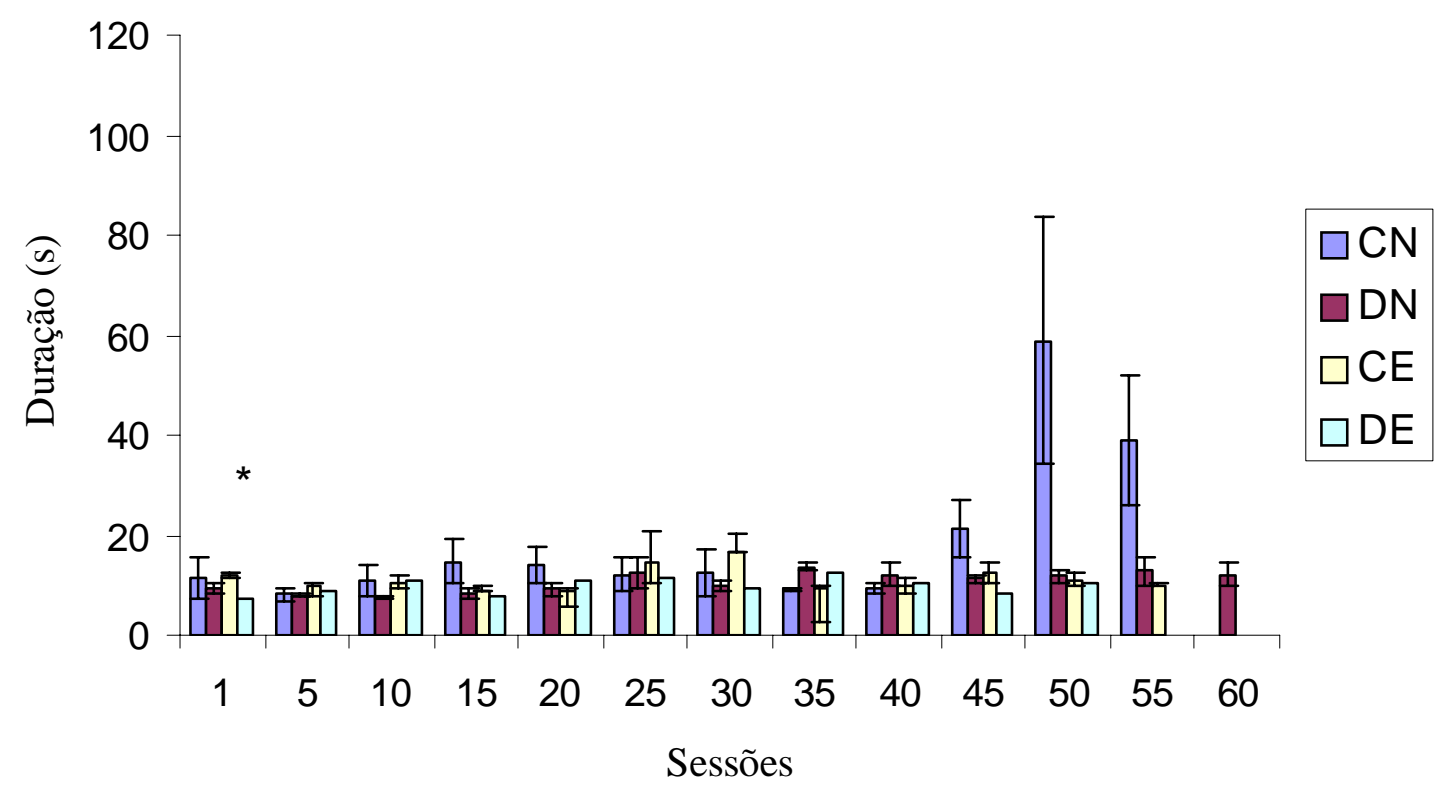

Figura 23. Intervalo Entre Tentativa durante a reversão dos grupos Controle Não Estimulado (CN) (n=6), Desnutrido Não Estimulado (DN) $(n=6)$, Controle Estimulado (CE) (n=6) e Desnutrido Estimulado (DE) $(\mathrm{n}=6)$. As colunas representam os valores da média e as barras verticais o Erro Padrão da Média (EPM) em blocos de 5 sessões. O asterisco indica diferença significativa entre grupos, ${ }^{*} \mathrm{p}<0,05$. 


\subsection{Discriminação Condicional}

Nesta fase não houve curva de aprendizagem para todos os grupos, mesmo com o treino prolongado de 70 sessões. Ao longo do treino, o número de acertos variou entre 40 a 55 \% de acertos para os vários grupos. Apesar disso, os intervalos de tempo (duração da tentativa e IET) foram curtos, assim como nas fases anteriores O quadro abaixo (Quadro3) mostra os dados da discriminação condicional em relação a número de acertos, erros, duração da tentativa e intervalo entre tentativa. Pode se observar também, que o número de acertos e erros permanece constante ao longo das sessões. Os espaços em branco, se referem a perda ou ao não armazenamento dos dados durante estas sessões. 
CN

\begin{tabular}{|c|c|c|c|c|c|c|c|c|c|c|c|c|c|c|c|}
\hline Sessões & 1 & 5 & 10 & 15 & 20 & 25 & 30 & 35 & 40 & 45 & 50 & 55 & 60 & 65 & 70 \\
\hline Acertos & 56,3 & 55,0 & 56,6 & 57,4 & 58,2 & 54,2 & 53,0 & 57,4 & 45,2 & 52,6 & 39,7 & 53,0 & 63,0 & 55,0 & 56,0 \\
\hline Erros & 65,0 & 65,0 & 63,4 & 62,6 & 61,7 & 65,8 & 67,0 & 62,8 & 74,7 & 67,4 & 70,2 & 67,0 & 57,0 & 65,0 & 64,0 \\
\hline DT & 4,0 & 5,2 & 8,4 & 3,9 & 2,8 & 2,4 & 2,3 & 2,2 & 6,6 & 3,4 & 3,2 & 2,6 & 2,4 & 2,1 & 2,6 \\
\hline IET & 15,4 & 21,4 & 21,8 & 21,6 & 18,2 & 13,6 & 10,9 & 14,0 & 19,5 & 19,2 & 16,3 & 19,2 & 13,8 & 10,6 & 19,3 \\
\hline
\end{tabular}

DN

\begin{tabular}{|c|c|c|c|c|c|c|c|c|c|c|c|c|c|c|c|}
\hline Sessões & 1 & 5 & 10 & 15 & 20 & 25 & 30 & 35 & 40 & 45 & 50 & 55 & 60 & 65 & 70 \\
\hline Acertos & 60,6 & 59,2 & 56,7 & 54,7 & 58,0 & 57,5 & 59,3 & 57,3 & 53,0 & 50,2 & 49,0 & 57,0 & 63,0 & & 60,0 \\
\hline Erros & 59,3 & 60,7 & 63,2 & 65,2 & 62,0 & 62,5 & 60,6 & 62,6 & 67,0 & 64,7 & 64,3 & 63,0 & 57,0 & & 60,0 \\
\hline DT & 2,2 & 2,1 & 2,2 & 2,3 & 2,4 & 2,4 & 2,1 & 2,1 & 5,0 & 3,0 & 2,8 & 2,4 & 2,6 & & 2,8 \\
\hline IET & 11,4 & 10,1 & 9,9 & 13,2 & 15,8 & 15,6 & 12,9 & 12,3 & 18,0 & 19,7 & 15,4 & 19,0 & 15,3 & & 23,9 \\
\hline
\end{tabular}

CE

\begin{tabular}{|l|l|l|l|l|l|l|l|l|l|l|l|l|l|l|l|}
\hline Sessões & 1 & 5 & 10 & 15 & 20 & 25 & 30 & 35 & 40 & 45 & 50 & 55 & 60 & 65 & 70 \\
\hline Acertos & 55,4 & 60,0 & 56,0 & 61,5 & 57,0 & 61,8 & 56,0 & 61,2 & 57,2 & 65,0 & 58,7 & 62,5 & 58,8 & 50,6 & 59,2 \\
\hline Erros & 64,6 & 60,0 & 64,0 & 58,5 & 63,0 & 58,2 & 64,0 & 58,7 & 62,7 & 62,5 & 61,2 & 57,5 & 61,2 & 59,4 & 60,8 \\
\hline DT & 44,2 & 3,4 & 2,9 & 2,4 & 2,1 & 2,2 & 2,1 & 2,7 & 6,1 & 3,6 & 3,4 & 2,4 & 2,8 & 2,1 & 2,1 \\
\hline IET & 20,3 & 15,1 & 12,9 & 15,3 & 12,4 & 10,2 & 14,2 & 17,0 & 22,4 & 18,4 & 16,4 & 13,4 & 19,6 & 11,7 & 9,9 \\
\hline
\end{tabular}

DE

\begin{tabular}{|c|c|c|c|c|c|c|c|c|c|c|c|c|c|c|c|}
\hline Sessões & 1 & 5 & 10 & 15 & 20 & 25 & 30 & 35 & 40 & 45 & 50 & 55 & 60 & 65 & 70 \\
\hline Acertos & 60,0 & 61,2 & 56,0 & 59,1 & 61,6 & 59,8 & 54,8 & 60,8 & 57,2 & 52,7 & 60,0 & 60,7 & 59,5 & 53,0 & \\
\hline Erros & 60,0 & 58,8 & 64,2 & 60,8 & 58,4 & 60,1 & 65,2 & 59,2 & 63,0 & 67,2 & 60,0 & 54,2 & 55,5 & 57,7 & \\
\hline DT & 2,4 & 11,5 & 2,9 & 1,9 & 1,9 & 2,0 & 1,9 & 1,9 & 4,3 & 2,6 & 1,9 & 1,8 & 1,9 & 1,9 & \\
\hline IET & 16,8 & 18,1 & 12,3 & 9,9 & 9,9 & 10,6 & 8,4 & 9,6 & 15,1 & 11,1 & 11,3 & 11,1 & 12,1 & 39,9 & \\
\hline
\end{tabular}

Quadro 3. Média do número de acertos, erros, duração da tentativa (DT) e Intervalo entre tentativas (IET) dos grupos Controle Não Estimulado (CN) $(n=6)$, Desnutrido Não Estimulado (DN) $(n=6)$, Controle Estimulado (CE) (n=6) e Desnutrido Estimulado (DE) ( $n=6)$ em blocos de 5 sessões durante a discriminação condicional. 


\subsection{DISCUSSÃO}

A análise dos pesos corporais das ratas-mãe durante o período da lactação mostrou uma redução de 30,9 \% dos pesos das ratas com dieta de 6 \% de proteína comparados com uma perda de 11,7 \% dos pesos das ratas controles (Figura 12). Esses resultados estão de acordo com dados anteriormente descritos no laboratório que também mostraram redução dos pesos das ratas que receberam dietas de 6\% de proteína (PEREIRA DA SILVA; DE OLIVEIRA, 2005; RIUL ET AL, 1999). Embora no dia 1 da lactação, os pesos das ratas desnutridas tenham sido maiores do que os pesos das controles (Figuras 3 e 12), com a introdução das dietas, as ratas desnutridas perderam mais peso do que as ratas controles no decorrer da lactação.

A perda de peso das ratas desnutridas também pode estar relacionada a um gasto energético maior decorrente da amamentação e do cuidado com os filhotes. Há dados de que as ratas-mãe desnutridas permanecem mais tempo amamentando e menos tempo fora do ninho do que as ratas-mãe controles (DE OLIVEIRA, 1985; PEREIRA DA SILVA; DE OLIVEIRA, 2005; RIUL et al., 1998).

A ingestão de dieta das ninhadas foi diferente praticamente em todo o período da lactação, sendo que, a ingestão das ninhadas desnutridas foi menor em comparação com a ingestão das controles (Figuras 8 e 15), o que também está de acordo com dados anteriores do laboratório (PEREIRA DA SILVA; DE OLIVEIRA, 2005; RIUL et al 1999). A ingestão de dietas foi principalmente das ratas-mãe nos primeiros dias da lactação, uma vez que os filhotes comiam no comedouro somente a partir do dia 14, quando ocorria a abertura dos olhos. Esta ingestão menor das ninhadas desnutridas também pode estar relacionada ao atraso da abertura dos olhos dos filhotes desnutridos que ocorria após 2 dias da abertura dos olhos dos filhotes controles (PELLEGRINI; NICOLA; DE OLIVEIRA, 2003). 
Visto que as ratas-mãe desnutridas receberam uma dieta com maior quantidade de carboidratos, mas com quantidades inadequadas de proteína, poderia ser esperado, que elas aumentassem a ingestão como uma maneira de compensar a deficiência protéica. Uma outra explicação para a menor ingestão das ratas-mãe desnutridas pode estar relacionada às diferenças do sabor e da textura das dietas oferecidas durante a lactação em comparação com as rações comerciais oferecidas durante a gestação. Na fase de lactação, as dietas foram oferecidas em pó, sendo que a dieta com 6\% de proteína era mais fina e leve que a dieta de $16 \%$ de proteína, desde que a quantidade de carboidrato foi aumentada em $10 \%$ em relação à dieta de 6\% de proteína, para manter níveis iguais de calorias nas duas dietas.

De acordo com Katz e Davies (1983), a quantidade de proteína é extremamente importante para garantir a quantidade de leite produzido. As ratas-mãe desnutridas poderiam, desta forma, estar oferecendo uma menor quantidade total de leite aos filhotes (desnutrição protéico-calórica), contribuindo também para a redução do peso dos filhotes desnutridos.

A desnutrição protéica das ratas-mãe durante a lactação afetou o peso corporal dos filhotes do experimento 1 (Figura 4) e do experimento 2 (Figura 13) de forma parecida. Estes dados também estão de acordo com dados anteriores obtidos no laboratório (RIUL ET AL, 1999, PEREIRA DA SILVA; DE OLIVEIRA, 2005). No dia 21 da lactação, a análise mostrou um efeito da estimulação em relação aos pesos dos animais, com filhotes controles estimulados pesando mais do que os filhotes controles não estimulados, como pode ser observado na Figura 13. A estimulação táctil eleva os níveis da ornitina descarboxilase (SHANBERG; FIELDS, 1987) aumentando a retenção de aminoácidos e os níveis do hormônio do crescimento. Estes processos bioquímicos decorrentes da estimulação táctil podem explicar as diferenças de peso entre animais estimulados e não estimulados.

O procedimento de recuperação nutricional para os desnutridos, não foi suficiente para igualar os pesos dos desnutridos em relação aos dos controles, indicando que a redução 
do crescimento dos animais desnutridos que receberam dietas de 6\% de proteína afetou o peso de forma irreversível (Figuras 6 e 14).

As alterações de pesos corporais citadas anteriormente, decorrentes da desnutrição, sem dúvida representam prejuízos para o organismo e a estimulação pode minimizar os efeitos ou prejuízos causados pela desnutrição.

A comparação do desempenho dos desnutridos e controles durante o treino da discriminação de luz ou som mostrou que não ocorreram diferenças entre grupos em relação aos índices de discriminação (Figura 9), que apesar de ser uma razão baseada em números de respostas, é uma maneira bastante habitual de análise em estudos de discriminação de estímulos. Entretanto, este tipo de análise representa apenas uma análise global da distribuição de respostas nas duas condições de estímulos.

De modo geral, ratos controles e desnutridos discriminaram os estímulos luz ou som (Figura 9) mostrando que o treino foi eficiente para estabelecer a discriminação tanto na aquisição como na reversão não havendo diferenças de desempenho dos controles e desnutridos, ao contrário dos estudos anteriormente citados (CASTRO; RUDY, 1989; CÉLEDON; SMART; DOBBING, 1982; TONKISS; STEPHENS, 1981; TONKISS et al., 1991).

Um aspecto nesse estudo que pode ter interferido na análise dos índices de discriminação de luz ou som e das respostas por segundo dos vários sujeitos mascarando possíveis diferenças entre controles e desnutridos pode estar relacionado com a escolha do esquema de Razão Variável (RV 12:1). Os esquemas de reforçamento intermitente de razão são baseados no número de respostas emitidas e geram freqüências altas e constantes no responder.

Os dados do presente estudo mostraram semelhanças no desempenho dos ratos diante de luz ou som, mesmo com a capacidade de percepção de luz mais limitada em ratos, 
principalmente em albinos, como comentam Prusky et al, (2002), o que não está de acordo com dados anteriormente descritos no laboratório (FELICIANO, DE OLIVEIRA, SOUZA, 2002) em que o número de erros dos ratos controles e desnutridos foi menor para o grupo com $S^{\mathrm{D}}$ som do que para os animais com $S^{\mathrm{D}}$ luz. Nesse procedimento após cada resposta de pressão à barra eram apresentados os estímulos discriminativos e a resposta diante do estímulo correto finalizava a tentativa. Uma nova tentativa iniciava com uma nova resposta de pressão à barra.

Em uma comparação de modalidades de estímulos (som, luz e odor) (NIGROSH et al, 1975) não encontraram diferenças do desempenho na discriminação. Entretanto, na reversão os ratos apresentaram melhor desempenho diante de odor em comparação com som e luz.

O estudo de O’Grady e Jennings (1974), comparou o desempenho diante de brilho e olfato. Após completar 10 reversões sucessivas, o grupo treinado com $\mathrm{S}^{\mathrm{D}}$ brilho, era revertido para estímulos olfatórios. Os sujeitos com $S^{\mathrm{D}}$ brilho reverteram mais rapidamente do que os treinados com o $\mathrm{S}^{\mathrm{D}}$ olfato, o que é contraditório com o estudo de Nigrosh, et al. (1975). Apesar da diferença de desempenho dos sujeitos em relação aos estímulos, todos os sujeitos quando reverteram para a situação original de treino apresentaram menos erros.

Na reversão da discriminação de som e luz, houve um desempenho semelhante entre desnutridos e controles, uma vez que não houve efeito de dieta e estímulo, o que não confirma em parte dados da literatura em procedimentos de reversão da discriminação em labirintos aquáticos (BARNES et al., 1966). Entretanto, Smart (1976) mostrou melhor desempenho para os desnutridos (SMART, 1976), enquanto no estudo de Cravens (1974) não houve diferença entre desnutridos e controles.

Desta forma, os dados da literatura de procedimentos de reversão da discriminação em desnutridos são conflitantes. Os estudos que se preocuparam em analisar os efeitos da desnutrição sobre discriminação e reversão mostraram muitas variações de procedimentos. Em todos os estudos de reversão acima citados foram realizadas poucas sessões ou tentativas 
de teste o que dificulta a comparação com estudos com um número maior de sessões de treino. Neste estudo, o procedimento de reversão somente foi iniciado após 15 sessões de treino da discriminação, quando o desempenho estava estável.

Mackintosh et al (1968) levanta a questão de que ratos treinados em um procedimento de reversão da discriminação visual ou espacial aprendem as reversões seriais posteriores mais rapidamente do que as reversões anteriores e que quando a reversão é proposta no mesmo dia o desempenho é melhor do que se a reversão é proposta em dias sucessivos. Os autores usaram diferentes procedimentos na aquisição e na reversão, salientando que as últimas reversões foram aprendidas com uma média de erros menor do que nas primeiras reversões. No presente estudo foi solicitado apenas uma única reversão, ou seja, a reversão dos estímulos discriminativos luz ou som logo após a aquisição da discriminação.

Na maioria dos estudos sobre efeitos da desnutrição no comportamento há uma dificuldade de separar as variáveis que afetam a capacidade de aprendizagem, daquelas que alteram o desempenho nas diferentes situações de testes (BARRET; FRANK, 1987; LEVITSKY, 1979). Alguns estudos com animais desnutridos mostraram indícios de maior motivação para estímulos de natureza alimentar (comida ou água) evidenciada pela maior ingestão, maior armazenamento ou derramamento de alimento (BARNES et al., 1968).

Os dados comportamentais do experimento de discriminação simples de luz ou som mostraram pouquíssimas diferenças do fator dieta, indicando que o fator motivacional do animal desnutrido requer uma melhor análise. Um aspecto que deve ser salientado é que os estudos que encontraram efeitos no comportamento alimentar, realizaram testes de curta duração. No presente estudo, o número maior de sessões de treino (15 sessões na discriminação) pode ter produzido um efeito adaptativo à situação de privação. Visto que os dados da literatura se baseiam em privações agudas e testes comportamentais com poucas sessões ou tentativas de treino, o desempenho nas fases de discriminação e reversão de luz ou 
som pode ter sido controlado mais pelo procedimento e pelas contingências em cada fase do que necessariamente um efeito geral de variáveis motivacionais.

A implantação do procedimento do Experimento 2 para estudar discriminações em ratos foi uma tentativa de melhor controle das variáveis que podem afetar o desempenho durante a situação de treino. Nesse procedimento, ficou reduzido o efeito de esquemas que geram desempenhos de altas freqüências, desde que a apresentação dos estímulos foi controlada pelo próprio rato ao pressionar a barra que produzia o inicio da tentativa.

Os dados do número de sessões para atingir o critério de acertos na discriminação Quadro 1 (ANEXO E) mostraram um melhor desempenho dos controles em relação aos desnutridos, confirmando que quando são realizados procedimentos mais sutis de avaliação de processos de aprendizagem as diferenças de desempenho entre controles e desnutridos são observadas. Os dados também mostraram que foram necessárias mais sessões de treino para os não estimulados do que para os estimulados, conforme descrito no Quadro 1 (ANEXO E).

Efeitos da estimulação são consistentes em procedimentos com estímulos aversivos dolorosos como na aprendizagem de esquiva (DE OLIVEIRA; ALMEIDA, 1985; LIMA; DE OLIVEIRA \& ALMEIDA, 1999); limiar de resposta ao choque (ROCINHOLI et al., 1997), bem como em teste de estímulos aversivos brandos como o Teste Claro Escuro (SANTUCCI et al., 1994).

Na reversão da discriminação $\left(S^{\mathrm{D}}\right.$ triângulo), embora a maioria dos sujeitos de cada condição tenha atingido o critério de acertos (Figura 21), com exceção dos desnutridos não estimulados, os dados mostraram que foram necessárias um número maior de sessões para atingir o critério nos vários grupos em comparação com os dados da discriminação (Figura 17), mostrando ser a reversão uma tarefa mais difícil do que a discriminação.

De modo geral, o procedimento se mostrou útil para avaliar mudanças de comportamento diante da apresentação de diferentes estímulos (linha ou triângulo) uma vez 
que o desempenho mostrou freqüências altas de acertos. Entretanto, foi necessário um número relativamente alto de sessões para estabelecer a discriminação usando linha e triângulo como estímulos, mesmo para os animais controles (em torno de 20 sessões). Uma alternativa para facilitar a aquisição de repertórios de discriminação, seria o uso do procedimento de fading in, descrito por Terrace (1963), que está em andamento no laboratório. Resultados recentes com esse procedimento apontam para um menor número de sessões necessárias para estabelecer a discriminação com os sujeitos do grupo fading em comparação com os do grupo não fading, com estímulos linha e triângulo (HOELZ et al, 2006).

A comparação dos dados de acertos na discriminação condicional (Quadro 3) permite afirmar que não houve aprendizagem nesta fase, o que confirma a dificuldade do procedimento de discriminação condicional com ratos (IVERSEN, 1993, 1997). A idéia inicial era investigar se após o treino de discriminações condicionais os ratos eram capazes de formar relações entre estímulos não diretamente treinadas, como por exemplo, verificar através de sondas a propriedade de simetria. Por conta da dificuldade de estabelecer discriminações condicionais nesse procedimento e de não ter havido aprendizagem nessa fase, não foi realizado o teste da simetria. De acordo com Sidman (1994) só é possível avaliar se o desempenho de um sujeito em uma discriminação condicional envolve propriedades de equivalência de estímulos analisando o número de acertos nas tentativas de teste, uma vez que é através dos testes que se torna possível a intercambialidade ou capacidade de substituição da função dos estímulos.

Nesse procedimento, os estímulos condicionais (som constante ou interrompido) eram alternados a cada bloco de 30 tentativas e produzidos através da resposta de pressão à barra. Os estímulos condicionais permaneciam acionados juntamente com os estímulos discriminativos (linha ou triângulo) até a emissão da resposta correta. Algumas explicações 
podem ser dadas para analisar a dificuldade de obtenção de aprendizagem nessa fase, mesmo com um extenso treino de 70 sessões (Quadro 3).

Uma delas é que os ratos pressionam a barra e após um giro de 90 graus aparentemente "não prestavam atenção” aos estímulos e emitiam a resposta de nose poken nos túneis sem olhar para os estímulos, o que gerou durações e intervalos entre tentativas curtos para todos os grupos. Entretanto, pequenas durações da tentativa e intervalos entre tentativa também podem estar relacionados a fatores motivaçionais, especialmente para os desnutridos (BARNES et al, 1968).

O fato da apresentação dos estímulos linha e triângulo após as pressões à barra ter sido feita acima dos túneis, requisitou que os animais levantassem a cabeça para observar os estímulos que estavam sendo apresentados. Os estímulos linha e triângulo que foram apresentados sobre os túneis estavam a 7,0 cm de altura enquanto o local do reforço ficava a 3,0 cm de altura em relação ao piso da caixa, o que pode ter gerado uma desorganização do repertório comportamental.

Além disso, as respostas dos animais antes de iniciar a discriminação condicional estavam sob o controle do estímulo triângulo apresentado como $S^{\mathrm{D}}$ na fase de reversão da discriminação. Isto pode ter gerado uma desorganização do repertório de respostas dos vários sujeitos no início do treino da condicional.

Desta forma, podem ter ocorrido várias relações de controle do responder que podem ter sido mantidas pelas contingências de reforçamento, dificultando o estabelecimento da discriminação condicional, conforme comentam Dube e McIlvane (1996).

Uma alternativa possível para tentar estabelecer a discriminação condicional em ratos seria realizar sessões de treino apresentando somente um dos estímulos condicionais (como Som Constante) pareado com o $S^{\mathrm{D}}$ linha até a obtenção do critério de acertos. Posteriormente 
apresentar o estímulo condicional Som Interrompido pareado com o $S^{\mathrm{D}}$ triângulo até a obtenção do critério de acertos, e somente depois intercalar os estímulos condicionais. Nesse estudo alternar a apresentação dos estímulos condicionais em 4 blocos de 30 tentativas mostrou-se ser uma tarefa muito difícil para os ratos, independente das condições de dieta e de estimulação.

Os dados de Iversen (1997) mostraram que os desempenhos na discriminação condicional podem ser estabelecidos com ratos apenas após 60 sessões com o procedimento de matching to sample de identidade. Nesse procedimento, foi utilizado um emparelhamento arbitrário (modelo som constante ou interrompido pareado com $\mathrm{S}^{\mathrm{D}}$ linha ou triângulo) e houve dificuldade de estabelecer a discriminação condicional mesmo com 70 sessões de treino.

Levando em conta o desempenho irregular e uma freqüência de acertos entre 50 e 60\% na discriminação condicional, não foram introduzidas as sondas de simetria. Mesmo não estabelecendo a discriminação condicional, o equipamento e o programa desenvolvidos para este estudo permitem a inclusão de diversos procedimentos como alternativas para estudar processos de aprendizagem complexa em ratos. 
CONCLUSÃO 


\subsection{CONCLUSÃO}

- O modelo de desnutrição empregado produziu perdas de pesos corporais marcantes, tanto nas ratas-mãe quanto nos filhotes alimentados com dieta de 6\% de proteína.

- Os desnutridos aprenderam tanto quanto os controles a discriminação de luz ou som e a reversão da discriminação (experimento 1).

- No procedimento de discriminação de linha e triângulo (experimento 2), houve um efeito de dieta, sendo necessárias mais sessões de treino para os desnutridos atingirem o critério. Houve uma tendência de melhor desempenho dos estimulados em relação ao não estimulados.

- No procedimento de reversão da discriminação, não houve diferença significativa no número de sessões para atingir o critério entre os grupos, entretanto houve uma prevalência de pior desempenho para os animais desnutridos e para os animais não estimulados.

- Não houve aprendizagem na discriminação condicional sendo necessário outros procedimentos para estudar aprendizagem complexa em ratos, entretanto, o equipamento desenvolvido para este estudo permite fazer possíveis adaptações para os estudos de aprendizagem complexa. 
ANEXO 


\subsection{ANEXO}

ANEXO A. Composição e proporção (\%) dos nutrientes utilizados na preparação das dietas controle (16\% de proteína) e deficiente (6\% de proteína) durante a lactação (1-21 dias de idade) e pós-lactação (22 a 35 dias de idade) dos grupos controles (C) e desnutridos (D)

\begin{tabular}{lcc}
\hline Componente & $16 \%$ & $6 \%$ \\
\hline Proteína & 16,0 & 6,0 \\
Metionina & 0,032 & 0,012 \\
Carboidrato & 69,768 & 79,788 \\
Gordura & 8,0 & 8,0 \\
Mistura salina & 5,0 & 5,0 \\
Mistura vitamínica & 1,0 & 1,0 \\
Colina & 0,2 & 0,2 \\
\hline
\end{tabular}

\section{Fornecedores:}

Proteína = caseína $($ SKF, Alemanha $)$

L-metionina (Dyets, EUA)

Gordura = óleo de milho $\left(\right.$ Mazola ${ }^{\circledR}$ Refinarias de Milho, Brasil $)$

Mistura salina (Rhoster Indústria e Comércio Ltda., Brasil)

Mistura vitamínica (Rhoster Indústria e Comércio Ltda., Brasil)

Colina (Rhoster Indústria e Comércio Ltda., Brasil)

Carboidrato $=$ amido de milho (Maisena ${ }^{\circledR}$ Refinarias de Milho, Brasil) 
ANEXO B. Mistura Salina: composição básica do suplemento mineral para animais de laboratório - AIN-93. Níveis de garantia por quilograma do produto AIN-93G

\begin{tabular}{llll}
\hline Componente & Quantidade & Componente & Quantidade \\
\hline Boro & $14,26 \mathrm{mg}$ & Magnésio & $14,48 \mathrm{~g}$ \\
Cálcio & $142,94 \mathrm{~g}$ & Manganês & $300 \mathrm{mg}$ \\
Cloro & $44,90 \mathrm{~g}$ & Molibdênio & $4,32 \mathrm{mg}$ \\
Cobre & $172,41 \mathrm{mg}$ & Níquel & $14,31 \mathrm{mg}$ \\
Cromo & $28,65 \mathrm{mg}$ & Potássio & $102,87 \mathrm{~g}$ \\
Enxofre & $8,60 \mathrm{~g}$ & Selênio & $4,28 \mathrm{mg}$ \\
Ferro & $1000 \mathrm{mg}$ & Silício & $143,26 \mathrm{mg}$ \\
Flúor & $28,72 \mathrm{mg}$ & Sódio & $29,38 \mathrm{~g}$ \\
Fósforo & $44,61 \mathrm{~g}$ & Vanádio & $2,87 \mathrm{mg}$ \\
Iodo & $5,93 \mathrm{mg}$ & Zinco & $860 \mathrm{mg}$ \\
Lítio & $2,85 \mathrm{mg}$ & & \\
\hline
\end{tabular}


ANEXO C. Mistura vitamínica e composição básica do suplemento vitamínico para animais de laboratório - AIN-93 (Instituto Americano de Nutrição). Níveis de garantia por quilograma do produto AIN-93

\begin{tabular}{llll}
\hline Componente & Quantidade & Componente & Quantidade \\
\hline Ácido fólico & $200 \mathrm{mg}$ & Vitamina A & $400.000 \mathrm{UI}$ \\
Acido nicotínico & $3000 \mathrm{mg}$ & Vitamina B12 & $2500 \mathrm{mcg}$ \\
Biotina & $20.000 \mathrm{mcg}$ & Vitamina D3 & $100.000 \mathrm{UI}$ \\
Pantotenato de cálcio & $1600 \mathrm{mg}$ & Vitamina E & $7500 \mathrm{UI}$ \\
Piridoxina & $700 \mathrm{mg}$ & Vitamina K1 & $75000 \mathrm{UI}$ \\
Riboflavina & $600 \mathrm{mg}$ & Sacarose & $97.465 \%$ \\
Tiamina & $600 \mathrm{mg}$ & & \\
\hline
\end{tabular}


ANEXO D . Composição da dieta comercial de laboratório, Nuvilab CR1 (segundo informações do fabricante) e níveis de garantia (\%)

\begin{tabular}{l} 
Componentes \\
\hline Carbonato de cálcio \\
Farelo de milho \\
Farelo de soja \\
Fosfato bicálcico \\
Cloreto de sódio \\
Premix mineral vitamínico \\
Aminoácido \\
$\quad$ Suplementação / $\mathrm{kg}$
\end{tabular}

\begin{tabular}{llll}
\multicolumn{3}{c}{ Suplementação $/ \mathrm{kg}$} \\
\hline Componente & Quantidade & Componente & Quantidade \\
\hline Vitamina A & $12.000 \mathrm{UI}$ & Colina & $600,00 \mathrm{mg}$ \\
Vitamina D3 & $1.800 \mathrm{UI}$ & Metionina & $300 \mathrm{mg}$ \\
Vitamina E & $30,00 \mathrm{mg}$ & Ferro & $50,00 \mathrm{mg}$ \\
Vitamina K3 & $3,00 \mathrm{mg}$ & Zinco & $60,00 \mathrm{mg}$ \\
Vitamina B1 & $5,00 \mathrm{mg}$ & Cobre & $10,00 \mathrm{mg}$ \\
Vitamina B2 & $6,00 \mathrm{mg}$ & Iodo & $2,00 \mathrm{mg}$ \\
Vitamina B6 & $7,00 \mathrm{mg}$ & Manganês & $60,00 \mathrm{mg}$ \\
Vitamina B12 & $20 \mathrm{mcg}$ & Selênio & $0,05 \mathrm{mg}$ \\
Niacina & $60,00 \mathrm{mg}$ & Cobalto & $1,50 \mathrm{mg}$ \\
Ácido pantotênico & $20,00 \mathrm{mg}$ & DL-metionina & $300,00 \mathrm{mg}$ \\
Ácido fólico & $1,00 \mathrm{mg}$ & Lisina & $100,00 \mathrm{mg}$ \\
Biotina & $0,05 \mathrm{mg}$ & & \\
\hline
\end{tabular}

Níveis de Garantia (\%):

Umidade (máximo) - 12.50; proteína bruta (mínimo) - 22.00; extrato etéreo (mínimo) - 4.00; matéria mineral (máximo) - 10.00; matéria fibrosa (máximo) - 8.00; cálcio (máximo) - 1.40; fósforo (mínimo) - 0.80 


\section{ANEXO E}

\begin{tabular}{|c|c|c|c|}
\hline$\overline{C E}$ & $\mathbf{D E}$ & $\mathrm{CN}$ & DN \\
\hline ões & & 年 & 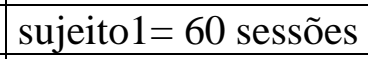 \\
\hline sujeito $2=23$ sessões & sujeito $2=43$ sessões & sujeito $2=23$ sessões & sujeito $2=50$ sessões \\
\hline Sujeito $3=17$ sessões & Sujeito $3=48 \mathrm{~s}$ & Sujeito $3=18 \mathrm{~s}$ & Sujeito $3=43$ \\
\hline Sujeito 4=60 sessões & Sujeito $4=23$ sessões & Sujeito 4=21 sessões & Sujeito $4=60$ \\
\hline Sujeito $5=17$ sessões & Sujeito $5=14$ sessões & $5=44$ & $05=60$ \\
\hline Sujeito 6=19 sessões & Suje & $\begin{array}{l}\text { Sujeito } 6=24 \text { sessões } \\
\text { Sujeito } 7=25 \text { sessões }\end{array}$ & Sujeito 6=60 sessões \\
\hline $\begin{array}{l}\text { MÉDIANA= 20,5 } \\
\text { INTERQUARTIL= 3,0 }\end{array}$ & $\begin{array}{l}\text { MÉDIANA= 33,0 } \\
\text { INTERQUARTIL= 16,2 }\end{array}$ & $\begin{array}{l}\text { MEDIANA= 23,5 } \\
\text { INTERQUARTIL= 2,0 }\end{array}$ & $\begin{array}{l}\text { MÉDIANA=60,0 } \\
\text { INTERQUARTIL= 7,5 }\end{array}$ \\
\hline
\end{tabular}

\begin{tabular}{|l|l|l|l|}
\hline CE & DE & CN & DN \\
\hline sujeito1=60 sessões & sujeito1=47 sessões & sujeito1=60 sessões & sujeito1=60 sessões \\
\hline sujeito 2=27 sessões & sujeito 2=60 sessões & sujeito 2=59 sessões & sujeito 2=59 sessões \\
\hline Sujeito 3=53 sessões & Sujeito 3=45 sessões & Sujeito 3=38 sessões & Sujeito 3=26 sessões \\
\hline Sujeito 4=49 sessões & Sujeito 4=49 sessões & Sujeito 4=22 sessões & Sujeito 4=60 sessões \\
\hline Sujeito 5=60 sessões & Sujeito 5=50 sessões & Sujeito 5=44 sessões & Sujeito 5=60 sessões \\
\hline Sujeito 6=19 sessões & Sujeito 6=30 sessões & & Sujeito 6=55 sessões \\
\hline $\begin{array}{l}\text { MEDIANA=51,O } \\
\text { INTERQUARTIL= 18,5 }\end{array}$ & $\begin{array}{l}\text { MEDIANA= 48,O } \\
\text { INTERQUARTIL=2,5 }\end{array}$ & $\begin{array}{l}\text { MEDIANA= 44,O } \\
\text { INTERQUARTIL=6,0 }\end{array}$ & $\begin{array}{l}\text { MEDIANA= 59,5 } \\
\text { INTERQUARTIL= 3,5 }\end{array}$ \\
\hline
\end{tabular}

Quadro 1. Número de sessões para atingir o critério de acertos (experimento 2) dos sujeitos (1, 2, 3, 4, 5 e 6) dos grupos Controle Estimulado (CE), Desnutrido Estimulado (DE), Controle Não Estimulados(CN) e Desnutrido Não Estimulado (DN) durante a discriminação (parte superior) e reversão da discriminação (parte inferior) 


\subsection{REFERÊNCIAS}

ALMEIDA, S.S.; GARCIA, R. A.; DE OLIVEIRA, L. M. Effects of early malnutrition and repeated testing upon locomotor and exploratory behaviors in the elevated plus-maze. Physiology \& Behavior, Oxford, v. 54, p. 749-752, 1993.

ALMEIDA, S. S.; DE OLIVEIRA L. M. Acquisition and extinction of jumping two-shuttle box and bar press avoidance responses in malnourished rats: effects as shock. Brazilian Journal of Medical and Biological Research, Ribeirão Preto, v.27, p. 2443-2452, 1994.

BARNES, R. H.; CUNNOLD, S. R.; ZIMMERMAN, R. R.; SIMMONS, H.; MACLEOD, R. B.; KROOK, L. Influence of nutritional deprivations early in life on learning behavior of rats measured by performance in a water maze. The Journal of Nutrition, Philadelphia, v. 89, p. 399-410, 1966.

BARNES, R. H.; NEELY, C. S.; KWONG, E.; LABADAN, B. A.; FRAÑKOVA, S. Postnatal nutritional deprivations as determinants of adult rat behavior toward food, its consumption and utilization. The Journal of Nutrition, Philadelphia, v. 96, p. 467- 476, 1968.

BARRET, D. E.; FRANK D. A. The effects of undernutrition on children's behavior. In: Food and Nutrition in History and Anthropology, Montreux, Gordon and breach Science Publishers S. A, 1987. p. 107-193.

BARROS, R. S.; GALVÃO, O. F.; MCILVANE, W. J. Generalized identity matching to sample in Cebbus apela. The Psychological Record, Ohio, v. 52, p. 441-460, 2002.

BRIONI, J. D.; ORSINGHER, O. A. Operant Behavior and reactivity to the anticonflict effect of diazepam in perinatally undernourished rats. Physiology \& Behavior, Oxford, v. 44, p.193-198, 1988.

CARTER, D. E.; ECKERMAN, D. A. Symbolic matching by pigeons: Rate of learning complex discrimination predicted from sample discrimination. Science, Washington, v. 187, p. 662-664, 1975.

CASTRO, C. A.; RUDY, J. W. Early-life malnutrition impairs the performance of both young and adults on visual discrimination learning tasks. Developmental Psychobiology, New York, v. 22, p. 15-28, 1989. 
CATÂNIA, A.C. Aprendizagem: comportamento, linguagem e cognição. Tradução: DEISY, D.G.S. et al.; 4. ed. Porto Alegre: Artes Médicas, Sul, 1999, 467p.

CELEDÓN, J. M.; SANTANDER, M.; COLOMBO, M. Long-term effects of early undernutrition and environmental stimulation on learning performance of adults rats. The Journal of Nutrition, Philadelphia, v. 109, n. 11, p. 1880-1886, 1979.

CELEDÓN, J. M.; SMART, J. L .; DOBBING. J. Effects of level of motivation on visual discrimination transfer of learning, and long-term memory in previously undernourished and control rats. Nutrition and Behavior, v.1, p. 89-97, 1982.

CHAVES, A.; MARTINEZ, C.; YASCHINE, T. Nutrition behavioral, development and mother-child interaction in young rural children. Federation Proceedings, Washington, v. 34, p.1583-1586, 1975.

CRAVENS, R. W. Effects of maternal undernutrition on offspring behavior: incentive value of a food reward and ability to escape from water. Developmental Psychobiology, New York, v. 7, p. 61-69, 1974.

CRNIC, L. S. Models of infantile malnutrition in rats: Effects on maternal behavior. Developmental Psychobiology, New York, v.13, p. 615-628, 1980.

CRNIC, L. S. Effects of nutrition and environment on brain biochemistry and behavior. Developmental Psychobiology, New York, v. 16, n.2, p. 129-145, 1983

CUMMING, W. W.; BERRYMAN, R. The complex discriminated operant: studies of matching-to-sample and related problems. In: Stimulus generalization. Stanford: University Press, 1965. p. 284-330.

DAL BELLO, A. C.; DE OLIVEIRA, L. M. Desnutrição e estresse na gestação: medidas comportamentais das mães dos filhotes durante a lactação. No prelo. Temas em Psicologia, São Paulo, 2004.

DE CAMPOS, P. R. Estudo das interações entre desnutrição e estimulação ambiental sobre o comportamento do rato. 2006. Monografia (Conclusão de curso) Faculdade de Filosofia, Ciências e Letras de Ribeirão Preto, Universidade de São Paulo, Ribeirão Preto, 2006.

DE OLIVEIRA, L. M. Malnutrition and environmental interaction effects upon animal behavior. Revista Chilena de Nutrición, Santiago, v. 13, p. 99-106, 1985. 
DE OLIVEIRA, L. M.; ALMEIDA, S. S. Effects of malnutrition and environment on the acquisition and the extinction of avoidance behavior in rats. Physiology \& Behavior, Oxford, v. 34, p. 141-145, 1985.

DENENBERG, V. H. The effects of early experience. In: The behaviour of domestic animals. London, 1969, p. 95-130.

DE ROSE, J. C.; SOUZA, D. G.; ROSSITO, A. L.; DE ROSE, T. M. S. Aquisição de leitura após história de fracasso escolar: Equivalência de Estímulos e Generalização. Psicologia: Teoria e Pesquisa, Brasília, v. 5, n.33, p. 325-346, 1989.

DEVANY, J. M.; HAYES, S. C; NELSON, R. Equivalence class formation in language-able and language-disable children. The Journal of Experimental Analysis of Behavior, Bloomington, v. 46, p. 243-257, 1986.

DOBBING, J. In: Early nutrition and later achievement. London: Academic Press, 1987.

DUBE, W. V.; MCILVANE, W. J. Some implications of a stimulus control topography analysis for emergent stimulus classes. In: Stimulus class formation in humans and animals. North Holland, 1996, p. 197-218.

FELICIANO, E. A.O.; SOUSA, D. D. G.; DE OLIVEIRA, L. M. Medidas de aprendizagem de discriminações complexas em ratos controles e desnutridos com apresentação de estímulos sobrepostos no procedimento de comparação com o modelo. Dissertação (Mestrado) Faculdade de Filosofia, Ciências e Letras de Ribeirão Preto, Universidade de São Paulo, Ribeirão Preto, 2002.

FERNÁNDEZ-TERUEL.; A; ESCORIHUELA, R. M.; CASTELLANO, B.; GONZÁLEZ, B.; TOBEÑA, A. Neonatal handling and environmental enrichment effects on emotionality, novelty reward seeking, and ge-related cognitive and hippocampal impairments. Behavioral Genetics, New York, v. 27, p. 513-526, 1997.

FIELD, T. Massage therapy effects. The American Psychologist, Washington, v. 53, p. 1270-1281, 1998.

FIELD, T.; SHANBERG, S. M.; SCAFIDI, F.; BAUER, C. R; VEGA-LAHR, N.; GARCIA, R., NYSTROM, J.; KUHN, C. Tactile kinesthetic stimulation effects on preterm neonates. Pediatrics, Springfield, v. 77, p. 654-658, 1986. 
FOOD AGRICULTURE E ORGANIZATION (FAO). World hunger increasing. 2006. Disponível em: http:// w.w.w. fao.org. Acesso em: 03 dez. 2006.

FRAÑKOVÁ, S. Nutritional and psychological factors in development of spontaneous behavior in the rat. In: Malnutrition, learning and behavior. Scrimshaw, N. S. e Gordon, J. E. (Ed): M.I.T. Cambridge Press, 1968, p. 312-327.

FRAÑKOVÁ, S.; BARNES, R. H. Effects of malnutrition in early life on avoidance conditioning and behavior of adult rats. Nutrition, Califórnia, v. 96, p.485-493, 1968.

FUNDO DAS NAÇÕES UNIDAS PARA A INFÂNCIA (UNICEF). Situação da Infância Brasileira. 2006. Disponível em: http://www.unicef.org.br Acesso em: 03 dez.2006.

GALVÃO, O. F.; BARROS, R.S.; ROCHA, A.C.; MENDONÇA, M.B.; GOULART. P. R. K Escola experimental de primatas. Estudos de Psicologia, Natal. v. 7, n. 2. p. 361-370, 2002.

GRANTHAM- MCGREGOR, S. A review of studies of the effect of severe malnutrition on mental development. Journal of Nutrition, Philadelphia, v. 125, p. 2233-2238, 1995.

HOELZ, G.T.; FELICIANO, E. A. O; DE OLIVEIRA, L.M. Efeitos da desnutrição protéica em procedimento de fading-in em ratos. In: Reunião anual da Sociedade Brasileira de Psicologia, XXXVI; 2006, Salvador. Resumos...Salvador: SBP, 2006.

IVERSEN, I. H. Acquisition of matching-to-sample performance in rats using visual stimuli on nose keys. Journal of the Experimental Analysis of Behavior, Bloomington, v.59, p. 471-482, 1993.

IVERSEN, I. H.. Matching-to-sample performance in rats: A case of mistaken identity? Journal of the Experimental Analysis of Behavior, Bloomington, v. 68, p.27-45, 1997.

KASTAK, C. R..; SHUSTERMAN, R. J.; KASTAK, D. Equivalence classification by California sea lions using class-specific reinforces. Journal of the Experimental Analysis of Behavior, Bloomington, v. 76, p. 131-158, 2001.

KATZ, H. B.; DAVIES, C. A. The separated and combined effects of early undernutrition and environmental complex at different ages on cerebral measures in rats. Developmental Psychobiology, New York, v. 16. n.1, p. 47-58, 1983.

KIMBLE, G. A. Conditioning and learning. Hilgard; Marquis, New York, v. 1, 1961, 367 p. 
LASHEY, K.S. Conditional discrimination in rats. Journal of Psychology, Washington, v. 6.p.311-324, 1938.

LEVITSKY, D. A. Malnutrition and the hunger to learn. In: Malnutrition, Environment, and Behavior. Ithaca: Cornell University Press, 1979. p.161-179.

LEVITSKY, D. A.; BARNES, R. H. Nutritional and environmental interactions in the behavioral development of the rat: long term effects. Science, Washington, v. 176, p. 68-71, 1972.

LEVITSKY, D. A.; STRUPP, B. J. Malnutrition and the brain: changing concepts, changing concerns. The Journal of Nutrition, Philadelphia, v. 125, p. 2212 - 2220, 1995.

LIMA, J. G.; DE OLIVEIRA, L. M.; ALMEIDA, S. S. Effects of early concurrent protein malnutrition and environmental stimulation on the central nervous system and behavior. Nutritional Neuroscience, London, v. 1, p. 439-448, 1999.

MACKINTOSH, N. J.; MCGONIGLE, B.; HOLGATE, V.; VANDERVER, V. Factors underlying improvement in serial reversal learning. Canadian Journal of Psychology, Toronto, v. 22, 85 - 95, 1968.

MANABE, K.; KAWASHIMA, T.; STADDON, J. E. R. Differential vocalization in budgerigars: towards an experimental analysis of naming. Journal of the Experimental Analysis of Behavior, Bloomington, v. 63, p. 111-126, 1995.

MCINTIRE, K. D.; CLEARY, J.; THOMPSON, T. Conditional relation symmetry and transitivity. Journal of the experimental analysis of behavior, v. 47. p.279-285. 1987.

MEANEY, M. J.; AITKEN, D. H.; BHATNAGAR, S.; VAN BERKEL, C. H.; SAPOLSKY, R. M. Effects of neonatal handling on age-related impairments associed with hippocampus. Science, Washington, v. 239, p. 766-768, 1988.

MORENO, A. M.; ROCCA. J. Z .; DE OLIVEIRA, L. M.; SOUZA, D. G. Discriminações condicionais entre estímulos visuais e testes de simetria em melíponas. Revista Brasileira de Análise do Comportamento, Brasília, v.1, n.2, p. 207-229, 2005.

MORGANE, P.J.; MILLER, M.; KEMPER, T.; STERN, W.; HALL, R; BRONZINO, J.; HAWRYLEWICZ., E.; RENISCH, O. The effects of protein malnutrition and the developing 
central nervous system in the rats. Neuroscience and Biohevioral Reviews, New York, v.2, p.137-230, 1978.

MORGANE, P.J.; AUSTIN LAFRANCE, R. J.; BRONZINO, J. D.; TONKISS, J.; DÍAZCINTRA, S.; CINTRA, L.; KEMPER, T.; GALLER, J. R. Prenatal malnutrition and development of the brain. Neuroscience and Behavioral Reviews, New York, v. 17, p. 91128, 1993.

MORGANE, P. J.; MOKLER, D.J.; GALLER, J. R. Effects of prenatal malnutrition on the hippocampal formation. Neuroscience and Behavioral Reviews, New York, v. 26, p. 471483, 2002.

MURTHA, S.; PAPPAS, B. A.; RAMAN, S. Neonatal and adult forebrain norepinephrine depletion and the behavioral and cortical thickening effects of enriched/impoverished environment. Behavioral Brain Research, Amsterdam, v. 39, p. 249-261, 1990

NAKAGAWA, E. Acquired equivalence of cues in learning a matching-to-sample task by rats. The Psychological Record, Ohio, v.51, p. 453-472, 2001.

NIGROSH, B. J.; SLOTNICK, B. M.; NEVIN, J. A. Olfactory Discrimination, Reversal Learning and Stimulus Control in Rats. Journal of Comparative and Physiological Psychology, Whashington, v. 89. n. 4, 285 - 294, 1975.

NISSANI, M.; HOEFLER-NISSANI, D.; TINLAY, U.; HTUN, W. Simultaneous visual discrimination in Asian elephants. Journal of the experimental analysis of behavior, Bloomington, v. 83, p.15-29, 2005.

NORTH, A. J. Improvement in successive discrimination reversals. Journal of Comparative and Physiological Psychology, Washington, v. 43, 442 - 460, 1950.

O’GRADY, R. S.; JENNING, J. W. Reversal learning and transfer with rats using visual and olfactory cues. The Psychological Record, Granville, v. 24, 243 - 251, 1974.

PELLEGRINI, D. L. F.; NICOLA, D. C. P.; DE OLIVEIRA, L. M. Alterações neuromotoras e comportamentais em animais desnutridos: comparação entre modelos de desnutrição. Hispeci \& Lema, Bebedouro, v.7, 2003.

PEREIRA DA SILVA. M. S. P.; DE OLIVEIRA, L. M. Desnutrição e níveis de aminas biogênicas no sistema nervoso central. Nutrire, São Paulo, n. 29, p.75-97, 2005. 
PUURUNEN, K.; KOISTINAHO, J.; SIRVIO, J.; JOLKKONEM, J.; SIVENIUS, J. Enriched-environment housing increases neuronal fos-staining in the dentate gyrus after a water maze spatial learning task. Neuropharmacology, New York, v. 40, p. 440-447, 2001.

PRUSKY, G. T.; HARKER, K. T.; DOUGLAS, R. M.; WHISHAM, J. Q. Variation in visual acuity within pigmental and between pigmented and albino rat strains. Behavioral Brain Research, Amsterdam, v. 15, p. 339-48, 2002.

REEVES, P. G.; NIELSEN, F. H.; FAHEY Jr., G.C. AIN-93. Purified diets for laboratory rodents: final report of the American Institute of Nutrition ad hoc committee on the reformulation of the AIN-76 rodent diet. The Journal of Nutrition, Philadelphia, v. 123, p.1939-1951, 1993.

RENNER, J. M..; ROSENZWEIG, M. R. In: Enriched and impoverished environments: effects on brain and behavior, New York, Springer-Verlag, 1987

RIUL, T. R. ; ALMEIDA, P. S.; CARVALHO, A. F.; ALMEIDA, S. S.; DE OLIVEIRA, L.M. Effects of different levels of protein and environmental stimulation on the behavior of young rats tested in the elevated plus-maze. Nutritional Neuroscience, London, v. 1, p.295303, 1998.

RIUL, T. R.; CARVALHO, A. F.; ALMEIDA, P. S.; DE OLIVEIRA, L. M.; ALMEIDA, S. S. Ethological analysis of mother pup interactions in malnourished rats exposed to environmental stimulation. Brazilian Journal of Medical and Biological Research, Ribeirão Preto, v. 32, p.975-983, 1999.

ROCINHOLI, L. F.; ALMEIDA, P. S.; DE OLIVEIRA, L. M. Response thresholds to aversive stimuli in stimulated early protein-malnourished rats. Brazilian Journal of Medical and Biological Research, Ribeirão Preto, v. 30, p. 407-413, 1997.

ROCINHOLI, L.F.; L. M. DE OLIVEIRA.; J. F. COLAFÊMINA. Malnutrition and Environmental Stimulation in rats: wave latencies of the Brainstem Auditory Evoked Potentials. Nutritional Neuroscience, London, v. 4, p.199-212, a, 2001.

ROCINHOLI, L.F.; L.M. DE OLIVEIRA .; J.F. COLAFÊMINA. Malnutrition and Environmental Stimulation in Rats: interpeak intervals of the Brainstem Auditory Evoked Potentials. Nutritional Neuroscience, London, v. 4, p. 189-198, b, 2001.

ROSENZWEIG, M. R.; BENNETT, E. L. Effects of environmental enrichment and impoverishment on learning and on brain values in rodents. In: Oliveiro, A. (Ed) Genetics, Environment and intelligence. Amsterdam: Elsevier North-Holland, 1977, p. 163- 196. 
ROSENZWEIG, M. R.; LOVE, W.; BENNETT, E. L. Effects of a few hours a day of enriched experience on brain chemistry and brain weights. Physiology \& Behavior, Oxford, v. 3, p. 819-825, 1968.

SALAS, M.; CINTRA. L. Undernutrition and novelty responses influence of early food restriction on the responsiveness to novel stimuli in adult rats. Boletin de Estudies Medicos y Biologicos, México, v.30, p.201-204, 1979.

SANTUCCI, L. B.; DAUD, M. M .; ALMEIDA, S. S. ; DE OLIVEIRA, L. M . Effects of early protein malnutrition and environmental stimulation upon the reactivity to diazepam in two animal models of anxiety. Pharmacology, Biochemisty and Behavior, New York, v. 49, n. 1, p.393-398, 1994.

SCHUSTERMAN, R. J.; KASTAK, D. A california sea lion (Zalophus Californianus) is capable of forming equivalence relations. The Psychological Record, Ohio, v. 43, p. 823839, 1993.

SHAMBERG, S. M.; FIELD, T. M. Sensory deprivation stress and supplemental stimulation in the rat pup and preterm human neonate. Child Development, Malden, v. 58, p. 1431-1447, 1987.

SIDMAN, M. In: Equivalence relations and behavior: a research story. Boston: Authors Cooperative, 1994. 606 p.

SIDMAN, M.; TAILBY, W. Conditional discriminations. Matching-to-sample: an expansion of the testing paradigm. Journal of the Experimental Analysis of Behavior, Bloomington, v. 37. p. 5-32, 1982.

SKINNER, B. F. Science and human behavior. New York, 1953.

SMART, J. L. Reversal of spatial discrimination learning in a water maze by previously undernourished rats. Animal Learning Behavior, Austin, v. 4, n. 3, p. 313-316, 1976.

SMART, J. L. Early life malnutrition and later learning ability. A critical analysis. In: Genetics, environment and intelligence. In: Oliverio, A. (Ed.) Elsevier, Most. Holland. Biomedical Press, 1977. p. 215-235.

SMART, J. L.; WHATSON, T. S.; DOBBING, J. Thresholds of response to electric shock in previously undernourished rats. The British Journal of Nutrition, Wallington, v. 34, p. 511 -516, 1975. 
SWANSON, H. H. ; MCCONELL, P.; UYLINGS, H. B. M.; VAN OYEN, H. G.; VAN DE POLL, N. E. Interaction between pre-weaning undernutrition and post-weaning environmental on somatic development and behavior in male and female rats. Behavioural Processes, Amsterdam, v. 8, p. 1-20, 1983.

TERRACE H. S. Errorless transfer of a discrimination across two continua. Journal of the Experimental Analysis of Behavior, Bloomington, v. 6, 223-232, 1963.

TOMONAGA, M. Test for control by exclusion and negative stimulus relations of arbitrary matching to sample in a symmetry-emergent chimpanzee. Journal of the Experimental Analysis of Behavior, Bloomington, v.59, p. 215-229, 1993.

TOMONAGA, M..; MATSUZAWA, T,; FUJITA, K.; YAMAMOTO, J. Emergence of symmetry in a visual conditional discrimination by chimpanzees (Pan troglodytes) Psychological Reports, Louisville, v.68, p. 51-60, 1991.

TONKISS, J; STEPHENS, D. N. Rats undernourished as infants differ from controls in learning about a compound but not a simple discriminative stimulus. Physiology \& Behavior, Oxford, v. 26, p. 803-808, 1981.

TONKISS, J.; GALLER, J. R.; SHULDTT-HALE, B.; ROCCO, F. J. Prenatal protein malnutrition impairs visual discrimination learning in adult rats. Psychobiology, v. 19, n.3, p. 247-250, 1991.

VAUGHAN, W. Formation of equivalence sets in pigeons. Journal of Experimental Psychology, Washington, v. 14, p. 36-42, 1988.

VARTY, G. B.; PAULUS, M. P; BRAFF, D. L; GEYER. M. A. Environment enrichment and isolation rearing in the rat: effects on locomotor behavior and startle response plasticity. Biological Psychiatry, New York, v. 47, p. 864-873, 2000

VERSTYNEN, T.; TIERNEY, R. URBANSKI, T.; TANG, A. Neonatal novelty exposure modulates hippocampal volumetric asymmetry in the rat. Neuro Report, Londres, v. 12, p.3019-3022, 2001.

WIGGINS, R. C.; FULLER, G.; ENNA, S. J. Undernutrition and the development of brain neurotransmitter systems. Life Sciences, Oxford, v. 35, n. 20, p. 2085-2094, 1984.

WILSON, D. A.; WILLNER, J.; KURZ. E. M.; NADEL, L. Early handling increases hippocampal long-term potentiation in young rats. Behavioral Brain Research, Amsterdam, 
v.21. p. 223-227, 1986.

ZENTALL, T. R.; URCUIOLI, P. J. Emergent relations in the formation of stimulus classes by pigeons. The Psychological Record, Granville, v. 43, p. 795-810, 1993.

ZIMMERMAN, R. R. Behavioral deficiencies in protein-deprived monkeys In: Nutrition and Mental Functions. New York: George Serbian, 1975, p. 33-61. 